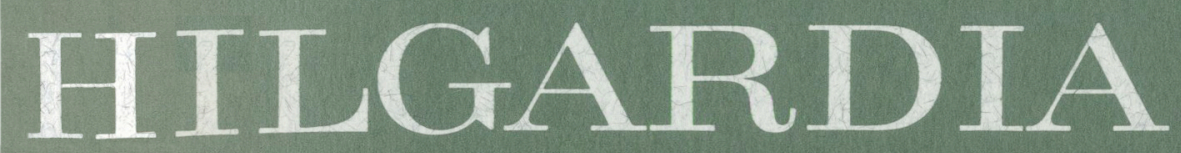

JOURNAL OF AGRICULTURAL SCIENCE PUBLISHED BY CALIFORNIA AGRICULTURALEXPERIMENTSTATION

Volume 34, Number 1 J January, 1963

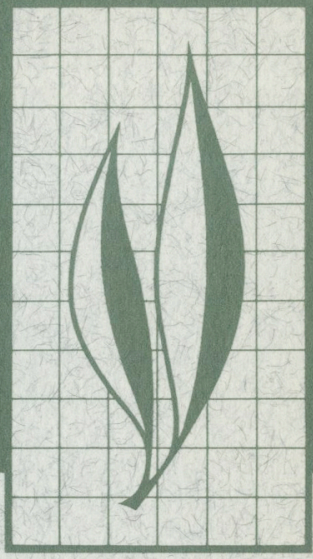

\title{
Chemical and Sensory Variability in Table Grapes
}

K. E. Nelson, G. A. Baker, A. J. Winkler

M. A. Amerine, H. B. Richardson, and Frances R. Jones 


\section{Chemical and Sensory Variability in Table Grapes ${ }^{1}$}

\section{INTRODUCTION}

Consumer ACCEPTANCE of grapes is based on a number of factors, including color, flavor, size, bloom, and texture. This study is concerned directly with the first two factors only, although textural changes associated with the maturity level of the fruit could possibly influence over-all sensory impressions. Flavor is defined as the complex reaction of taste and olfactory receptors; the olfactory aspect is believed to be secondary with non-muscat varieties. In this study, only the taste aspect of flavor will be considered.

There are four possible tastes in grapes: acidness (tart, or sour), sweetness, saltiness, and bitterness. White grapes are very low in tannins and other bitter-tasting substances. Red grapes have more bitter-tasting substances, but these are mainly in the skins and unless skins are vigorously chewed little bitter taste is experienced. Grapes have very little salty taste, though tartrates give a reaction. Tartrates as buffer agents repressing the ionization of malic and tartaric acids may, however, influence the acid taste.

The characteristic gustatory sensation of grapes is their sweet-sour taste. The main sugars found in grapes, levulose and dextrose, are of very unequal sweetness (about 1.5:1) and presumably the ratio as well as the total amount of the two may be of importance to the sweet taste (Amerine and Thoukis, 1958). ${ }^{2}$ The acid taste is produced by the organic acids, chiefly tartaric and malic, whose relative as well as total amounts in the fruit are influenced by the variety and by the temperature during the ripening period; these acids are of unequal sourness. For a discussion of the effect of variety, region, and time of maturity on the tartrate/malate ratio see Amerine and Winkler (1942).

Color is particularly significant as an acceptability factor in table grapes as it is the primary factor of the grapes' appearance, and appearance is of prime importance. In fact, color is usually used as an index of maturity in red and black grapes (United States Code of Federal Regulations, 1962). Its significance in white grapes is much less clearly defined, however. The subtle changes in color from grass-green to yellowish-amber as maturity advances are much less pronounced than with pigmented fruit, but there are strong indications that consumers do detect these color differences, associating the yellow tones with greater sweetness. The importance of the other appearance factors-size and shape of berry, amount of bloom, etc., have not been investigated thus far. It would also be desirable to have information on the importance to

${ }^{1}$ Submitted for publication July 20, 1962.

"See "Literature Cited" for citations referred to in the text by author and date. 
the consumer of size and shape of cluster, seedlessness versus non-seedlessness, degree of adherence of the berries to the pedicels, etc. Kinesthetic factors associated with erispness, juiciness, ete., also need to be studied.

All of the foregoing factors influence judgment as to when a grape can be considered mature. Although there are wide differences of opinion as to what constitutes maturity in table grapes, generally speaking a table grape is mature when it can be viewed and eaten with satisfaction. To date, it has been a major problem to determine maturity accurately without first eating the fruit. This difficulty is largely due to the fact that the ripening process in grapes involves a series of changes, such as an increase in color, sugar and $\mathrm{pH}$, and a decrease in titratable acidity, etc. These changes continue to take place as long as the grapes remain on the vine. The mature stage, therefore, is neither absolute nor does it represent the end product in the changes taking place in the berries. Thus, a grape can be said to be mature only when changes in color and other constituents have reached the point where their combined effect best suits taste and appearance requirements. This definition of maturity is indefinite, but it does point up the importance of various constituents of the berries as well as the difficulties of measuring maturity accurately. These difficulties are further complicated by the influence of level of crop, temperature during the ripening period and other factors influencing rates of change of the various constituents. Finally, there are interrelationships of sugar and acid tastes which may modify the over-all impression.

Standards of maturity are vitally important in the successful marketing of grapes. Such standards not only reduce the possibility of unacceptable fruit reaching the consumer, but also delineate recognizable levels of quality - and with increasing emphasis being placed on well-standardized products in the modern marketing system it is apparent that clearly defined standards of maturity for table grapes are required. Accurate methods of measuring maturity are, obviously, prerequisite to such standards.

Early maturity studies with table grapes in California emphasized the ralue of the degree Balling or Brix as a measure of maturity (Bioletti, 1925). Since most of the soluble solids in grapes are sugars the degree Balling is a fairly effective way of expressing sugar content, especially for riper grapes where proportion of sugar is higher. Legal recognition was given this method in the California Fruit, Nut and Vegetable Standardization Act of 1915 (California Laws and Statutes, 1915). Although this method of measuring the soluble solids content of the juice was effective, in practice it often proved unsatisfactory because it did not allow for the enormous significance of the acid content of the grapes as a taste factor. When grapes ripened under relatively cool conditions they would be unacceptably sour at the minimum degree Balling established, owing to the high acid content; when hot weather prevailed during ripening, the fruit would be quite palatable at the same degree Balling-but with a lower acid content. This fluctuation in acid content definitely limits the degree Balling alone as a measure of palatability.

Since palatability is believed to be a function of both the sour and sweet taste, the possibility of combining both soluble solids and acid content into a more satisfactory index of maturity was investigated. From these studies (Winkler, 1932) the Balling/acid ratio was proposed as a more reliable index of

\footnotetext{
${ }^{3}$ The degree Balling is very nearly equivalent to the degree Brix. Food technologists generally prefer the degree Brix and hydrometers are calibrated in degrees Brix. However, since the degree Balling is so much better known to the table grape industry, we will use it here in preference to degree Brix.
} 
palatability; this is the ratio of parts soluble solids (the degree Balling-for practical purposes mostly sugar) to parts titratable acid (expressed as grams tartaric acid per 100 milliliters of juice). This method has gained wide acceptance abroad (Dalmasso and Venezia, 1937; Hughes and Bouffard, 1937; and Nedelcher and Kondarev, 1934).

The Balling/acid ratio has had only limited acceptance for grapes in California (California Laws and Statutes, $1959 b$ ). Effective use has been made of the Brix/acid ratio by the citrus juice industry (Bell, 1955; Morse, 1954); state standards of quality for citrus juices are partially based on the Brix/ acid ratio (Florida Laws and Statutes, 1949, 1961; California Laws and Statutes, 1959a). Kilburn (1958) reports that citrus technologists with considerable experience in tasting juice find the ratio a useful descriptive term; he also notes that the tartness is inversely proportional to the ratio. Kilburn recommends the measurement of $\mathrm{pH}$ which is closely related to tartness in citrus juices. No such direct relationship with $\mathrm{pH}$ has yet been found for grapes, but Kilburn has suggested that there may be a relationship between the Brix/acid ratio and the $\mathrm{pH}$ (with three samples of grapes a common regression line did appear to exist).

In order to use a minimum Balling/ acid ratio as a quality standard for table grapes, data on the normal variation in the ratio must first be collected. That this would require a very large amount of data is indicated by the data required to set up the Florida citrus standards (Westbrook and Stenstrom, 1956, 1957). In order to evaluate its application, the ratio would undoubtedly have to be related to taste acceptability over a wide range of maturity levels of several varieties grown in different climatic regions of the state. Further, it should be tested for several years to ascertain its reliability with seasonal differences in ripening conditions-that is, the hot "low acid" and cool "high acid" years.
The objectives of the present study were to:

1. Develop methods for harvesting, handling and preparing grape samples for acceptability tests.

2. Determine methods for conducting acceptability tests-panel size, frequency of testing samples, number of samples at one sitting, lighting conditions and method of scoring.

3. Determine the relationship of maturity to palatability.

4. Determine the relationship of color to acceptability.

5. Determine the most satisfactory index of maturity.

\section{MATERIALS AND METHODS}

\section{Sampling, 1959}

During 1959, samples of Perlette, Cardinal, Thompson Seedless, Ribier and Tokay grapes were harvested starting with the first three from the Coachella Valley in June, followed by all of the varieties except Tokay from the lower San Joaquin Valley during July and August, and Tokay from the upper San Joaquin during August and September. For each variety from the San Joaquin Valley a second sample within the same Balling range was harvested 9 to 13 days after the first from the same or an adjacent vineyard. However, the acidity of the second sample was lower owing to longer exposure to elerated temperatures on the vine-and hence this sample had a higher Balling/ acid ratio.

Four levels of degree Balling were selected, from $1^{\circ}$ below the minimum standard to $2^{\circ}$ above. These levels were characterized as green (G), medium ripe $(M)$, ripe $(R)$, and very ripe (VR). A hand refractometer calibrated to $0.1^{\circ}$ Balling was used to determine maturity in the field. The instrument was checked frequently with distilled water to correct for changes in temperature. Each cluster of grapes was selected and classified into the appropriate degree Balling level on the basis of the 
average of three to six single-berry determinations. A portable ice-refrigerated precooler was available so that samples could be placed at optimum precooling conditions within 15 minutes after harvest, cooled to $40^{\circ} \mathrm{F}$ within 4 hours, and kept at $32^{\circ}$ to $35^{\circ} \mathrm{F}$ and 90 per cent relative humidity until used.

At Davis, a portion of each sample was prepared for analysis each day from the $3 \mathrm{rd}$ to 7 th day after harvest. Normal, sound berries of uniform size were cut from the stem at the base of the pedicel. Half of each Balling level was used for chemical and half for sensorv analysis. Five to ten berries at each level were presented simultaneously to each panel member for color and taste evaluation between 10 and 12 o'clock A.M. The four levels, each in a paper cup, were coded and sequence of presentation was varied each time. Taste ratings were usually done under red as well as white light to ascertain whether visual impressions of color influenced taste judgment. Each panel member was asked to evaluate color on a four-point hedonic scale: unattractive $=1$; not unattractive $=2 ;$ moderately attractive $=$ 3 ; and highly attractive $=4$. For taste, the scale included five points: dislike = 1 ; neither like nor dislike $=2$; like slightly $=3$; like moderately $=4$; and like extremely $=5$. As used, these scales were approximately linear on an overall basis.

\section{Sampling, 1960}

During 1960 the study was continued in the same manner except that only three levels of maturity were harvested - that is, from $1^{\circ}$ Balling below the minimum standard to $1^{\circ}$ above. The variety Ribier was not included and all taste tests were done under white light only.

\section{Sampling, 1961}

During 1961 two samplings of Perlette were made in the Coachella Valley in May, two of Cardinal in May and June, and two of Thompson Seedless in June; the sequence was repeated in the San Joaquin Valley during July and $\Lambda$ ugust. The two samplings of each variety were from the same or adjacent vineyards and were spaced 7 to 14 days apart-far enough apart that the acid content of the grapes usually had dropped appreciably before the second sampling. Water loss from the fruit was minimized in order to present the sensory panel members with both samplings simultaneously without texture differences from shrinkage. To do this, the grapes were placed in polyethylenelined lugs when picked. During precooling the liners were left open to prevent moisture condensation in the container. As soon as the fruit temperature reached $40^{\circ} \mathrm{F}$ (within 4 hours) the grapes were covered by the liner (but not sealed in) to minimize further water loss from excessive air movement. In this way, grapes harvested 2 weeks apart could be compared directly for as long as 2 weeks with no detectable differences (berry softness or stem drying) in texture.

\section{Preparation of samples}

Sample variability was a major problem during 1959 and 1960 as a result of the wide variation in degree Balling among the berries in each cluster-often as much as 6 degrees. Variability was drastically reduced by separating berries into maturity levels on the basis of specific gravity-a principle which is applied in separating fresh peas into maturity grades with sodium chloride solutions (United States Code of Federal Regulations, 1959). Sucrose was used in this study as it was thought that any residual sugar left on the berries would be less of an interference factor during tasting than salt would be. Also, since the degree Balling scale is based on sucrose solutions it was convenient to relate the degree Balling of the solution directly to that of the grapes. The samples of berries eut from the stems were first warmed quickly to $20^{\circ} \mathrm{C}$ in water, then placed in a sucrose solution of $19.5^{\circ}$ 
Balling at the same temperature. Those berries that sank were discarded as overmature, and those that floated were transferred to a solution of $18.5^{\circ}$ Balling. Those that sank were designated 19० Balling: those that floated were transferred to the next lower solution at $17.5^{\circ}$ Balling where the submerged fraction was recovered as $18^{\circ}$ Balling fruit. In this way, six lerels of maturity were obtained. The concentration of the solutions was adjusted frequently to keep the degree Balling within 0.3 of the stated level.

The above operation was done the day before the grapes were to be evaluated. Residual sugar solution was left on the berries when they were returned to storage within 2 hours after being segregated; washing was deferred to prevent berries from imbibing water and splitting from turgor pressure. One hour before evaluation the cold fruit was brought to room temperature with water which also remored practically all of the residual sucrose solution. Part of each sample was reserved for chemical analysis.

\section{Total acid determination in individual berries}

In the sample variability studies the total acid content of individual berries was determined using a modification of the method of Guymon and Ough (1962). Each berry was weighed to the nearest milligram then macerated in a Waring blender with 100 milliliters of distilled water. Just prior to the addition of the fruit this water had been boiled to expel dissolved carbon dioxide and the $\mathrm{pH}$ adjusted to phenolphthalein end point. During maceration and titration a blanket of nitrogen was maintained over the solution to exclude carbon dioxide. The acid content was expressed as grams tartaric acid per 100 grams of fruit.

\section{Sensory testing procedure}

The panel for the sensory tests was composed of university employees and their wives from various departments on the campus. Eighty per cent were men and 20 per cent were women; ages ranged from 20 to 65 years. No more than three of the members had had previous experience in table-grape tasting, and orientation of the panel members was limited to brief instructions on how to proceed, and how to complete the sensory ballot.

Each varietal pair of samplings was evaluated by a minimum of 25 panel members on 7 to 10 different days. Each day each panel member evaluated six maturity levels of each of the two samplings. Two to four berries constituted a sample at each level and only one level was presented to the panel member at a time for color and taste acceptability. The same four-point hedonic scale for color and five-point seale for taste was used.

A special sensory panel composed of 235 people who attended Grape Day in August, 1961 was used to evaluate the Thompson Seedless samples. These people were largely grape growers, grape servicing industry representatives, grape plant managers, and agricultural news reporters. All but one were men, and ages ranged upwards from 18 years. For this test each panel member evaluated each sample only once.

\section{RESULTS}

\section{Chemical composition of samples, 1959}

Table 1 shows the variety and chemical composition of grapes used in the taste and color acceptability tests. The maturity range of each variety, as determined in the laboratory with composite samples of fruit, was higher than predicted on the basis of refractometer determinations of fruit picked in the vineyard. The lowest maturity level (green) for Perlette, Cardinal and Ribier should have been $15^{\circ}$ Balling (one degree below the minimum standard), and for Thompson Seedless and Tokay in the San Joaquin Valley it should have been $17^{\circ}$ Balling. Also, 
TABLE 1

VARIETY AND CHEMICAL COMPOSITION OF TABLE GRAPES USED FOR TASTE AND COLOR ACCEPTABILITY TESTS, $1959^{*}$

\begin{tabular}{|c|c|c|c|c|c|}
\hline Variety & $\begin{array}{l}\text { Maturity } \\
\text { level }\end{array}$ & $\mathrm{pH}$ & $\begin{array}{l}\text { Balling } \\
\text { (degrees) }\end{array}$ & $\begin{array}{c}\text { Total acid } \\
\text { gm tart } / 100 \mathrm{ml}\end{array}$ & $\begin{array}{c}\text { Jalling/acid } \\
\text { ratio }\end{array}$ \\
\hline Perlette............. & Green & 3.16 & 15.9 & 0.81 & $19.6: 1$ \\
\hline Perlette...... & Medium ripe & 3.19 & 16.8 & 0.80 & $21.0: 1$ \\
\hline Perlette . . . . . . . . . . . . & Ripe & 3.22 & 17.5 & 0.74 & $23.6: 1$ \\
\hline Perlette..... & Very ripe & 3.24 & 18.2 & 0.69 & $26.4: 1$ \\
\hline Cardinal. & Green & 3.31 & 16.3 & 0.66 & $24.8: 1$ \\
\hline Cardinal... & Medium ripe & 3.33 & 17.1 & 0.64 & $26.7: 1$ \\
\hline Cardinal... & Ripe & 3.35 & 17.7 & 0.61 & $29.1: 1$ \\
\hline Cardinal. ........... & Very ripe & 3.39 & 18.5 & 0.60 & $30.7: 1$ \\
\hline Thompson Seedless..... & Green & 3.30 & 17.1 & 0.74 & $23.2: 1$ \\
\hline Thompson Seedless.... & Medium ripe & 3.34 & 17.8 & 0.71 & $25.1: 1$ \\
\hline Thompson Seedless... & Ripe & 3.37 & 18.6 & 0.67 & $27.8: 1$ \\
\hline Thompson Seedless. . & Very ripe & 3.39 & 19.6 & 0.64 & $30.6: 1$ \\
\hline Ribier............ & Green & 3.55 & 15.9 & 0.52 & $30.6: 1$ \\
\hline Ribier...... & Medium ripe & 3.57 & 16.3 & 0.51 & $32.0: 1$ \\
\hline Ribier.... & IRipe & 3.60 & 17.0 & 0.51 & $33.3: 1$ \\
\hline Ribier...... & Very ripe & 3.64 & 18.0 & 0.48 & $37.1: 1$ \\
\hline Tokay ..... & Green & 3.31 & 17.1 & 0.62 & $27.6: 1$ \\
\hline Tokay..... & Medium ripe & 3.29 & 17.6 & 0.60 & $29.3: 1$ \\
\hline Tokay ..... & Ripe & 3.37 & 18.4 & 0.56 & $32.9: 1$ \\
\hline Tokay ....... & Very ripe & 3.37 & 18.9 & 0.54 & $35.0: 1$ \\
\hline
\end{tabular}

* An attempt was made to secure fruit within a maturity range of $1^{\circ}$ Balling below the minimum standard to $2^{\circ}$ Balling above. The minimum degree Balling standard in the San Joaquin Valley is 16 for Perlette, Cardinal and Ribier, and 18 for Thompson Seedless and Tokay.

there is only about a $2^{\circ}$ Balling range between the lowest and highest levels for each variety while a range of $3^{\circ}$ was intended. As a result, the maturity levels were only about two-thirds of a degree Balling apart. The range in Balling/acid ratios for each variety was about the same - a difference of about seven between the lowest and highest ratios. The Perlette samples had the lowest ratios in the over-all ratio scale. The ranges of Cardinal and Thompson Seedless overlapped somewhat on the upper end of the Perlette range and those for Ribier and Tokay were the highest, with practically no overlap.

\section{Individual taste scores}

Table 2 shows individual scores of Thompson Seedless samples tasted under red and white light, and shows that there is a close relationship beiween the scores and the level of maturity. Under red light, only tasters $17,22,24,35,45$, 51 , and 54 showed any reversal from the trend of increased scores with increased maturity. Of these, tasters 22 , 35,51 , and 54 showed a reversal of the
$R$ and VR'values-possibly an actual decrease in acceptability due to overripeness rather than reversals due to sample or taster variability. The trend of acceptability increasing with maturity was the same when the grapes were tasted under white light. Here also seven tasters $(6,13,17,18,26,47$, and $54)$ showed a reversal to the trend at two or three maturity levels.

Table 3 shows that the trend was the same in individual taste scores for Perlette and Cardinal grapes. For Perlette, only tasters 42 and 51 showed a reversal to the trend at levels below VR. Eight tasters rated VR below R-an indication that VR grapes were actually less acceptable to them than $\mathrm{R}$ fruit. The Cardinal grapes showed the same decrease in acceptability at the VR level. However, variability within the range was much higher than for the Perlettes. Ten tasters $(11,16,26,29,35,37,39$, 47,53 , and 55) showed a reversal of scores at the low and intermediate maturity levels. This greater variability for Cardinal as compared to Perlette and Thompson Seedless can probably be 
ascribed in part to the strong inverse relationship between berry size and degree Balling. Although small berries were not used, slight differenees in size of "normal-sized" berries aggravated the variability problem. Also, smaller berries had fewer seeds-a possible texture factor which would cause a taster

T.LBLE 2

TASTE SCORES OF THOMPSON SEEDLESS GRAPES AT FOUR LEVELS OF MATURITY; TASTED UNDER RED ANI) WHITE LIGHT, 1959*

\begin{tabular}{|c|c|c|c|c|c|c|c|c|c|c|}
\hline \multirow{3}{*}{ Taster } & \multicolumn{5}{|c|}{ Red light } & \multicolumn{5}{|c|}{ White light } \\
\hline & \multirow{2}{*}{$\begin{array}{c}\text { Number } \\
\text { of } \\
\text { samples }\end{array}$} & \multicolumn{4}{|c|}{ Maturity level } & \multirow{2}{*}{$\begin{array}{l}\text { Number } \\
\text { of } \\
\text { samples }\end{array}$} & \multicolumn{4}{|c|}{ Maturity level $\dagger$} \\
\hline & & G & $\mathrm{M}$ & $\mathrm{R}$ & $\mathrm{VR}$ & & $\mathrm{G}$ & $\mathbf{M}$ & $\mathbf{R}$ & VR \\
\hline 1. & 38 & 2,24 & 2.82 & 3.16 & 3.37 & 6 & 1.50 & 2.33 & 3.00 & 4.17 \\
\hline $2 \ldots \ldots \ldots$ & 12 & 3.00 & 3.75 & 3.92 & 4.25 & . & $\ldots$ & $\ldots$ & $\ldots$ & $\ldots$ \\
\hline $3 \ldots \ldots$ & 30 & 1.83 & 2.07 & 2.87 & 3.40 & 9 & 1.33 & 1.56 & 2.89 & 3.89 \\
\hline 4. & 41 & 2.41 & 2.71 & 2.93 & 3.10 & .. & $\ldots$ & $\ldots$ & $\ldots$ & $\ldots$ \\
\hline 5. & 42 & 3.17 & 3.50 & 3.81 & 3.86 & 7 & 2.57 & 3.43 & 3.71 & 4.86 \\
\hline$\ldots \ldots$ & 41 & 2.22 & 2.85 & 3.07 & 3.49 & 8 & 1.50 & 2.88 & 2.75 & 3.38 \\
\hline$\ldots$. & 23 & 2.26 & 2.48 & 3.13 & 3.17 & 5 & 1.40 & 2.40 & 2.60 & 3.60 \\
\hline$\ldots \ldots$ & 12 & 3.25 & 3.58 & 3.58 & 3.83 & $\ldots$ & $\ldots$ & $\ldots$ & $\ldots$ & $\ldots$ \\
\hline$\ldots \ldots$ & 41 & 3.44 & 3.66 & 3.83 & 4.15 & 9 & 2.44 & 3.44 & 3.78 & 4.33 \\
\hline $10 \ldots \ldots \ldots$ & 4 & 1.25 & 2.00 & 2.50 & 3.00 & . & $\ldots$ & $\ldots$ & $\ldots$ & $\ldots$ \\
\hline $11 \ldots \ldots \ldots$ & 20 & 1.70 & 2.15 & 2.60 & 2.75 & 10 & 1.20 & 2.10 & 2.60 & 3.30 \\
\hline $12 \ldots \ldots \ldots$ & 56 & 2.21 & 2.79 & 2.96 & 3.11 & 10 & 1.50 & 1.80 & 2.20 & 2.60 \\
\hline$\ldots \ldots$ & 7 & 1.00 & 1.57 & 3.00 & 4.00 & 7 & 2.29 & 1. 29 & 3.29 & 3.57 \\
\hline$\ldots \ldots$ & 7 & 1.71 & 2.00 & 3.00 & 3.29 & 8 & 1.00 & 1.75 & 1.88 & 2.50 \\
\hline$\ldots \ldots$ & 13 & 3.92 & 4.38 & 4.67 & 4.77 & . & $\ldots$ & $\ldots$ & $\ldots$ & $\ldots$ \\
\hline$\ldots \ldots$ & 34 & 2.53 & 2.97 & 3.71 & 3.85 & 6 & 2.83 & 3.50 & 3.67 & 4.50 \\
\hline 17. & 5 & 2.80 & 3.60 & 3.20 & 4.20 & 7 & 3.14 & 2.29 & 3.14 & 4.14 \\
\hline $18 \ldots \ldots \ldots$ & 6 & 1.50 & 2.83 & 3.17 & 3.67 & 7 & 2.00 & 2.29 & 3.00 & 2.14 \\
\hline $19 \ldots \ldots \ldots$ & 22 & 1.55 & 2.05 & 2.41 & 2.82 & 7 & 1.14 & 1.86 & 2.00 & 2.43 \\
\hline 20. & 55 & 2.22 & 2.62 & 2.89 & 3.02 & 9 & 1.33 & 1.89 & 3.44 & 3.56 \\
\hline$\ldots \ldots$ & 18 & 2.67 & 3.11 & 3.22 & 3.28 & .. & $\ldots$ & $\ldots$ & $\ldots$ & $\ldots$ \\
\hline 22 . & 36 & 2.17 & 2.36 & 2.81 & 2.72 & 6 & 1.17 & 1.83 & 2.83 & 3.00 \\
\hline 23. & 28 & 2.64 & 3.07 & 3.39 & 3.96 & .. & $\ldots$ & $\ldots$ & $\ldots$ & $\ldots$ \\
\hline 24. & 31 & 2.35 & 2.90 & 2.74 & 3.77 & $\ldots$ & $\ldots$ & $\ldots$ & $\ldots$ & $\ldots$ \\
\hline$\ldots$ & 19 & 147 & 2.11 & 2.63 & 3.32 & 5 & 1.80 & 2.20 & 2.00 & 4.40 \\
\hline$\ldots \ldots$ & 6 & 2.50 & 3.00 & 3.67 & 4.00 & .. & $\ldots$ & $\ldots$ & $\ldots$ & $\ldots$ \\
\hline$\ldots \ldots$ & 8 & 2.25 & 2.88 & 3.50 & 4.00 & .. & $\ldots$ & $\ldots$ & $\ldots$ & $\ldots$ \\
\hline $29 \ldots \ldots \ldots$ & 22 & 1.82 & 2.68 & 3.09 & 3.95 & .. & $\ldots$ & $\ldots$ & $\ldots$ & $\ldots$ \\
\hline$\ldots \ldots$ & 6 & 1.67 & 2.33 & 3.50 & 3.67 & 4 & 1.75 & 1.75 & 3.25 & 3.50 \\
\hline $32 \ldots \ldots \ldots$ & 18 & 2.22 & 3.22 & 3.72 & 4.11 & .. & $\ldots$ & $\ldots$ & $\ldots$ & $\ldots$ \\
\hline $34 \ldots \ldots \ldots$ & 5 & 4.00 & 4.40 & 4.40 & 5.00 & 5 & 4.00 & 4.20 & 4.60 & 5.00 \\
\hline $35 \ldots \ldots \ldots$ & 34 & 2.06 & 2.62 & 2.85 & 2.76 & .. & $\ldots$ & $\ldots$ & $\ldots$ & $\ldots$ \\
\hline $36 \ldots \ldots \ldots$ & 34 & 2.53 & 3.00 & 3.15 & 3.35 & 6 & 2.00 & 2.50 & 2.50 & 3.67 \\
\hline 38........ & 57 & 2.81 & 3.25 & 3.77 & 4.02 & 9 & 1.67 & 3.11 & 3.44 & 3.78 \\
\hline $39 \ldots \ldots \ldots$ & 30 & 2.07 & 2.63 & 3.07 & 3.13 & 10 & 1.80 & 3.20 & 3.50 & 3.60 \\
\hline $\mathbf{4 0} \ldots \ldots \ldots$ & 24 & 3.08 & 3.12 & 3.58 & 3.96 & .. & $\ldots$ & $\ldots$ & $\ldots$ & $\ldots$ \\
\hline 41. & 21 & 1.81 & 2.33 & 3.10 & 3.10 & 4 & 1.75 & 2.50 & 3.75 & 4.25 \\
\hline 42. & 50 & 2.92 & 3.52 & 3.54 & 3.88 & . & $\ldots$ & $\ldots$ & $\ldots$ & $\ldots$ \\
\hline 44. & 22 & 2.45 & 3.32 & 3.82 & 4.45 & .. & $\ldots$ & $\ldots$ & $\ldots$ & $\ldots$ \\
\hline 45. & 9 & 3.33 & 3.22 & 3.44 & 3.56 & .. & $\ldots$ & $\ldots$ & $\ldots$ & $\ldots$ \\
\hline 46. & 20 & 1.70 & 2.70 & 2.70 & 3.10 & & $\ldots$ & $\ldots$ & $\ldots$ & $\ldots$ \\
\hline $47 \ldots \ldots \ldots$ & 30 & 2.13 & 2.80 & 3.27 & 3.43 & 5 & 1.40 & 2.20 & 3.80 & 3.40 \\
\hline $48 \ldots \ldots \ldots$ & 51 & 2.84 & 3,16 & 3.47 & 3.65 & 8 & 2.88 & 3.00 & 3.50 & 3.88 \\
\hline 50. & .. & $\ldots$ & $\ldots$ & $\ldots$ & $\ldots$ & 4 & 2.75 & 3.25 & 3.25 & 4.25 \\
\hline 61. & $\ddot{8}$ & 1.75 & 2.75 & 3.75 & 3.50 & $\cdots$ & $\ldots$ & $\ldots$ & $\ldots$ & $\ldots$ \\
\hline 53. . & 44 & 1.59 & 1.93 & 2.36 & 2.77 & .. & $\ldots$ & $\ldots$ & $\ldots$ & $\ldots$ \\
\hline 54. & 5 & 3.20 & 3.40 & 4.00 & 3.80 & 5 & 3.40 & 3.80 & 3.60 & 4.00 \\
\hline $55 \ldots \ldots$ & 48 & 2.31 & 2.83 & 2.90 & 3.40 & .. & $\ldots$ & $\ldots$ & $\ldots$ & $\ldots$ \\
\hline $56 \ldots \ldots \ldots$ & 31 & 2,90 & 3.35 & 3.68 & 3.74 & .. & $\ldots$ & $\ldots$ & $\ldots$ & $\ldots$ \\
\hline
\end{tabular}

* Taste values are based on a hedonic scale of $:$ dislike $=1.00$; neither like nor dislike $=2.00$; like slightly $=3.00$; like moderately $=4.00$; like extremely $=5.00$

$\dagger \mathrm{G}=$ green; $\mathrm{M}=$ medium ripe $\mathrm{R}=$ ripe; $\mathrm{VR}=$ very ripe 
to discriminate against larger berries. Results shown in table 4 support the possibility that berry size introduces another variable; reversals are again numerous for Ribier and for Tokay, and in five instances (tasters 38 for Ribier and $2,9,33$, and 42 for Tokay) the score for the $V R$ level was lower than that for $G$.

Even ignoring the numerous reversals of scores in tables 2,3 , and 4 it is evi- dent that the tasters differed widely in the degree of acceptability for the fruit. For example, tasters 34 and 35 in table 3 showed wide differences for Perlettes. Taster 34 appeared to like the samples so well that even the score of the lowest maturity level was remarkably high. On the other hand taster 35 gave even the ripest sample a comparatively low score.

The tasters also appeared to differ widely in the magnitude of increase in

TABLE 3

TASTE SCORES OF PERLETTE AND CARDINAL GRAPES AT FOUR LEVELS OF MATURITY; TASTED UNDER RED LIGHT, 1959*

\begin{tabular}{|c|c|c|c|c|c|c|c|c|c|c|}
\hline \multirow{3}{*}{ Taster } & \multicolumn{5}{|c|}{ Perlette } & \multicolumn{5}{|c|}{ Cardinal } \\
\hline & \multirow{2}{*}{$\begin{array}{l}\text { Number } \\
\text { of } \\
\text { samples }\end{array}$} & \multicolumn{4}{|c|}{ Maturity level† } & \multirow{2}{*}{$\begin{array}{c}\text { Number } \\
\text { of } \\
\text { samples }\end{array}$} & \multicolumn{4}{|c|}{ Maturity level $\dagger$} \\
\hline & & $\mathrm{G}$ & M & $\mathrm{R}$ & VR & & $G$ & $\mathbf{M}$ & $R$ & VR \\
\hline $1 \ldots \ldots \ldots$ & 4 & 1.50 & 1.50 & 2.50 & 2.25 & 8 & 1.00 & 3.12 & 3.25 & 3.62 \\
\hline $2 \ldots \ldots \ldots$ & 11 & 2.09 & 2.55 & 3.09 & 3.36 & 10 & 2.30 & 2.90 & 3.30 & 3.60 \\
\hline $3 \ldots \ldots \ldots \ldots$ & 16 & 1.62 & 2.38 & 3.06 & 3.12 & 16 & 1.91 & 1.91 & 2.18 & 2.41 \\
\hline $4 \ldots \ldots \ldots \ldots$ & 11 & 2.09 & 2.36 & 2.73 & 2.64 & 20 & 2.95 & 3.25 & 3.60 & 3.45 \\
\hline $5 \ldots \ldots \ldots \ldots$ & 12 & 2.83 & 3.42 & 3,58 & 3.83 & . & $x$ & $\cdots$ & $\ldots$ & $\ldots$ \\
\hline $6 \ldots \ldots \ldots$ & 12 & 1.50 & 2.17 & 2.92 & 2.50 & . & $\ldots$ & $\ldots$ & $\ldots$ & $\ldots$ \\
\hline $7 \ldots \ldots \ldots$ & 14 & 2.21 & 2.79 & 3.36 & 3.57 & 14 & 2.79 & 3.07 & 3.36 & 3.93 \\
\hline $8 \ldots \ldots \ldots \ldots$ & . & $\ldots$ & $\ldots$ & $\ldots$ & $\ldots$ & 16 & 3.44 & 3.69 & 3.88 & 3.81 \\
\hline $9 \ldots \ldots \ldots$ & 12 & 2.25 & 2.75 & 2.83 & 3.08 & 12 & 3.08 & 3.58 & 3.58 & 4.00 \\
\hline $11 \ldots \ldots \ldots \ldots$ & 14 & 1.43 & 2.21 & 2.21 & 2.50 & 18 & 2.28 & 2.25 & 2.17 & 2.78 \\
\hline $12 \ldots \ldots \ldots \ldots$ & 16 & 1.44 & 1.50 & 2.06 & 2.25 & 20 & 1.75 & 2.30 & 2.35 & 2.65 \\
\hline $14 \ldots \ldots \ldots \ldots$ & 7 & 2.43 & 2.43 & 3.43 & 3.00 & 4 & 3.25 & 3.25 & 3.50 & 4.25 \\
\hline $16 \ldots \ldots \ldots \ldots$ & 5 & 2.20 & 3.40 & 4.40 & 4.60 & 18 & 2.28 & 3.22 & 3.28 & 3.06 \\
\hline $19 \ldots \ldots \ldots$ & 6 & 1.50 & 1.50 & 2.00 & 3.00 & 8 & 2.00 & 2.38 & 2.75 & 3.88 \\
\hline $20 \ldots \ldots \ldots \ldots$ & 15 & 2.00 & 2.60 & 2.67 & 3.07 & 20 & 2.45 & 2.50 & 3.25 & 3.50 \\
\hline $22 \ldots \ldots \ldots \ldots$ & 12 & 1.67 & 2.58 & 3.17 & 3.67 & 14 & 2.29 & 2.50 & 3.14 & 2.86 \\
\hline $23 \ldots \ldots \ldots \ldots$ & . & $\ldots$ & $\ldots$ & $\ldots$ & $\ldots$ & 4 & 2.50 & 2.75 & 4.25 & 4.50 \\
\hline $25 \ldots \ldots \ldots \ldots$ & .. & $\ldots$ & $\ldots$ & $\ldots$ & $\ldots$ & 8 & 1.75 & 2.38 & 2.75 & 3.00 \\
\hline $26 \ldots \ldots \ldots \ldots$ & 9 & 1.11 & 2.44 & 3.00 & 4.11 & 6 & 1.17 & 2.33 & 2.17 & 3.50 \\
\hline $29 \ldots \ldots \ldots \ldots$ & $\ldots$ & $\ldots$ & $\ldots$ & $\ldots$ & $\ldots$ & 5 & 2.40 & 3.80 & 3.20 & 3.60 \\
\hline $31 \ldots \ldots \ldots$ & 12 & 1.08 & 1.33 & 2.25 & 2.58 & 14 & 2.00 & 2.43 & 3.00 & 3.21 \\
\hline $32, \ldots \ldots \ldots$ & 8 & 2.38 & 2.50 & 3.50 & 3.75 & 20 & 1.75 & 3.35 & 3.40 & 4.05 \\
\hline $34 \ldots \ldots \ldots \ldots$ & 7 & 4.29 & 4.43 & 4.57 & 4.43 & .. & $\ldots$ & $\ldots$ & $\ldots$ & $\ldots$ \\
\hline $35 \ldots \ldots \ldots \ldots$ & 10 & 1.30 & 1.80 & 2.30 & 2.10 & 12 & 1.56 & 2.06 & 2,00 & 2.17 \\
\hline 36. & 16 & 2.38 & 2.81 & 3.19 & 3.56 & 22 & 2.45 & 3.45 & 3.59 & 3.82 \\
\hline $37 \ldots \ldots \ldots \ldots$ & $\cdots$ & $\ldots$ & $\ldots$ & $\ldots$ & $\ldots$ & 6 & 2.00 & 3.67 & 3.17 & 3.50 \\
\hline $38 \ldots \ldots \ldots \ldots$ & 17 & 1.82 & 2.47 & 3.47 & 3.47 & 22 & 2.32 & 2.95 & 3.55 & 3.95 \\
\hline $39 \ldots \ldots \ldots \ldots$ & 15 & 2.20 & 2.40 & 3.00 & 3.20 & 20 & 3.55 & 3.85 & 3.75 & 3.90 \\
\hline $40 \ldots \ldots \ldots \ldots$ & . & $\ldots$ & $\cdots$ & $\cdots$ & $\ldots$ & 4 & 3,50 & 3.50 & 4.75 & 3.25 \\
\hline $41 \ldots \ldots \ldots \ldots$ & 14 & 2.57 & 3.50 & 3.57 & 3.57 & 16 & 2.81 & 3.25 & 3.81 & 4.06 \\
\hline $42 \ldots \ldots \ldots \ldots$ & 5 & 1.20 & 2.60 & 2.40 & 3.80 & 18 & 1.78 & 2.06 & 2.61 & 3.17 \\
\hline $47 \ldots \ldots \ldots \ldots$ & 5 & 2.00 & 3.00 & 3.40 & 4.00 & 12 & 3.42 & 3.33 & 4.08 & 3.83 \\
\hline $48 \ldots \ldots \ldots \ldots$ & 15 & 2.47 & 3.07 & 3.60 & 3.80 & 22 & 3.14 & 4.00 & 4,18 & 4.23 \\
\hline $49 \ldots \ldots \ldots \ldots$ & 11 & 2.64 & 2.64 & 3.09 & 3.18 & 4 & 3.50 & 3.75 & 3.75 & 3.75 \\
\hline $50 \ldots \ldots \ldots \ldots$ & 10 & 2.10 & 3.90 & 4.30 & 4.30 & .. & $\ldots$ & $\ldots$ & $\ldots$ & $\ldots$ \\
\hline $51 \ldots \ldots \ldots$ & 12 & 3.25 & 3.08 & 3.58 & 3.92 & 8 & 3.25 & 3.75 & 3.88 & 4.12 \\
\hline $53 \ldots \ldots \ldots \ldots$ & 9 & 1.44 & 2.00 & 2.67 & 2,22 & 16 & 1.81 & 2.38 & 2.19 & 3.00 \\
\hline $54 \ldots \ldots \ldots \ldots$ & 12 & 3.25 & 3.58 & 4.08 & 4.00 & 12 & 3.33 & 3.92 & 4.17 & 4.42 \\
\hline $55 \ldots \ldots \ldots$ & .. & $\ldots$ & $\ldots$ & $\ldots$ & $\ldots$ & 8 & 3.25 & 3.62 & 3.25 & 3.62 \\
\hline $56 \ldots \ldots \ldots \ldots$ & 5 & 3.00 & 3.00 & 4.00 & 3.40 & 18 & 2.22 & 3.44 & 3.44 & 3.83 \\
\hline
\end{tabular}

* Taste values are based on a hedonic scale of: dislike $=1.00 ;$ neither like nor dislike $=2.00 ;$ like slightly $=3.00$; like moderately $=4.00$; like extremely $=5.00$

$\dagger \mathrm{G}=$ green; $\mathrm{M}=$ medium ripe; $\mathrm{R}=$ ripe; $\mathrm{VR}=$ very ripe. 
TABLe 4

TASTE SCORES OF RIBIER AND TOKAY GRAPES AT FOUR LEVELS OF MATURITY; TASTED UNDER RED LIGHT, 1959*

\begin{tabular}{|c|c|c|c|c|c|c|c|c|c|c|}
\hline \multirow{3}{*}{ Taster } & \multicolumn{5}{|c|}{ Ribier } & \multicolumn{5}{|c|}{ Tokay } \\
\hline & \multirow{2}{*}{$\begin{array}{l}\text { Number } \\
\text { of } \\
\text { samples }\end{array}$} & \multicolumn{4}{|c|}{ Maturity level $\dagger$} & \multirow{2}{*}{$\begin{array}{c}\text { Number } \\
\text { of } \\
\text { samples }\end{array}$} & \multicolumn{4}{|c|}{ Maturity level $\uparrow$} \\
\hline & & G & $M$ & $\mathrm{R}$ & $\mathrm{VR}$ & & $\mathrm{G}$ & $\mathbf{M}$ & $\mathrm{R}$ & $\mathrm{VR}$ \\
\hline $1 \ldots$ & 8 & 1.82 & 2.50 & 2.75 & 3.25 & 8 & 1.50 & 1.88 & 3.25 & 3.50 \\
\hline $2 \ldots$ & 6 & 2.00 & 3.00 & 3.50 & 3.83 & 6 & 3.33 & 3.00 & 4.00 & 3.33 \\
\hline $3 \ldots \ldots$ & 10 & 2.60 & 3.00 & 2.70 & 3.40 & 10 & 2.30 & 2.70 & 3.20 & 3.60 \\
\hline $4 \ldots \ldots$ & 8 & 3.00 & 3.12 & 3.25 & 3.38 & 8 & 3.38 & 3.50 & 3.62 & 3.88 \\
\hline $5 \ldots$ & 10 & 2.80 & 2.80 & 3.70 & 4.40 & 10 & 2.30 & 2.50 & 3.40 & 3.70 \\
\hline $6 . \ldots \ldots$ & 10 & 2.00 & 2.50 & 3.00 & 3.40 & 10 & 2.50 & 2.50 & 3.20 & 3.60 \\
\hline $7 \ldots \ldots$ & 4 & 2.25 & 2.50 & 2.75 & 3.75 & 4 & 3.25 & 3.25 & 4.25 & 4.25 \\
\hline 9. & 10 & 3.80 & 3.60 & 3.90 & 4.10 & 10 & 4.20 & 4.10 & 4.60 & 4.20 \\
\hline 12. & 8 & 2.38 & 2.50 & 2.62 & 2.88 & 8 & 1.50 & 2.00 & 2.38 & 2.12 \\
\hline $15 \ldots \ldots \ldots$ & 8 & 2.88 & 3.50 & 4.25 & 4.50 & 8 & 2.62 & 4.00 & 4.12 & 4.25 \\
\hline $16 \ldots \ldots \ldots$ & 6 & 2.00 & 2.67 & 3.00 & 2.00 & 6 & 2.33 & 3.33 & 3.33 & 4.00 \\
\hline $20 \ldots \ldots \ldots \ldots$ & 10 & 2.30 & 2.40 & 2.50 & 3.30 & 8 & 3.00 & 2.75 & 3.88 & 3.62 \\
\hline $22 \ldots \ldots \ldots \ldots$ & 6 & 2.00 & 2.50 & 2.83 & 3.50 & 6 & 1.50 & 1.83 & 2.67 & 2.33 \\
\hline 23. & 4 & 2.75 & 3.00 & 3.75 & 5.00 & 4 & 2.25 & 2.00 & 3.25 & 3.50 \\
\hline $24 \ldots \ldots \ldots \ldots$ & 6 & 2.50 & 2.00 & 3.00 & 3.83 & 6 & 2.00 & 1.83 & 3.00 & 3.67 \\
\hline $29 \ldots \ldots \ldots$ & 4 & 3.75 & 4.00 & 4.50 & 4.00 & 4 & 2.25 & 3.50 & 3.25 & 4.50 \\
\hline $33 \ldots \ldots$ & 8 & 2.25 & 2.25 & 2.00 & 2.12 & 8 & 4.12 & 3.88 & 4.38 & 4.00 \\
\hline $35 \ldots \ldots$ & 8 & 1.62 & 1.75 & 1.75 & 2.12 & 8 & 2.75 & 3.00 & 2.75 & 3.88 \\
\hline 38. & 4 & 4.25 & 4.50 & 4.75 & 4.00 & 4 & 3.00 & 3.50 & 4.25 & 5.00 \\
\hline $41 \ldots \ldots$ & 4 & 2.25 & 3.25 & 3.25 & 4.00 & 4 & 1.75 & 2.50 & 2.75 & 2.75 \\
\hline $42 \ldots \ldots \ldots$ & 10 & 2.30 & 2.50 & 2.50 & 3.00 & 10 & 2.50 & 2.60 & 2.50 & 2.20 \\
\hline $44 \ldots \ldots$ & 6 & 1.67 & 1.83 & 2.17 & 3.33 & 6 & 1.83 & 2.00 & 2.67 & 3.00 \\
\hline $46 \ldots \ldots$ & 10 & 2.10 & 2.30 & 2.70 & 2.60 & 10 & 1.70 & 1.90 & 2.30 & 2.70 \\
\hline $48 \ldots \ldots \ldots \ldots$ & 8 & 3.50 & 3.62 & 4.25 & 4.00 & 8 & 3.12 & 3.50 & 3.25 & 3.75 \\
\hline $53 \ldots \ldots \ldots$ & 6 & 1.50 & 2.17 & 2.00 & 2.67 & 6 & 1.33 & 1.83 & 1.67 & 1.83 \\
\hline $55 \ldots \ldots \ldots$ & 10 & 2.10 & 2.70 & 2.90 & 3.10 & 10 & 2.50 & 2.60 & 3.40 & 3.50 \\
\hline $56 \ldots \ldots \ldots$ & 4 & 1.50 & 2.25 & 2.75 & 3.50 & 4 & 1.50 & 3.25 & 2.75 & 2.75 \\
\hline
\end{tabular}

- Taste values are based on a hedonic scale of : dislike $=1.00$; neither like nor dislike $=2.00 ;$ like slightly $=3.00$; like moderately $=4.00 ;$ like extremely $=5.00$

$f \mathrm{G}=$ green; $\mathrm{M}=$ medium ripe; $\mathrm{R}=$ ripe; $\mathrm{VR}=$ very ripe.

acceptability with maturity. For example, taster 8 in table 2 under red light showed a small but consistent increase in acceptability with maturity, whereas taster 13 showed an inerease of much greater magnitude.

\section{Weighted average taste and color scores}

Table 5 shows weighted average sensory scores. Taste trends for all of the varieties show a consistent increase in value as the maturity level rises with no reversals of scores. Whether Perlettes and Cardinals were tasted under red or white light appeared to make no difference in either the trend or magnitude of increase in taste scores. This seems to indicate that visual impressions of color in Perlette and Cardinal grapes do not affect the taste reaction. However, when Thompson Seedless grapes were tasted under white light the scores showed a greater increase in value over the maturity range than the increase in scores obtained under red light. While the score for the VR level under white light is only slightly higher than that obtained under red light, the scores at the lower maturity levels are considerably lower than are the corresponding values under red light. It is unexpected that a white grape such as Thompson Seedless would show this difference, particularly when one which is red-pigmented (such as Cardinal) does not. A partial explanation for this difference may be that the trend under white light was based on a much smaller number of tasters and samples than were trends 
TABLE 5

WEIGHTED AVERAGE SENSORY SCORES OF GRAPES AT FOUR LEVELS OF MATURITY*

\begin{tabular}{|c|c|c|c|c|c|c|c|c|}
\hline \multirow{2}{*}{ Variety } & \multirow{2}{*}{ Light } & \multirow{2}{*}{$\begin{array}{c}\text { Sensory } \\
\text { test }\end{array}$} & \multirow{2}{*}{$\begin{array}{c}\text { Number } \\
\text { of } \\
\text { judges }\end{array}$} & \multirow{2}{*}{$\begin{array}{l}\text { Number } \\
\text { of } \\
\text { samples }\end{array}$} & \multicolumn{4}{|c|}{ Maturity level $\dagger$} \\
\hline & & & & & $\mathrm{G}$ & $\mathrm{M}$ & $\mathrm{R}$ & $\mathrm{VR}$ \\
\hline Perlette........... & Red & Taste & 33 & 359 & 2.09 & 2.62 & 3.12 & 3.29 \\
\hline Perlette........... & White & Taste & 42 & 507 & 2.14 & 2.62 & 3.09 & 3.51 \\
\hline Perlette..... & White & Color & 42 & 509 & 2.39 & 2.45 & 2.42 & 2.46 \\
\hline Cardinal. & Red & Taste & 36 & 475 & 2.46 & 3.02 & 3.26 & 3.53 \\
\hline Cardinal. & White & Taste & 47 & 624 & 2.56 & 3.03 & 3.24 & 3.61 \\
\hline Cardinal......... & White & Color & 47 & 627 & 2.66 & 2.95 & 3.02 & 3.05 \\
\hline Thompson Seedless. . & Red & Taste & 48 & 1224 & 2.40 & 2.88 & 3.22 & 3.50 \\
\hline Thompson Seedless. . & White & Taste & 27 & 186 & 1.92 & 2.53 & 3.08 & 3.71 \\
\hline Thompson Seedless. . & White & Color & 39 & 495 & 2.45 & 2.64 & 2.64 & 2.64 \\
\hline Ribier........... & Red & Taste & 27 & 196 & 2.43 & 2.73 & 3.02 & 3.38 \\
\hline Tokay ............... & Red & Taste & 27 & 194 & 2.50 & 2.78 & 3.24 & 3.44 \\
\hline
\end{tabular}

${ }^{*}$ Taste values based on a hedonic scale of: dislike $=1.00$; neither like nor dislike $=2.00$; like slightly $=3.00 ;$ like moderately $=4.00 ;$ like extremely $=5.00$.

Color values based on a hedonic scale of : unattractive $=1.00$; not unattractive $=2.00$; moderately attractive $=3.00$; highly attractive $=4.00$.

$f \mathrm{G}=$ green; $\mathrm{M} \stackrel{4}{=}$ medium ripe; $\mathrm{R}=$ ripe: $\mathrm{VR}=$ very ripe

for Perlette and Cardinal grapes. If we adjust the red light tastings for Thompson Seedless to the same tasters in the same proportion as for white light, we get weighted averages of $2.23,2.73,3.22$, 3.50 corresponding to the previous averages of $2.40,2.88,3.22,3.50$ for red light tasting, and 1.92, 2.53, 3.08, 3.71 for the white light tastings (table 5); remaining discrepancies may be due to the smallness of the white light sample. The similarity of trends under red and white light lends considerable support to the reliability of the method of sensory analysis used.

The scores for color show very small, if any, increase with maturity. In fact there is a reversal of the $M$ and $R$ scores for Perlette which makes the very small increase from 2.39 at the $G$ level to 2.46 for VR questionable. There is no increase in the score beyond $M$ for Thompson Seedless so (for the white varieties at least) there is no definite relationship between color acceptability and maturity, with the exception of the lowest maturity level of Thompson Seedless. However, Cardinal scores show a consistent increase with maturity, indicating that color in pigmented grapes is a more pronounced index of maturity than for white grapes. The increase is large for the $\mathrm{G}$ and $\mathrm{M}$ levels but thereafter quite small. Unfortunately, no studies were made on Ribier and Tokay grapes to ascertain whether colormaturity relationship was consistent for these pigmented varieties.

The correlation coefficients between taste scores and color scores were 0.39 for Thompson Seedless, 0.32 for Perlette, and 0.35 for Cardinals; the coefficient for Thompson Seedless was based on all score sheets (1404), but the other coefficients were based on 500 score sheets each. These correlations bear out a general impression that tasting under white light is more consistent with chemical findings of maturity than is tasting under red light where no assessment of color can be made.

\section{Analysis of variance treatment}

The sensory-variety-maturity-judgeslight-relationships were explored further with three analyses of variance:

1. Tasting under red light with sixteen tasters. The panel was reduced to this number when data from tasters with less than six score sheets per variety were omitted. Included in this panel were tasters $2,3,4,7,9,11,12,20,22$, $35,36,38,39,41,48$, and 53 (table 2). Only Perlette, Cardinal and Thompson 


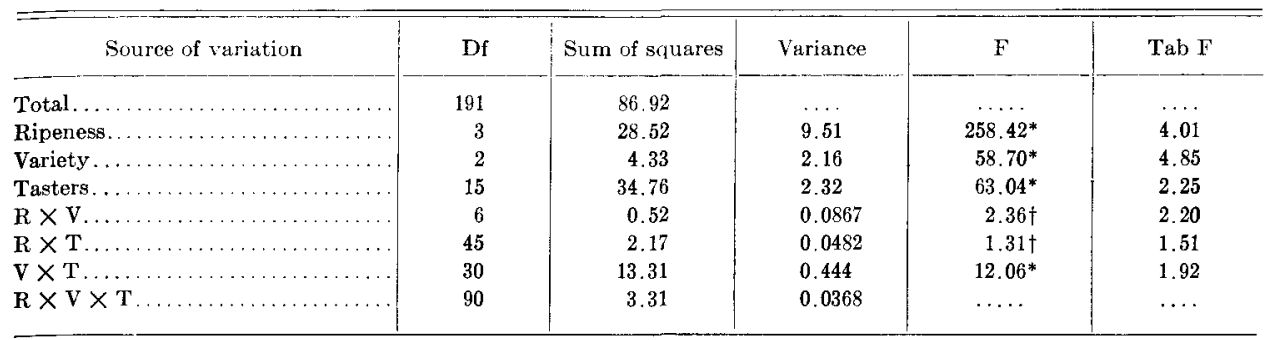

* Significant at the 1 per cent level.

$\dagger$ Significant at the 5 per cent level.

Seedless varieties were included in this statistical treatment. This analysis is not as precise as we would like because averages are based on varying numbers of score sheets, but since the analysis of variance is somewhat insensitive to such departures from the theoretical model the gross aspects of the analysis are indicative enough to be mentioned. The analysis is shown in the table at top of this page.

Under red light, taste scores showed significant differences between degrees of ripeness, varieties of grapes and tasters. Also, there was a highly significant interaction between varieties and tasters.

2. Tasting under red and white light with seven tasters. Only seven panel members completed six or more taste score sheets on Perlette, Cardinal and Thompson Seedless grapes under both red and white light. They were tasters $3,9,11,12,20,38$, and 39 (table 2 ). The analysis is shown below, top.

In this analysis of variance, which includes seven tasters, red and white light, four degrees of ripeness and three varieties of grapes, large differences were found due to tasters,

\begin{tabular}{|c|c|c|c|c|c|}
\hline Source of variation & Df & Sum of squares & Variance & $\mathrm{F}$ & Tab F \\
\hline Total.......... & 167 & 93.21 & $\ldots$ & $\ldots \ldots$ & $\ldots$ \\
\hline Tasters....... & 6 & 31.60 & 5.27 & $76.38^{*}$ & 2.99 \\
\hline Variety. . & 2 & 3.40 & 1.70 & $24.64^{*}$ & 4.82 \\
\hline Ripeness... & 3 & 35.79 & 11.93 & $172.90^{*}$ & 3.98 \\
\hline Light. . . . . & 1 & 0.040 & 0.040 & $0.58 \dagger$ & 3.94 \\
\hline $\mathbf{T} \times \mathbf{V} \ldots$ & 12 & 6.41 & 0.53 & $7.68^{*}$ & 2.36 \\
\hline $\mathbf{T} \times \mathbf{R}$. & 18 & 3.46 & 0.19 & $2.75^{*}$ & 2.12 \\
\hline $\mathrm{T} \times \mathrm{L} \ldots$ & 6 & 1.33 & 0.22 & $3.19^{*}$ & 2.99 \\
\hline$V \times R \ldots$ & 6 & 1.74 & 0.29 & $4.20^{*}$ & 2.99 \\
\hline $\mathrm{V} \times \mathrm{L} \ldots$ & 2 & 1.26 & 0.63 & $9.13^{*}$ & 4.82 \\
\hline$R \times \mathbf{L} \ldots \ldots$ & 3 & 0.75 & 0.25 & $3.62 \dagger$ & 2.70 \\
\hline Remainder... & 108 & 7.43 & 0.069 & $\ldots \ldots$ & $\ldots$ \\
\hline
\end{tabular}

* Significant at the 1 per cent level.

$\dagger$ Significant at the 5 per cent level.

\begin{tabular}{|c|c|c|c|c|c|}
\hline Source of variation & $\mathbf{D f}$ & Sum of squares & Variance & $\mathrm{F}$ & Tab F \\
\hline 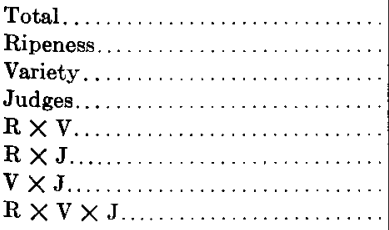 & $\begin{array}{r}83 \\
3 \\
2 \\
6 \\
6 \\
18 \\
12 \\
36\end{array}$ & $\begin{array}{r}21.45 \\
0.46 \\
6.06 \\
10.97 \\
0.38 \\
1.29 \\
1.05 \\
1.24\end{array}$ & $\begin{array}{l}\ldots .153 \\
3.03 \\
1.83 \\
0.0633 \\
0.0717 \\
0.0875 \\
0.0344\end{array}$ & $\begin{array}{l}\cdots \\
4.45^{*} \\
8.81^{*} \\
5.32^{*} \\
1.84 \dagger \\
2.08 \dagger \\
2.54 \dagger \\
\ldots \ldots\end{array}$ & $\begin{array}{l}3.38 \\
5.25 \\
3.35 \\
2.36 \\
1.90 \\
2.03 \\
\ldots\end{array}$ \\
\hline
\end{tabular}

* Significant at the 1 per cent level.

† Significant at the 5 per cent level. 
variety and ripeness. Color of light appeared not to be uniformly important; this was altogether true when a large number of tasters was considered. There was some indication that white light helped in consisteney and uniformity of taste rating in some cases. Interactions tasters $\times$ variety, taster $\times$ ripeness, taster $\times$ light, variety $\times$ ripeness, and variety $\times$ light, were all significant at the 1 per cent level.

3. Judging color with seven panel members. The same seven-member panel as above completed six or more color score sheets. Important differences were found between degrees of ripeness, varieties of grapes, and judges. The interactions were not very important, as shown in the bottom analysis on page 11 .

In these exploratory analyses, all mean squares were tested against the experimental error or residual mean square (Kendall, 1955). Because of the interactions some of the primary effects should be tested against larger error terms, but as far as significance or nonsignificance is concerned there would be only minor changes. In any case, the statements made indicate the relative importance of the mean squares and heterogeneity due to the specified causes.

\section{Chemical and sensory data, 1960}

The 1960 season showed the same trends as did 1959, even though only three levels of maturity were used. Taste acceptability was correlated with maturity for all of the varieties; however, only the pigmented varieties Cardinal and Tokay showed a clear relationship between color acceptability and maturity. The analysis of variance treatment applied to the 1959 data was also applied to the $\mathbf{1 9 6 0}$ data and results obtained were the same.

Sample variability, and the shortness of the post-harvest period during which the grapes were suitable for sensory purposes, imposed severe restrictions on further improvement in the sensory data and reliability of conclusions drawn from these data. Individual discriminatory ability was difficult to assess because of such great variability among berries, especially when maturity samples were arranged $1^{\circ}$ Balling apart within a range of 2 to $3^{\circ}$ Balling on the basis of the average composition of each sample. Also, differences in sensorv acceptability among individual tasters were difficult to evaluate owing to this rariability, and because of the few tastings possible for a given sample before texture changes in the fruit induced by dehydration in storage made further tests impractical.

The limited post-harvest life of the samples also precluded a satisfactory comparison of the Balling/acid ratio with degree Balling alone as an index of sensory acceptabiilty. To make this a critical study, it appeared necessary to harvest samples from the same vineyard at the same degree Balling but on different dates. Since the acid content continues to decrease during ripening, it is possible to obtain samples at the same degree Balling but at different acid levels by harvesting them at 1 to 2 -week intervals. If the first sample can be held in cold storage so that the texture remains essentially unchanged (berries remain turgid) until the second sample is available, it is possible to make direct comparisons between samples with the same degree Balling but different ratios. Such a comparison would require that grapes be held with little or no detectable change in texture and flavor for a minimum of 2 weeks - a difficult problem when the critical timing of sampling, prevailing temperatures during sampling, distances of transport, and rigors of sample preparation are considered.

\section{Sample variability, 1961}

From the foregoing results it was apparent that sample variability had become a limiting factor to further study relating maturity to sensory acceptability. Differences in degree Balling among berries within a cluster are no 
particular problem when that cluster is used as the smallest unit in a test, as in the conventional method of measuring maturity. However, for sensory studies it becomes necessary to consider the berry as the smallest unit, because taste fatigue limits the taster's capacity to this magnitude of sample size if he is to discriminate effectively between maturity levels $1^{\circ}$ Balling apart.

The seriousness of the problem is illustrated by the amount of variability among berries within clusters. Even the more uniform clusters of Thompson Seedless and Perlette grapes had only 40 to 55 per cent of the berries within $0.5^{\circ}$ Balling, and 65 to 85 per cent within $1.0^{\circ}$ Balling of the average for the cluster.

The Cardinal variety showed more variability than the Perlette and Thompson Seedless because, in addition to the variability among berries of the same size, there was a wide range in berry size and the degree Balling had a strong inverse relationship to size. Variability in this variety from a specific gravity standpoint was further increased by the number of seeds per berry, which varied from 0 to 5 . The number itself would not be a factor were it not for the fact that the specific gravity of these seeds varied widely. This variation was demonstrated with
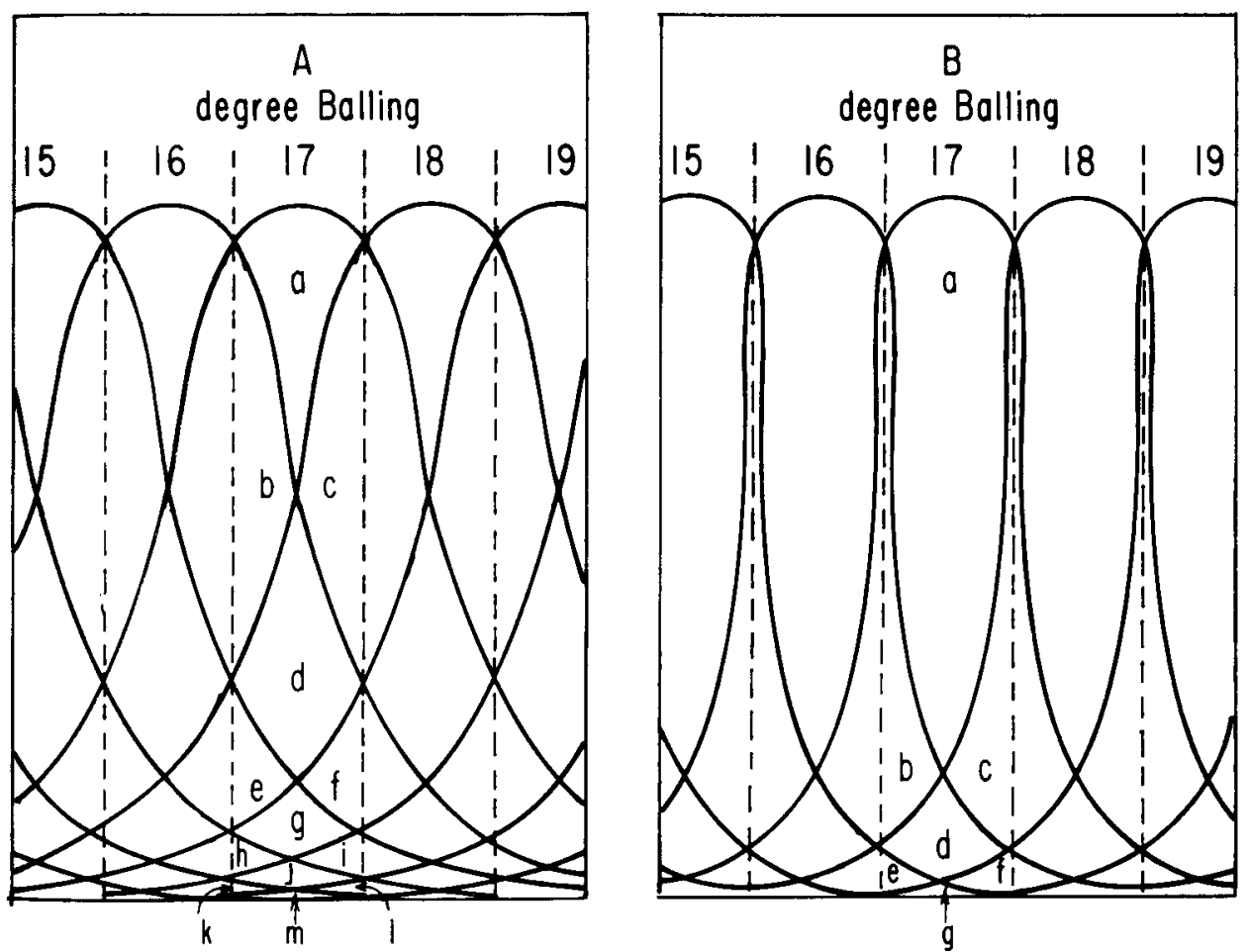

Figure 1. Variability in degree Balling of berries in grape samples arranged at $1^{\circ}$ Balling intervals. A. Samples segregated on the basis of single-berry determinations of 3 to $6 \%$ of the berries of each cluster. Within the $17^{\circ}$ Balling fraction the percentage of the berries at the various degree Ballings are: a. $17^{\circ} \mathrm{B}, 21.1 \%$; b. $16^{\circ} \mathrm{B}, 18.1 \%$; c. $18^{\circ} \mathrm{B}, 18.1 \%$; d. $16 \& 18^{\circ} \mathrm{B}$, $21.4 \%$; e. $15^{\circ} \mathrm{B}, 5.7 \%$; f. $19^{\circ} \mathrm{B}, 5.7 \%$; g. $15 \& 19^{\circ} \mathrm{B}, 4.2 \%$; h. $14^{\circ} \mathrm{B}, 1.8 \%$; i. $20^{\circ} \mathrm{B}$, $1.8 \%$; j. $14 \& 20^{\circ} \mathrm{B}, 1.5 \%$; k. $13^{\circ} \mathrm{B}, 0.2 \%$; l. $21^{\circ} \mathrm{B}, 0.2 \%$; and m. $13 \& 21^{\circ} \mathrm{B}, 0.2 \%$. B. Samples segregated on the basis of specific gravity, using sucrose solutions $1^{\circ}$ Balling apart. Within the $17^{\circ}$ Balling fraction the percentage of berries at the various degree Ballings are: a. $17^{\circ} \mathrm{B}, 57.6 \%$; b. $16^{\circ} \mathrm{B}, 15.4 \%$; c. $18^{\circ} \mathrm{B}, 15.4 \%$; d. $16 \& 18^{\circ} \mathrm{B}, 7.8 \%$; e. $15^{\circ} \mathrm{B}, 1.6 \%$; f. $19^{\circ} \mathrm{B}, 1.6 \%$; and g. $15 \& 19^{\circ} \mathrm{B}, 0.6 \%$. 
TABLE 6

PERCENTAGE OF BEIRIES IN 10-BERRY SAMPLES DEVIATING FROM AVERAGE TOTAL ACID CONTENT OF THE SAMPLE

\begin{tabular}{|c|c|c|c|c|c|c|}
\hline \multirow{2}{*}{ Variety } & \multirow{2}{*}{$\begin{array}{c}\text { Date } \\
\text { harvested }\end{array}$} & \multirow{2}{*}{$\begin{array}{l}\text { Balling } \\
\text { degrees* }\end{array}$} & \multirow{2}{*}{$\begin{array}{c}\text { Average } \\
\text { total acid } \\
\text { (gm tartaric } \\
\text { l00 } \mathrm{gm})\end{array}$} & \multicolumn{3}{|c|}{$\begin{array}{l}\text { Percentage of berries within } \\
\text { indicated deviation }\end{array}$} \\
\hline & & & & $\begin{array}{c} \pm 0.2 \\
(\mathrm{gm} / 100 \mathrm{gm})\end{array}$ & $\begin{array}{c} \pm 0.1 \\
(\mathrm{gm} / 100 \mathrm{gm})\end{array}$ & $\begin{array}{c} \pm 0.05 \\
(\mathrm{gm} / 100 \mathrm{gm})\end{array}$ \\
\hline Perlette.... & $5-23$ & 16 & 1.13 & 100 & 70 & 40 \\
\hline Perlette... & $5-31$ & 16 & 0.90 & 100 & 70 & 40 \\
\hline Perlette... & $5-23$ & 17 & 1.10 & 90 & 60 & 20 \\
\hline Perlette... & $5-31$ & 17 & 0.88 & 90 & 90 & 50 \\
\hline Perlette.... & $5-23$ & 18 & 1.09 & 100 & 80 & 50 \\
\hline Perlette.............. & $5-31$ & 18 & 0.87 & 100 & 90 & 70 \\
\hline Cardinal . ........... & $6-1$ & 16 & 0.80 & 90 & 80 & 40 \\
\hline Cardinal............. & $6-8$ & 16 & 0.74 & 100 & 100 & 60 \\
\hline Cardinal........ & $6-1$ & 17 & 0.79 & 100 & 70 & 30 \\
\hline Cardinal ......... & $6-8$ & 17 & 0.75 & 100 & 100 & 70 \\
\hline Cardinal.............. & $6-1$ & 18 & 0.81 & 100 & 90 & 70 \\
\hline Cardinal...$\ldots \ldots \ldots$. & $6-8$ & 18 & 0.79 & 100 & 100 & 80 \\
\hline Thompson Seedless..... & $6-8$ & 16 & 1.36 & 80 & 40 & 30 \\
\hline Thompson Seedless..... & $6-22$ & 16 & 1.25 & 70 & 60 & 20 \\
\hline Thompson Seedless.... & $6-8$ & 17 & 1.25 & 90 & 50 & 20 \\
\hline Thompson Seedless.... & $6-22$ & 17 & 0.97 & 30 & 10 & 0 \\
\hline Thompson Seedless..... & $6-8$ & 18 & 1.07 & 100 & 80 & 40 \\
\hline Thompson Seedless..... & $6-22$ & 18 & 0.79 & 100 & 80 & 60 \\
\hline
\end{tabular}

* Range in degree Balling of each sample is similar to that shown for a $17^{\circ}$ Balling sample in figure $1, B$.

a sample of seeds separated from the pulp of $17^{\circ}$ Balling grapes and immersed in water and suerose solutions of different concentrations. About half of the seeds floated in pure water (specific gravity less than 1), 5 per cent floated in a $5^{\circ}$ Balling solution, 6 per cent at $10^{\circ}$ Balling, 7 per cent at $15^{\circ}$ Balling, 10 per cent at $20^{\circ}$ Balling, 10 per cent at $25^{\circ}$ Balling, 9 per cent at $30^{\circ}$ Balling and 4 per cent at $35^{\circ}$ Balling. As a result of these variability factors only 30 to 40 per cent of the berries of a Cardinal cluster were within $0.5^{\circ}$, and 55 to 65 per cent within $1.0^{\circ}$ Balling of the average for the cluster.

When samples of detached berries were segregated on a specific gravity basis in a series of sucrose solutions $1.0^{\circ}$ Balling apart, variability was drastically reduced. For Thompson Seedless and Perlette grapes, 65 to 70 per cent of the berries were now within $0.5^{\circ}$ and 85 to 95 per cent within $1.0^{\circ}$ Balling of the average of the cluster. For Cardinal, 55 to 65 per cent were within $0.5^{\circ}$, and 85 to 95 per cent within $1.0^{\circ}$ Balling of the average. Figure 1 shows the effect of this specific gravity separation method on the range of variability of berries within samples with average soluble solids levels $1.0^{\circ}$ Balling apart. The proportion of berries within $0.5^{\circ}$ Balling of the average was increased from 21.1 per cent for the $17^{\circ}$ Balling sample selected on a cluster basis by refractometer (figure 1, A) to 57.6 per cent for the sample segregated in sucrose solutions of 16.5 and $17.5^{\circ}$ Balling (figure $1, \mathrm{~B})$.

Variability in the total acid content among berries of a grape cluster was often found to be of greater relative magnitude than variability in total soluble solids. Within 10 berry samples, all at the same degree Balling, the total acid content of some berries was double that of others. As a result the Balling/ acid ratio of the low-acid berry was twice that of the high-acid berry.

Table 6 shows the percentage of berries deviating from the average total acid content of the sample and the magnitude of this deviation. Deviations are generally greatest and involve the largest proportion of the berries at the lower 
maturity levels of each variety and are especially high for Thompson Seedless for high acid conditions. Although the Cardinal shows the least amount of variability, the actual proportion is just as high as that for the seedless varieties. For example, a deviation of \pm 0.1 $\mathrm{gm} / 100 \mathrm{gm}$ from an average total acid content of $0.8 \mathrm{gm} / 100 \mathrm{gm}$ would cause considerably more variability in the Balling/acid ratio than a like deviation from an average total acid of $1.36 \mathrm{gm} /$ $100 \mathrm{gm}$.

This source of rariability is especially

TABLE 7

VARIETY, SOURCE, DATE OF HARVEST, AND CHEMICAL COMPOSITION OF TABLE GRAPES USED FOR TASTE AND COLOR ACCEPTABILITY TESTS, 1961

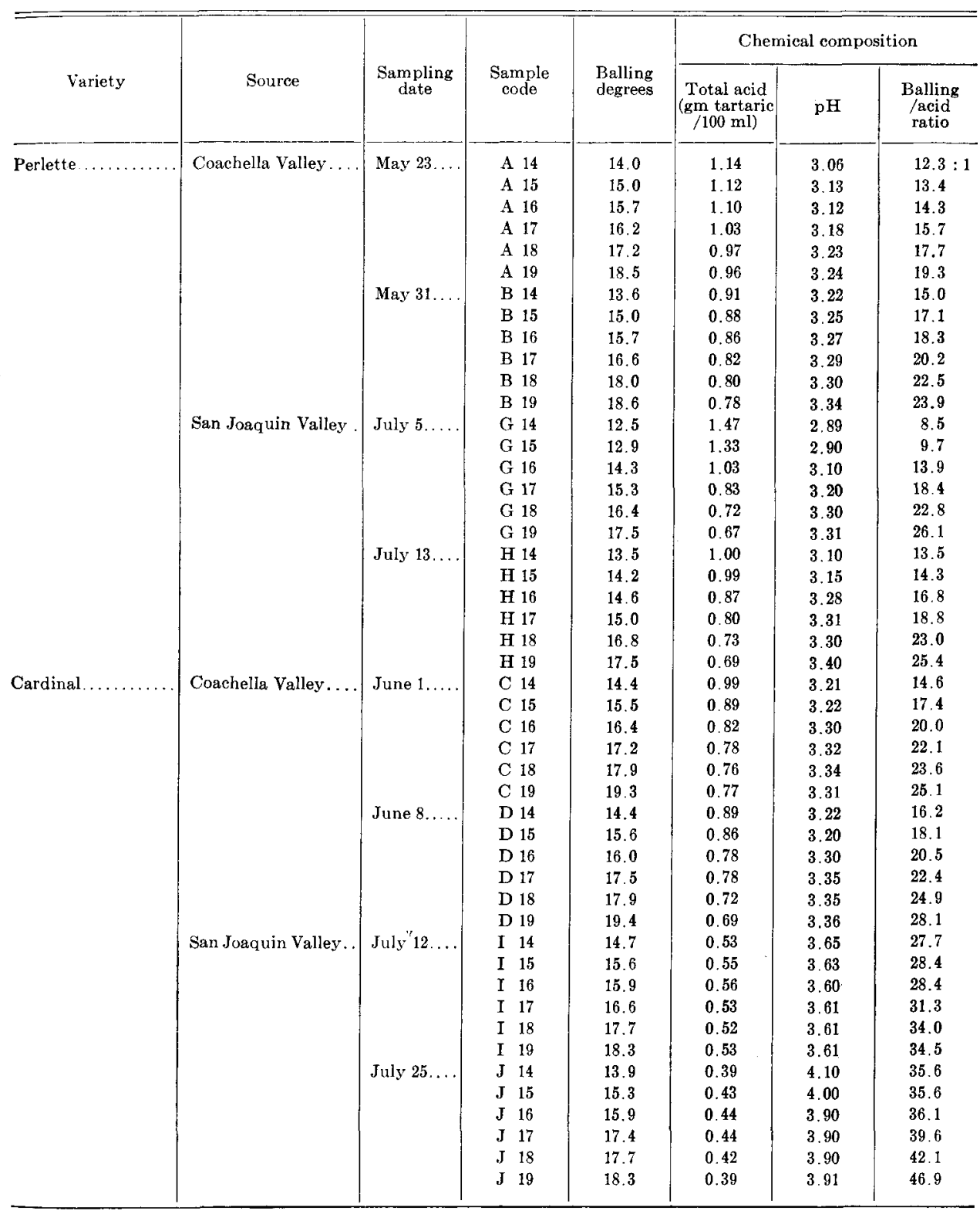


TABLE 7-Continued

\begin{tabular}{|c|c|c|c|c|c|c|c|}
\hline \multirow[b]{2}{*}{ Variety } & \multirow[b]{2}{*}{ Source } & \multirow[b]{2}{*}{$\begin{array}{l}\text { Sampling } \\
\text { date }\end{array}$} & \multirow[b]{2}{*}{$\begin{array}{l}\text { Sample } \\
\text { code }\end{array}$} & \multirow[b]{2}{*}{$\begin{array}{l}\text { Balling } \\
\text { degrees }\end{array}$} & \multicolumn{3}{|c|}{ Chemical composition } \\
\hline & & & & & $\begin{array}{c}\text { Total acid } \\
\text { (gm tartaric } \\
/ 100 \mathrm{ml})\end{array}$ & $\mathrm{pH}$ & $\begin{array}{c}\text { Balling } \\
\text { /acid } \\
\text { ratio }\end{array}$ \\
\hline Thompson Seedless. & $\begin{array}{l}\text { Coachella Valley.... } \\
\text { San Joaquin Valley.. }\end{array}$ & $\begin{array}{l}\text { June } 8 \ldots . \\
\text { June } 22 \ldots . \\
\text { July } 25 \ldots . \\
\text { August } 7 . .\end{array}$ & $\begin{array}{lll}\text { E } & 14 \\
\text { E } & 15 \\
\text { E } & 16 \\
\text { E } & 17 \\
\text { E } & 18 \\
\text { E } & 19 \\
\text { F } & 14 \\
\text { F } & 15 \\
\text { F } & 16 \\
\text { F } & 17 \\
\text { F } & 18 \\
\text { F } & 19 \\
\text { K } & 14 \\
\text { K } & 15 \\
\text { K } & 16 \\
\text { K } & 17 \\
\text { K } & 18 \\
\text { K } & 19 \\
\text { L } & 14 \\
\text { L } & 15 \\
\text { L } & 16 \\
\text { L } & 17 \\
\text { L } & 18 \\
\text { L } & 19\end{array}$ & $\begin{array}{l}13.8 \\
15.7 \\
17.0 \\
17.5 \\
18.7 \\
19.5 \\
13.8 \\
15.5 \\
16.6 \\
17.7 \\
18.5 \\
19.4 \\
14.7 \\
15.5 \\
16.8 \\
17.0 \\
18.5 \\
19.2 \\
14.3 \\
15.4 \\
17.1 \\
17.5 \\
18.5 \\
19.4\end{array}$ & $\begin{array}{l}1.92 \\
1.54 \\
1.41 \\
1.30 \\
1.29 \\
1.21 \\
1.02 \\
0.99 \\
0.94 \\
0.91 \\
0.85 \\
0.78 \\
0.95 \\
0.88 \\
0.80 \\
0.79 \\
0.72 \\
0.68 \\
0.66 \\
0.66 \\
0.61 \\
0.56 \\
0.56 \\
0.55\end{array}$ & $\begin{array}{l}2.85 \\
2.91 \\
3.00 \\
3.05 \\
3.04 \\
3.02 \\
\ldots . \\
3.09 \\
3.12 \\
3.19 \\
3.20 \\
3.11 \\
3.22 \\
3.31 \\
3.40 \\
3.41 \\
3.42 \\
3.51 \\
3.50 \\
3.50 \\
3.55 \\
3.61 \\
3.61 \\
3.69\end{array}$ & $\begin{array}{r}7.2 \\
10.2 \\
12.1 \\
13.5 \\
14.5 \\
16.1 \\
13.5 \\
15.7 \\
17.7 \\
19.5 \\
21.8 \\
24.9 \\
15.5 \\
17.6 \\
21.0 \\
21.5 \\
25.7 \\
28.2 \\
21.7 \\
23.3 \\
28.0 \\
31.3 \\
33.0 \\
35.3\end{array}$ \\
\hline
\end{tabular}

serious in sensory studies since it cannot be materially reduced by segregating the berries on a specific gravity basis. The best method of coping with this problem appears to be by using a large number of the same tasters (minimum of twenty for each tasting) and repeat the tastings at least five times for each set of samples.

\section{Composition of grapes for sensory tests, 1961}

Table 7 shows the varieties, source, date of sampling and composition of the grapes used for taste and color acceptability tests. The six levels of degree Balling within each sampling agree quite closely to the planned levels of 14 to $19^{\circ}$ Balling, as is indicated by comparing the Sample Code value with the actual corresponding Balling levels. Only the levels for Perlettes sampled on July 5 and 13 deviate more than $1.1^{\circ}$ Balling from the expected levels. For some reason (probably experimental error in preparing the fractionating solutions) these twelve Perlette values are lower than expected. Later in the season, agreement was closer as techniques of sample preparation improved. No levels overlapped or were the same within each series of six samples harvested at the same time.

Total acid content of the samples showed an inverse relationship to the degree Balling, at least at the moderate to high acid levels of the Perlette and Thompson Seedless grapes. This relationship was quite general even for Cardinals until acidity was reduced to the low levels shown for the I and J samples in table 7 .

The total acid content of each lot sampled early was consistently higher than that in the sample with the same Balling sampled later. The only reversals to this trend were samples G 18 and 19, which were lower in acid than H 18 and 19, respectively. The amount of decrease in acid between samplings varied widely among the varieties and between areas, and was due largely to the length of time between sampling dates. Decrease for Perlette from both valleys, 
when sampling dates were only 8 days apart, was considerably less than the decrease for Thompson Seedless from the Coachella Valley when the dates were 13 days apart. Although varietal differences could be a factor in this comparison, the same relationship was apparent for Cardinal when the average decrease in acid of the Coachella fruit in 7 days was less than half the decrease in acid of the San Joaquin Valley fruit in 13 days.

The length of the period between samplings probably was not the only factor controlling the amount of decrease in acidity. Winkler has shown that the mean temperature during ripening has a significant effect on the rate of decrease of acid (Winkler, 1948). The mean temperature for the San Joaquin Valley Cardinals between sampling dates was $6^{\circ} \mathrm{F}$ higher than that for the Coachella Valley fruit (table 8). This higher temperature was undoubtedly a contributing factor to the rate of decrease in acidity and thus to the amount of difference between the two samplings.

The acid content of fruit at the first sampling varied widely with variety and area. This acid level was usually inversely related to the average daily temperature during the 30-day period prior to sampling, and thus to the heat summation values (table 8 ). Mean ripening temperatures were lower in the Coachella Valley than in the San Joaquin Valley, which is unusual. The means were especially different for the Cardinal and Thompson Seedless varieties. For Cardinal, a difference of $8.3^{\circ} \mathrm{F}$ made a difference of 249 degreedays during the 30 days prior to sampling. As a result, the average acid content of the San Joaquin Valley Cardinals was about two-thirds that of the Coachella Valley fruit. For the Thompson Seedless, the means differed by $6.1^{\circ} \mathrm{F}$ and the degree-days value by 183. This difference caused the average acid content of the San Joaquin Valley fruit to be slightly over one-half that of the Coachella Valley fruit. The Perlette, however, did not show this difference. In spite of a difference in the mean of $2.7^{\circ} \mathrm{F}$ and 111 degree-days the acid contents were essentially the same for fruit from the two valleys. Although the difference in the mean temperatures was much smaller than for Cardinal or Thompson Seedless, and therefore

TABLE 8

AVERAGE DAILY TEMPERATURE AND HEAT SUMMATION BEFORE HARVEST, AND AVERAGE TOTAL ACID FOR GRAPE SAMPLES USED IN CHEMICAL AND SENSORY TESTS, 1961

\begin{tabular}{|c|c|c|c|c|c|c|}
\hline \multirow[b]{2}{*}{ Variety and location } & \multicolumn{2}{|c|}{ Average daily temperature } & \multicolumn{2}{|c|}{ Heat summation } & \multicolumn{2}{|c|}{ Average total acid } \\
\hline & $\begin{array}{l}\text { 30-day period } \\
\text { prior to first } \\
\text { sampling }\end{array}$ & $\begin{array}{c}\text { Period be- } \\
\text { tween 1st and } \\
\text { 2nd sampling }\end{array}$ & $\begin{array}{c}\text { 30-day period } \\
\text { prior to first } \\
\text { sampling }\end{array}$ & $\begin{array}{c}\text { Period be- } \\
\text { tween 1st and } \\
\text { 2nd sampling }\end{array}$ & 1st sample* & 2nd sample $\dagger$ \\
\hline & \multicolumn{2}{|c|}{ Degrees $F$} & \multicolumn{2}{|c|}{ Degree-days } & \multicolumn{2}{|c|}{$g m s / 100 m l$} \\
\hline \multicolumn{7}{|l|}{ Perlette: } \\
\hline Coachella Valley. & 76.6 & 79.4 & 798 & 235 & 1.05 & 0.84 \\
\hline San Joaquin Valley... & 80.3 & 81.3 & 909 & 250 & 1.07 & 0.85 \\
\hline \multicolumn{7}{|l|}{ Cardinal: } \\
\hline Coachella Valley. & 77.5 & 82.1 & 825 & 225 & 0.83 & 0.79 \\
\hline San Joaquin Valley ...... & 85.8 & 88.1 & 1074 & 495 & 0.54 & 0.42 \\
\hline \multicolumn{7}{|l|}{ Thompson Seedless: } \\
\hline Coachella Valley... & 79.3 & 89.7 & 879 & 556 & 1.45 & 0.92 \\
\hline San Joaquin Valley...... & 85.4 & 84.8 & 1062 & 322 & 0.80 & 0.60 \\
\hline
\end{tabular}

* 30-day period before 1st sampling.

$\dagger$ Period between 1st and 2nd sampling. 
smaller differences in total acid would be expected, the fact that there was no difference (a small reversal, in fact) is difficult to explain other than on the basis of experimental error or unrepresentative temperature records. The Coachella Valley vineyard was only 5 miles from the Weather Bureau station where the temperatures were recorded, while the San Joaquin Valley vineyard was about 30 miles distant; the latter station is located in an urban environment which tends to have higher mean temperatures than surrounding agricultural areas. A mean temperature only $2.7^{\circ} \mathrm{F}$ above that in the vineyard would place the degree-day value of the vineyard at the same level as that for the Coachella Valley vineyard, and this would explain the lack of difference in total acid content of the fruit samples.

There was a varietal effect on the level of total acid in the samples. Cardinals from the Coachella Valley which had been exposed to 825 degree days of heat had a total acid content of only 0.83 grams tartaric per 100 milliliters of juice, Perlette with only 27 degree days less had 1.05 grams, while Thompson Seedless with 879 degree days still contained 1.45 grams of acid. The same relationship was apparent for the San Joaquin Valley fruit, demonstrating that at the same degree Balling and heat summation level Cardinal has the lowest total acid content and Thompson Seedless the highest, with Perlette occupying an intermediate position.

The $\mathrm{pH}$ of the samples showed an inverse relationship to the acid content although the trends were less consistent (table 7). Values ranged from 2.85, for sample E 14, to as high as 4.10 for J 14 .

The Balling/acid ratio of the samples showed a consistent relationship to the degree Balling, as would be expected since the acid content showed a consistent inverse relationship (table 7 ). The range in ratio for each sample series was great enough so that the two sampling ranges overlapped with the exception of the $I$ and $J$ series. Here, the acid content of the $J$ samples was so low that the ratio of $J 14$ was higher than that of I 19. On the other hand the $\mathrm{C}$ and $\mathrm{D}$ series completely overlapped, thus pro-

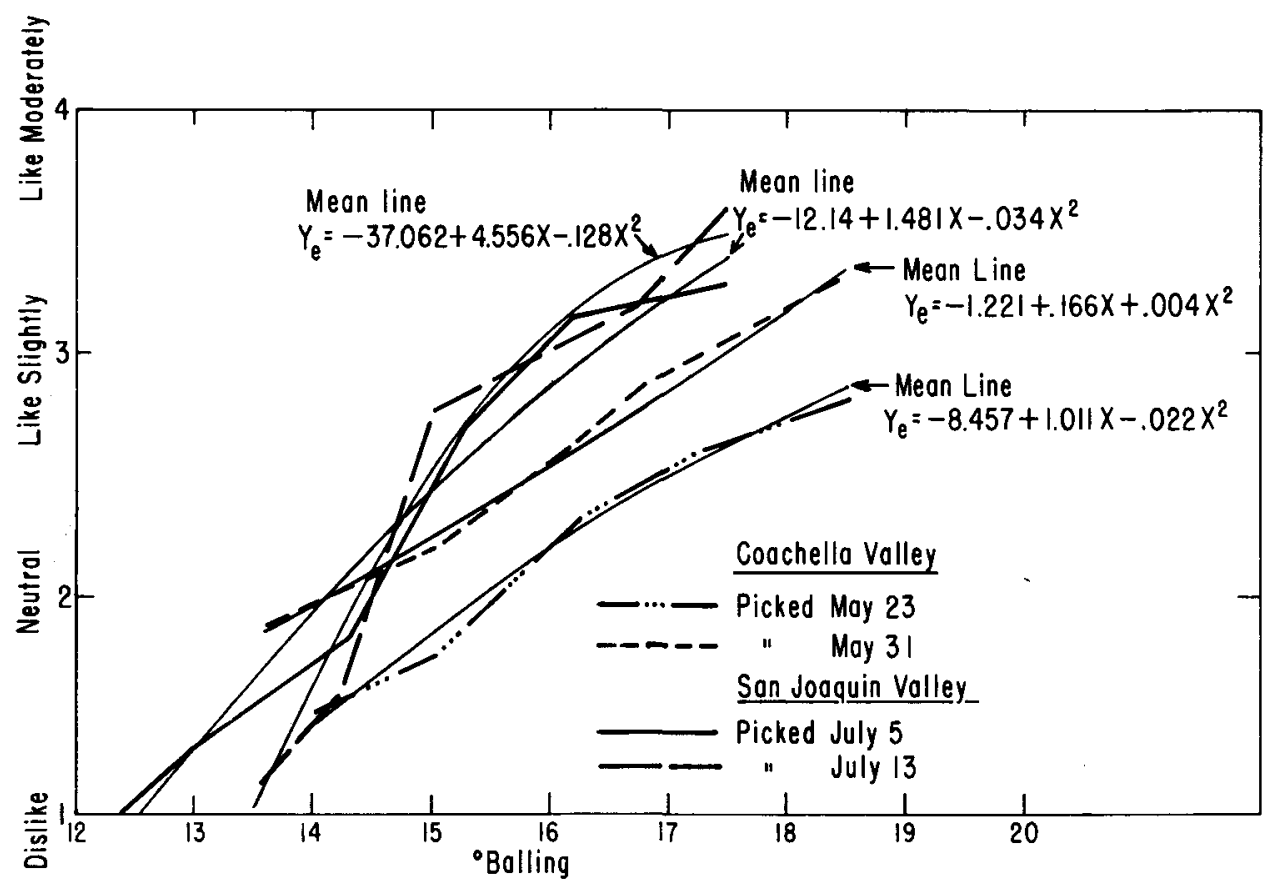

Figure 2. Relationship between taste acceptability and degree Balling of Perlette grapes, 1961. 


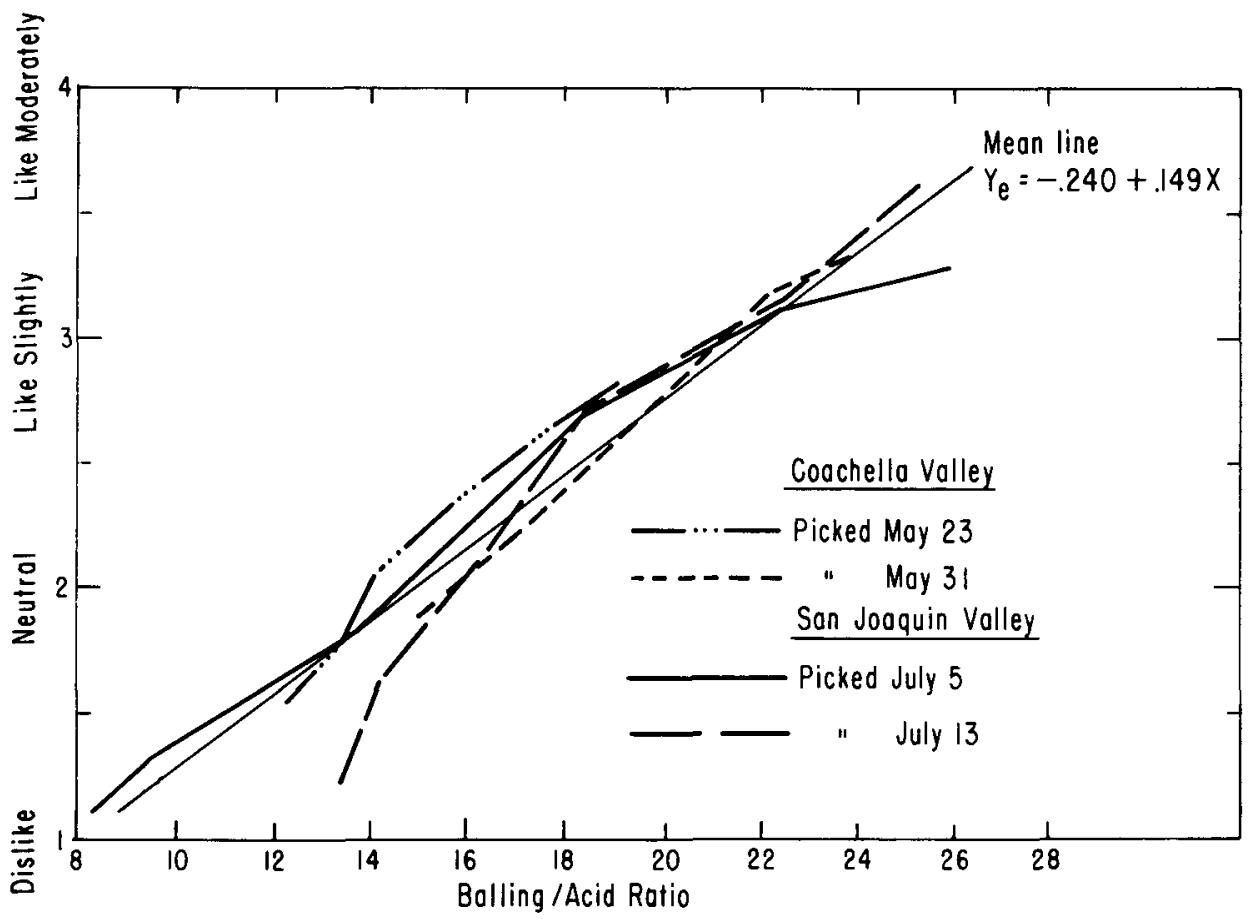

Figure 3. Relationship between taste acceptability and Balling/ acid ratio of Perlette grapes, 1961.

viding an excellent opportunity to apply sensory tests over a wide maturity range to samples of comparable degree Ballings but of different Balling/acid ratios.

\section{Perlette sensory tests}

Figure 2 shows the relationship between taste preference and the degree Balling of Perlette grapes; there is an increase in acceptability with increase in degree Balling for all samplings. The second sampling from the Coachella Valley had higher acceptability than the first, and this can be explained on the basis of the difference in the acid level of the two samplings (table 7 ). There appears to be little difference in acceptability between the first and second samplings from the San Joaquin Valley, except at the lower Balling levels. This would be expected on the basis of the acid content of the fruit (table 7 ). At the lower degree Balling the acid values between the first and second samplings are widely separated. However, at inter- mediate and upper levels the differences almost disappear.

Figure 3 gives the same data as figure 2, but on the basis of the Balling/acid ratio. It is apparent that a more meaningful mean line can be drawn showing the relationship between acceptability and Balling/acid ratio than can be established between acceptability and degree Balling alone.

Table 9 shows the percentage of taste decisions with five acceptability levels on Perlette grapes of twelve Balling/ acid ratios. Data in this table further support the conclusion concerning the value of the Balling/acid ratio as an index with which to predict taste acceptability. For example, the "dislike" reaction shows a consistent trend downward with increase in ratio. Wide differences in reaction are evident if the same degree Balling levels are compared that were picked on different dates - that is, samples picked at different acid levels. For example, the Coachella Valley Perlette sample picked on May 23 at 


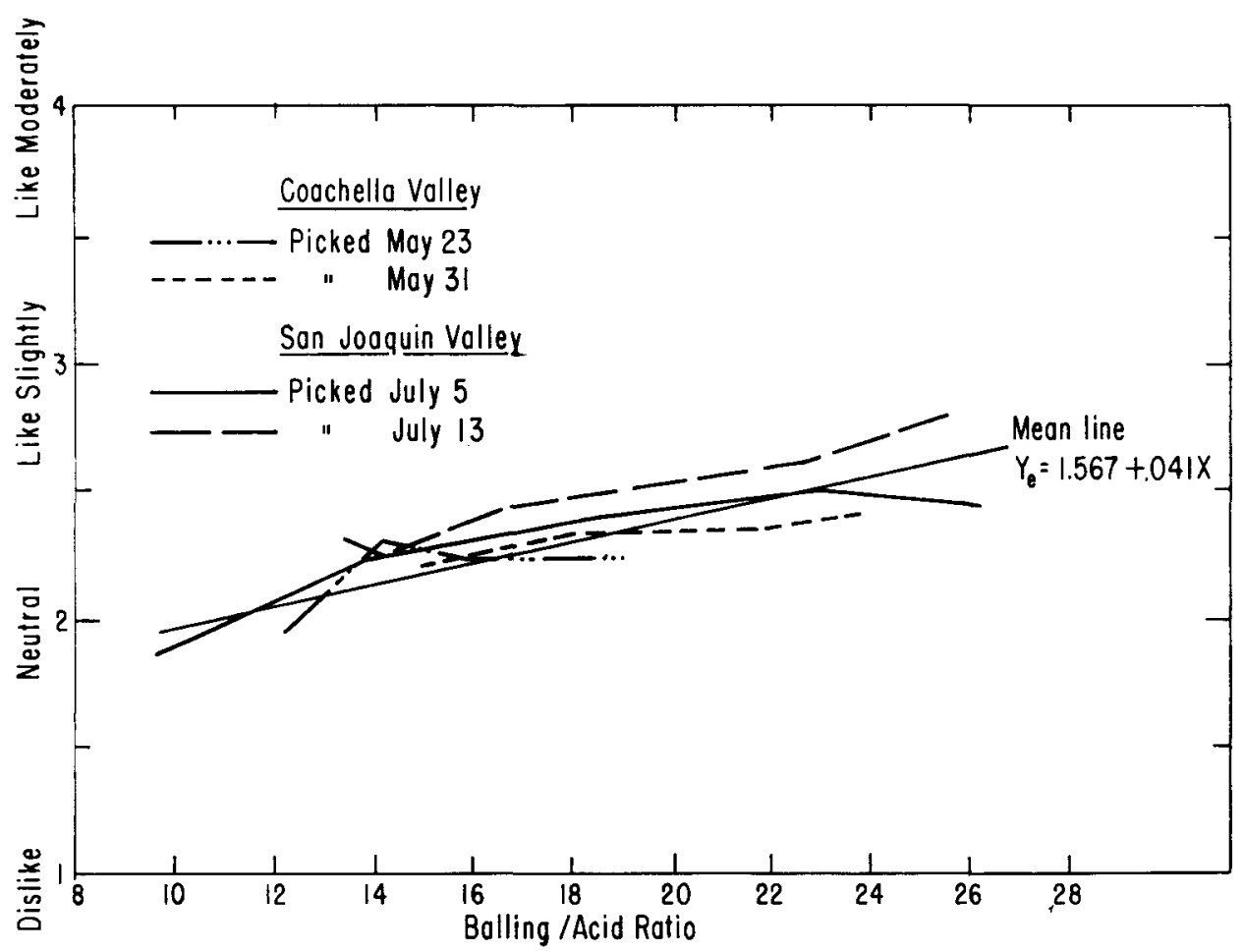

Figure 4. Relationship between color acceptability and Balling/acid ratio of Perlette grapes, 1961.

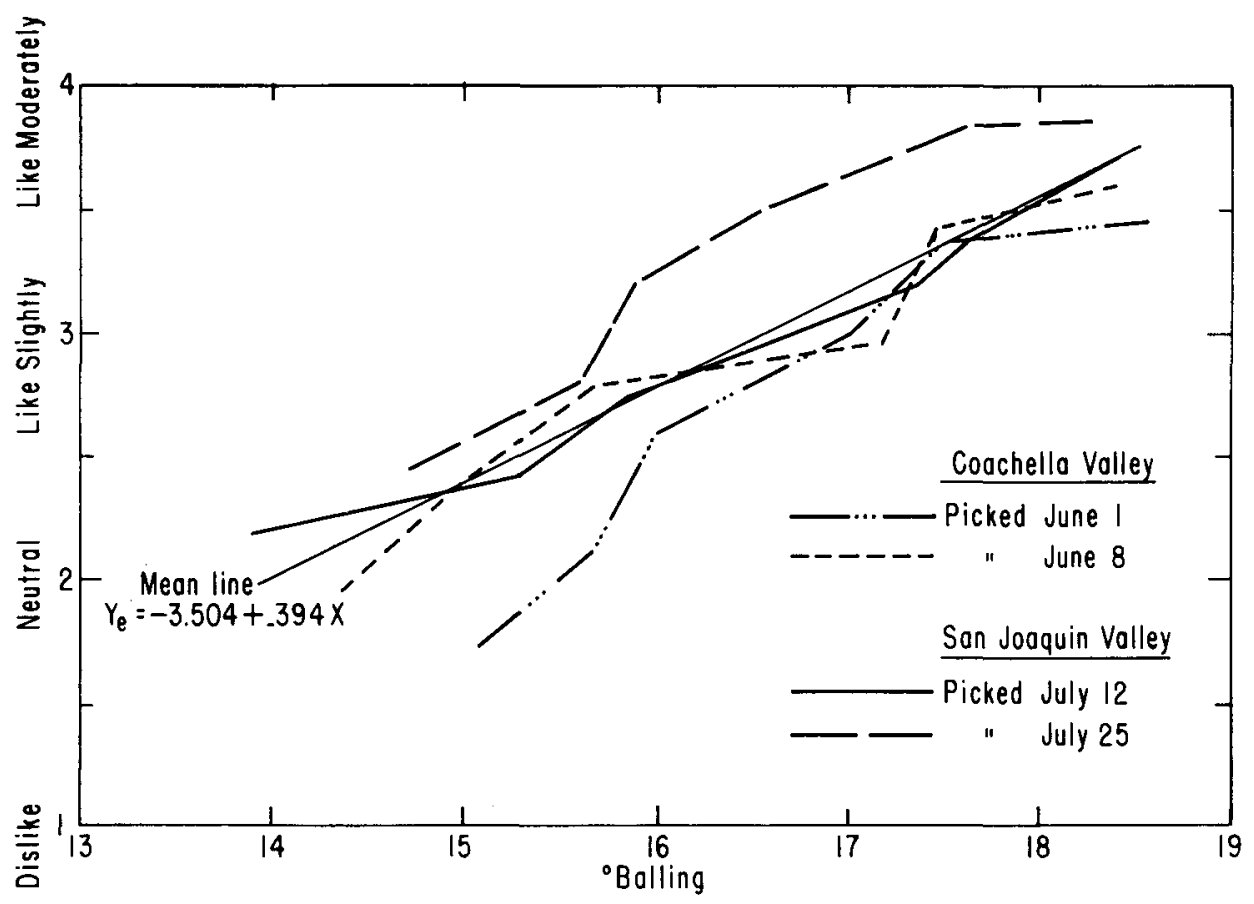

Figure 5. Relationship between taste acceptability and degree Balling of Cardinal grapes, 1961. 
TABLE 9

PERCENTAGE OF TASTE DECISIONS ON GRAPES OF 12 BALLING/ACID RATIOS USING A 5-POINT HEDONIC SCALE

\begin{tabular}{|c|c|c|c|c|c|c|c|c|}
\hline \multirow[b]{2}{*}{ Variety and location } & \multirow[b]{2}{*}{$\begin{array}{l}\text { Picking } \\
\text { date }\end{array}$} & \multirow[b]{2}{*}{$\begin{array}{l}\text { Balling/ } \\
\text { acid } \\
\text { ratio }\end{array}$} & \multirow[b]{2}{*}{$\begin{array}{l}\text { Balling } \\
\text { degree }\end{array}$} & \multicolumn{5}{|c|}{ Taste decisions } \\
\hline & & & & Dislike & Neutral & $\begin{array}{c}\text { Like } \\
\text { slightly }\end{array}$ & $\begin{array}{l}\text { Like } \\
\text { moder- } \\
\text { ately }\end{array}$ & $\begin{array}{l}\text { Like ex- } \\
\text { tremely }\end{array}$ \\
\hline & & & & \multicolumn{5}{|c|}{ Jer cent } \\
\hline \multirow{12}{*}{$\begin{array}{l}\text { Perlette: } \\
\text { Coachella Valley. }\end{array}$} & $5 / 23$ & 12.3 & 14.0 & 68.8 & 16.8 & 9.6 & 4.0 & 0.8 \\
\hline & $5 / 23$ & 13.4 & 15.0 & 54.1 & 23.6 & 16.2 & 4.7 & $\begin{array}{l}0.0 \\
1.4\end{array}$ \\
\hline & $5 / 23$ & 14.3 & 15,7 & 36.7 & 30.6 & 24.5 & 6.1 & 2,1 \\
\hline & $5 / 31$ & 15.0 & 13.6 & 45.6 & 32.0 & 13.6 & 7.2 & 1.7 \\
\hline & $5 / 23$ & 15.7 & 16.2 & 31.3 & 21.8 & 34.0 & 10.2 & 2.7 \\
\hline & $5 / 31$ & 17.1 & 15.0 & 34.0 & 30.6 & 21.1 & 10.2 & 4.1 \\
\hline & $5 / 23$ & 17.7 & 17.2 & 19.6 & 22.3 & 39.2 & 14.2 & 4.7 \\
\hline & $5 / 31$ & 18.3 & 15.7 & 24.5 & 26.5 & 33.3 & 12.9 & 2.8 \\
\hline & $5 / 23$ & 19.3 & 18.5 & 13.7 & 28.1 & 27.4 & 21.9 & 8.9 \\
\hline & $5 / 31$ & 20.2 & 16.6 & 16.4 & 26.0 & 26.0 & 24.0 & 7.6 \\
\hline & $5 / 31$ & 22.5 & 18.0 & 6.8 & 22.3 & 27.7 & 29.7 & 13.5 \\
\hline & $5 / 31$ & 23.9 & 18.6 & 5.3 & 14.9 & 33.8 & 31.8 & 14.2 \\
\hline \multirow{12}{*}{ San Joaquin Valley ............... } & $7 / 5$ & 8.5 & 12.5 & 96.0 & 0.0 & 0.0 & 4.0 & 0.0 \\
\hline & $7 / 5$ & 9.7 & 12.9 & 76.2 & 17.5 & 3.2 & 2.8 & 0.3 \\
\hline & $7 / 13$ & 13.5 & 13.5 & 84.0 & 12.0 & 4.0 & 0.0 & 0.0 \\
\hline & $7 / 5$ & 13.9 & 14.3 & 48.8 & 27.8 & 16.3 & 6.7 & 0.4 \\
\hline & $7 / 13$ & 14.3 & 14.2 & 53.4 & 35.5 & 9.6 & 1.5 & 0.0 \\
\hline & $7 / 13$ & 16.8 & 14.6 & 29.2 & 34.8 & 24.4 & 9.6 & 2.0 \\
\hline & $7 / 5$ & 18.4 & 15.3 & 15.9 & 28.6 & 30.6 & 19.8 & 5.1 \\
\hline & $7 / 13$ & 18.8 & 15.0 & 10.3 & 30.6 & 35.7 & 18.7 & 4.7 \\
\hline & $7 / 5$ & 22.8 & 16.4 & 4.7 & 26.3 & 29.1 & 29.5 & 10.4 \\
\hline & $7 / 13$ & 23.0 & 16.8 & 3.2 & 21.0 & 37.7 & 29.4 & 8.7 \\
\hline & $7 / 13$ & 25.4 & 17.5 & 1.6 & 10.8 & 29.9 & 41.0 & 16.7 \\
\hline & $7 / 5$ & 26.1 & 17.5 & 5.0 & 17.8 & 28.9 & 36.8 & 11.5 \\
\hline \multirow{13}{*}{$\begin{array}{l}\text { Cardinal: } \\
\text { Coachella Valley } \ldots \ldots \ldots \ldots \ldots\end{array}$} & & & & & & & & \\
\hline & $6 / 1$ & 14.6 & 14.4 & 52.9 & 24.7 & 12.6 & 6.6 & 3.2 \\
\hline & $6 / 8$ & 16.2 & 14.4 & 43.0 & 30.7 & 15.1 & 9.5 & 1.7 \\
\hline & $6 / 1$ & 17.4 & 15.5 & 35.9 & 27.6 & 24.9 & 8.8 & 2.8 \\
\hline & $6 / 8$ & 18.1 & 15.6 & 21.7 & 36.7 & 20.0 & 16.7 & 4.9 \\
\hline & $6 / 1$ & 20.0 & 16.4 & 21,5 & 29.3 & 22.1 & 23.8 & 3.3 \\
\hline & $6 / 8$ & 20.5 & 16.0 & 8.9 & 34.4 & 27.8 & 23.9 & 5.0 \\
\hline & $6 / 1$ & 22.1 & 17.2 & 8.4 & 27.2 & 29.4 & 25.0 & 10.0 \\
\hline & $6 / 8$ & 22.4 & 17.5 & 10.5 & 22.7 & 33.1 & 26.0 & 7.7 \\
\hline & $6 / 1$ & 23.6 & 17.9 & 6.6 & 16.6 & 26.0 & 35.9 & 14.9 \\
\hline & $6 / 8$ & 24.9 & 17.9 & 2.8 & 18.0 & 28.4 & 35.0 & 15.8 \\
\hline & $6 / 1$ & 25.1 & 19.3 & 4.5 & 13.3 & 28.9 & 38.3 & 15.0 \\
\hline & $6 / 8$ & 28.1 & 19.4 & 1.7 & 14.1 & 22.6 & 45.2 & 16.4 \\
\hline \multirow[t]{12}{*}{ San Joaquin Valley .............. } & $7 / 12$ & 27.7 & 14.7 & 25.7 & 26.7 & 25.7 & 18.9 & 3.0 \\
\hline & $7 / 12$ & 28.4 & 15.6 & 13.2 & 27.8 & 29.3 & 23.9 & 5.8 \\
\hline & $7 / 12$ & 28.4 & 15.9 & 4.4 & 18.7 & 39.4 & 27.6 & 9.9 \\
\hline & $7 / 12$ & 31.3 & 16.6 & 2.0 & 15.2 & 29.9 & 32.8 & 20.1 \\
\hline & $7 / 12$ & 34.0 & 17.7 & 1.5 & 6.8 & 24.4 & 39.0 & 28.3 \\
\hline & $7 / 12$ & 34.5 & 18.3 & 0.5 & 6.3 & 26.8 & 36.6 & 29.8 \\
\hline & $7 / 25$ & 35.6 & 13.9 & 21.2 & 39.4 & 20.2 & 15.8 & 3.4 \\
\hline & $7 / 25$ & 35.6 & 15.3 & 26.5 & 43.1 & 17.6 & 11.3 & 1.5 \\
\hline & $7 / 25$ & 36.1 & 15.9 & 10.7 & 34.0 & 27.7 & 22.3 & 5.3 \\
\hline & $7 / 25$ & 39.6 & 17.4 & 6.9 & 18.6 & 31.4 & 30.4 & 12.7 \\
\hline & $7 / 25$ & 42.1 & 17.7 & 4.9 & 16.1 & 27.8 & 34.6 & 16.6 \\
\hline & $7 / 25$ & 46.9 & 18.3 & 5.0 & 11.8 & 21.2 & 37.9 & 24.1 \\
\hline
\end{tabular}


TABLE 9-Continued

\begin{tabular}{|c|c|c|c|c|c|c|c|c|}
\hline \multirow[b]{2}{*}{ Variety and location } & \multirow[b]{2}{*}{$\begin{array}{l}\text { Picking } \\
\text { date }\end{array}$} & \multirow{2}{*}{$\begin{array}{l}\text { Balling/ } \\
\text { acid } \\
\text { ratio }\end{array}$} & \multirow[b]{2}{*}{$\begin{array}{l}\text { Balling } \\
\text { degree }\end{array}$} & \multicolumn{5}{|c|}{ Taste decisions } \\
\hline & & & & Dislike & Neutral & $\begin{array}{c}\text { Like } \\
\text { slightly }\end{array}$ & $\begin{array}{l}\text { Like } \\
\text { moder- } \\
\text { ately }\end{array}$ & $\begin{array}{l}\text { Like ex- } \\
\text { tremely }\end{array}$ \\
\hline & & & & & & Per cent & & \\
\hline \multirow[t]{12}{*}{$\begin{array}{l}\text { Thompson Seedless: } \\
\text { Coachella Valley.. }\end{array}$} & $6 / 8$ & 7. 2 & 13.8 & 80.0 & 10.3 & 5.9 & 1.1 & 2.7 \\
\hline & $6 / 8$ & 10.2 & 15.7 & 72.6 & 16.1 & 8.1 & 2.2 & 1.0 \\
\hline & $6 / 8$ & 12.1 & 17.0 & 58.1 & 23.1 & 13.4 & 3.8 & 1.6 \\
\hline & $6 / 8$ & 13.5 & 17.5 & 41.7 & 31.6 & 19.3 & 5.9 & 1.5 \\
\hline & $6 / 25$ & 13.5 & 13.8 & 41.9 & 34.4 & 15.6 & 6.5 & 1.6 \\
\hline & $6 / 8$ & 14.5 & 18.7 & 24.3 & 34.1 & 24.3 & 13.0 & 4.3 \\
\hline & $6 / 25$ & 15.7 & 14.4 & 32.6 & 30.4 & 25.0 & 10.9 & 1.1 \\
\hline & $6 / 8$ & 16.1 & 19.5 & 18.8 & 24.2 & 30.1 & 20.4 & 6.5 \\
\hline & $6 / 25$ & 17.7 & 16.6 & 14.0 & 32.3 & 28.0 & 20.4 & 5.3 \\
\hline & $6 / 25$ & 19.5 & 17.7 & 5.3 & 29.6 & 35.5 & 21.0 & 8.6 \\
\hline & $6 / 25$ & 21.8 & 18.5 & 4.8 & 13.9 & 29.4 & 38.5 & 13.4 \\
\hline & $6 / 25$ & 24.9 & 19.4 & 2.6 & 12.4 & 34.4 & 33.9 & 16.7 \\
\hline \multirow[t]{12}{*}{ San Joaquin Valley ....... } & $7 / 25$ & 15.5 & 14.7 & 58.9 & 20.5 & 15.1 & 3.9 & 1.6 \\
\hline & $7 / 25$ & 17.6 & 15.5 & 48.5 & 22.7 & 21.2 & 6.2 & 1.4 \\
\hline & $7 / 25$ & 21.0 & 16.8 & 29.5 & 29.1 & 25.6 & 13.2 & 2.6 \\
\hline & $7 / 25$ & 21.5 & 17.0 & 13.0 & 22.6 & 30.7 & 23.8 & 9.9 \\
\hline & $8 / 7$ & 21.7 & 14.3 & 12.7 & 38.1 & 27.7 & 16.2 & 5.3 \\
\hline & $8 / 7$ & 23.3 & 15.4 & 7.7 & 26.4 & 38.7 & 17.2 & 10.0 \\
\hline & $7 / 25$ & 25.7 & 18.5 & 6.4 & 16.1 & 28.4 & 32.6 & 16.5 \\
\hline & $8 / 7$ & 28.0 & 17.1 & 4.2 & 20.5 & 31.7 & 32.0 & 11.6 \\
\hline & $7 / 25$ & 28.2 & 19.2 & 5.8 & 11.6 & 26.6 & 31.3 & 24.7 \\
\hline & $8 / 7$ & 31.3 & 17.5 & 4.0 & 13,8 & 28.8 & 31.9 & 21.5 \\
\hline & $8 / 7$ & 33.0 & 18.5 & 1.5 & 11.5 & 19.5 & 39.5 & 28.0 \\
\hline & $8 / 7$ & 35.3 & 19.4 & 0.8 & 5.8 & 16.5 & 40.4 & 36.5 \\
\hline
\end{tabular}

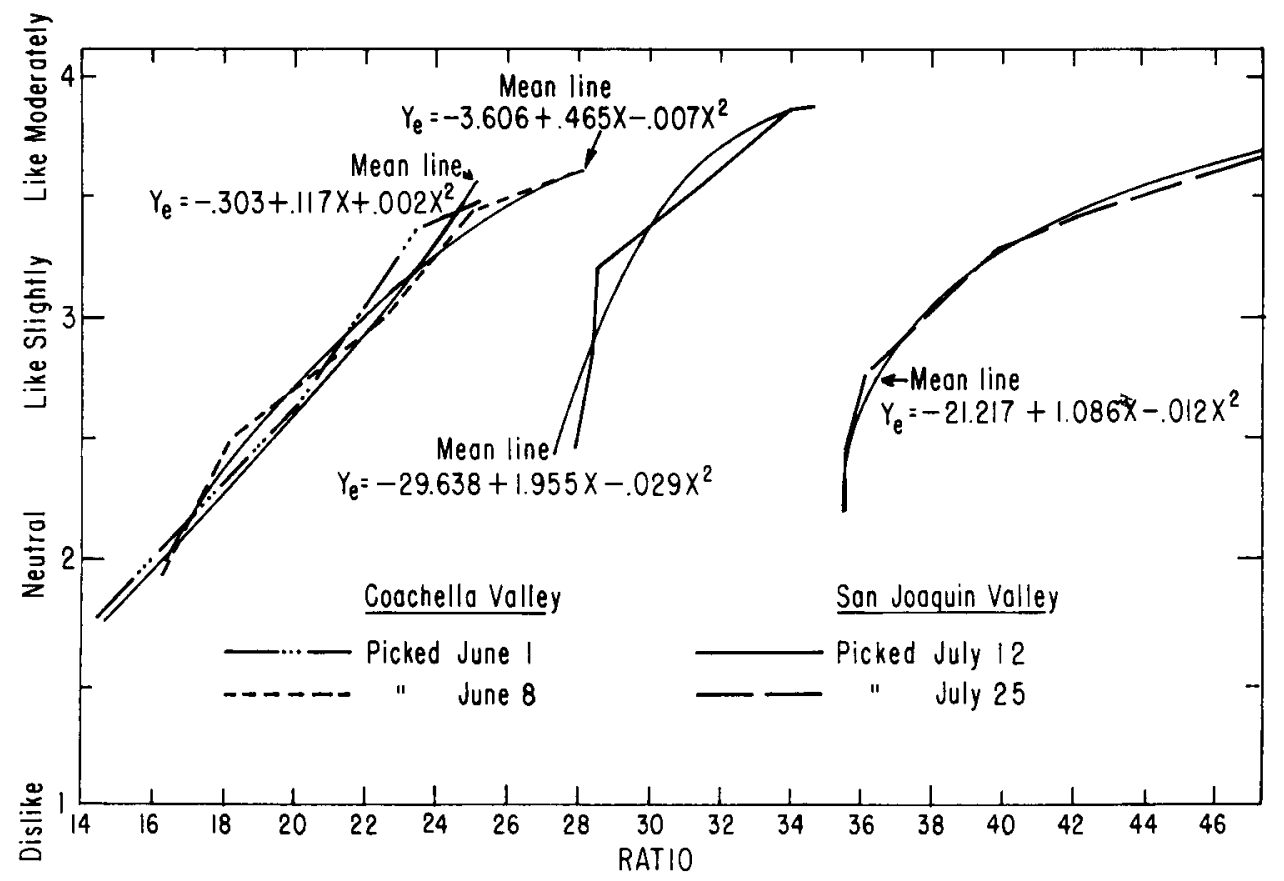

Figure 6. Relationship between taste acceptability and Balling/acid ratio of Cardinal grapes, 1961 
$15.0^{\circ}$ Balling was disliked 54.1 per cent of the time, and that picked on May 31 at the same degree Balling was disliked only 34.0 per cent of the time.

Figure 4 shows the relationship between color acceptability and the Ball. ing/acid ratio. There is a definite increase in acceptability (though much less pronounced than in the case of taste, as is indicated by the slope of the mean line) with increase in the Balling/acid ratio.

\section{Cardinal sensory tests}

Figure 5 shows that acceptability of Cardinal grapes increased with degree Balling. There is a wide difference in acceptance between the first and second sampling from the Coachella Valley at the low degree Balling levels but this difference disappears at the higher levels-apparently as the difference between the acid levels decreases (table 7). The San Joaquin Valley fruit shows the same difference between samplings and this difference persists through the higher Balling levels; in fact it increases beyond $15.5^{\circ}$ Balling until the $17.5^{\circ}$ Balling level is reached. At this point acceptability for the second sampling levels off, with the result that the difference between the first and second samplings decreases rapidly near $18^{\circ}$ Balling.

When the Cardinal data are presented on a ratio rather than on a degree Balling basis, the significance of the acidity as a palatability factor is further emphasized (figure 6). Acceptability of both samplings from the Coachella Valley agreed closely and rose consistently with the ratio. The increase started to level off at a ratio of 25:1, indicating that palatability did not increase much more at higher ratios even in this relatively high-acid range (for Cardinal). Results with the San Joaquin Valley fruit clearly reflected the effect of a low acid range on palatability. The first sampling with an acid content ranging from 0.53 to 0.56 per cent showed a rapid increase in ac- ceptability, with an indication of leveling off at a ratio of $34: 1$. The extreme steepness of the first part of the acceptability line was due to the unusual trend in the acid levels of the series. In this instance the 15.6 and $15.9^{\circ}$ Balling levels showed acid contents slightly higher than the $14.7^{\circ}$ Balling level; by the time the second sampling was made the acid content of the series had dropped about $0.1 \%$ below that of the first-this deerease substantially increased the ratio of the samples but depressed acceptability. It would appear then that the low maturity samples of the Coachella Valley were rated low because of sourness (high acid) and those from the San Joaquin Valley because of flatness (low sugar and acid).

Table 9 also shows the taste acceptability decisions for Cardinal grapes on a percentage basis. There was a wide overlap of the two samplings from the Coachella Valley when the ratios were arranged in ascending order (note intermingling of sampling dates) owing to the small difference between the acid contents of the two samplings. The "dislike" reaction decreases quite consistently as the ratio increases. The San Joaquin Valley samplings show no overlap since the acid ranges were widely separated. The acid content of the lowest degree Balling sample of the second sampling was so low that the ratio exceeded that of the highest degree Balling sample of the first sampling. It is interesting to note that the dislike reaction increases sharply from the last sample of the first sampling to the first sample of the second sampling in spite of a slight increase in the Balling/acid ratio. This anomaly is probably due to the flat insipid character of the higherratio sample. As a matter of fact, under these high-ratio conditions there is a more consistent relationship between taste acceptability and degree Balling than between acceptability and Balling/ acid ratio (figures 5,6 ). Undoubtedly the tasters reacted primarily to the sugar content (degree Balling) when 
Table 10

MINIMUM BALLING/ACID RATIOS OF TABLE GRAPES REQUIRED TO MAINTAIN DISLIKE TASTE DECISIONS BELOW VARIOUS PERCENTAGE LEVELS

\begin{tabular}{|c|c|c|c|c|c|c|}
\hline \multirow{2}{*}{ Variety } & \multirow{2}{*}{$\begin{array}{c}\text { Acid range } \\
\text { (gm tart } / 100 \mathrm{ml})\end{array}$} & \multicolumn{5}{|c|}{ Percentage of dislike decisions } \\
\hline & & 10 & 20 & 30 & 40 & 50 \\
\hline & & \multicolumn{5}{|c|}{ Balling/acid ratio } \\
\hline Perlette. & 0.80 to 1.00 & $20: 1$ & $18: 1$ & $16: 1$ & $15: 1$ & $14: 1$ \\
\hline Cardinal.. & 0.75 to 1.00 & $22: 1$ & $19: 1$ & $18: 1$ & $17: 1$ & $15: 1$ \\
\hline Cardinal...... & 0.50 to 0.60 & $28: 1$ & $28: 1$ & $26: 1$ & $\ldots$ & $\ldots$ \\
\hline Cardinal...... & 0.40 to 0.45 & $36: 1$ & $35: 1$ & $35: 1$ & $\ldots$ & $\ldots$ \\
\hline Thompson Seedless. . & 1.00 to 1.40 & $\ldots$ & $16: 1$ & $15: 1$ & $14: 1$ & $13: 1$ \\
\hline Thompson Seedless............... & 0.90 to 1.00 & $19: 1$ & $17: 1$ & $16: 1$ & $16: 1$ & $16: 1$ \\
\hline Thompson Seedless.............. & 0.80 to 0.80 & $\ldots$ & $21: 1$ & $21: 1$ & $19: 1$ & $18: 1$ \\
\hline Thompson Seedless. . ............. & 0.65 to 0.70 & $22: 1$ & $\ldots$ & $\ldots$ & $\ldots$ & $\ldots$ \\
\hline
\end{tabular}

there was so little total acid present.

The reason for the anomaly of low acceptability of high-ratio grapes with low acidity was clarified somewhat by rearranging some of the data from tables 8 and 9 . From these tables it was possible to secure a sufficient number of samples with chemical and dislike sensory values to demonstrate the effect of the amount of acidity on the Balling/ acid ratio required for specified levels of acceptability. Three levels of acidity for Cardinal and four for Thompson Seedless were included (table 10). In a few instances there were no samples that fulfilled all of the requirements of the criteria - hence the blank spaces. However, it is still clear that the acid content showed a markéd inverse relationship to the Balling/acid ratio for a given level of acceptability. This relationship is particularly pronounced for

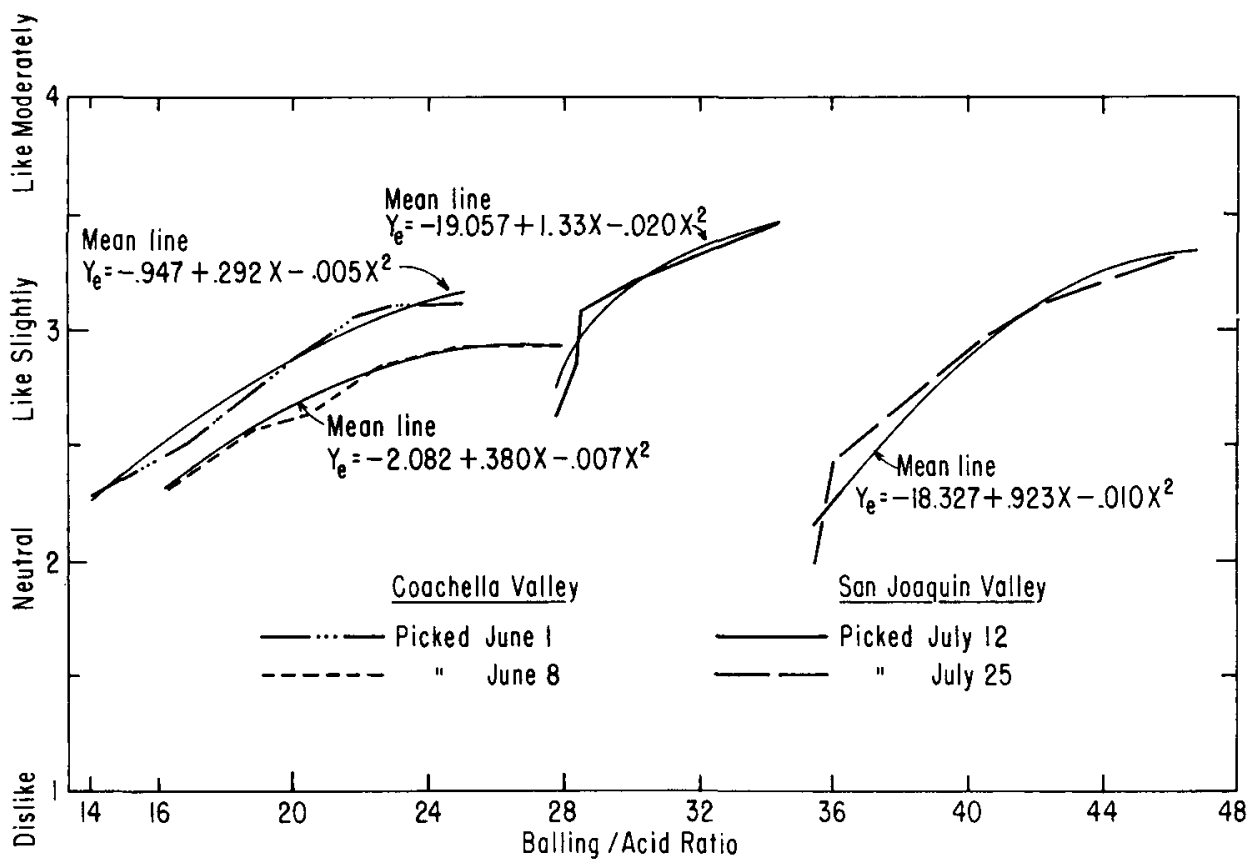

Figure 7. Relationship between color acceptability and Balling/acid ratio of Cardinal grapes, 1961. 
the Cardinal variety owing to the wide range in acidity. Samples in the lowestacid range, with less than half the acid content of those in the high-acid range, have ratios nearly twice as high as those for the high-acid samples.

Table 10 also shows that as the percentage of dislike decisions increased the Balling/acid ratio of the fruit required to meet these sensory standards became lower. To keep the percentage of dislike decisions below 10 per cent for Perlette required fruit with a ratio of 20:1; a ratio of only $14: 1$ was required to keep the dislike value below 50 per cent. The corresponding ratios for Cardinal in the same acid range as the Perlette were slightly higher, while the trend for Thompson Seedless was less pronounced than for either of the other varieties. In the comparable acidity range of 0.9 to 1.00 , the ratios for Thompson Seedless showed a decrease of 3 from the 10 to the 50 per cent dislike levels. At the same time the Perlette ratios decreased 6 , and the Cardinal, 7.

Figure 7 shows the color acceptability data for the Cardinal samples, and it is apparent that there is a strong relation- ship between color acceptability and maturity. The range of acceptability is probably just as large as for taste, since color was rated on a four-point scale rather than the five-point scale used for taste acceptability; in fact, the shape and slope of the acceptability lines are very similar to those for taste. Certainly the panel members showed a more pronounced reaction to color in this variety than to that of the Perlette.

\section{Thompson Seedless sensory tests}

Figure 8 shows the relationship between taste acceptability and the Balling/acid ratio of Thompson Seedless. Acceptability rises consistently with the ratio and shows no evidence of leveling off even at a ratio of $35: 1$. Although there are some wide deviations from the mean line, they are largely in the maturity range below a ratio of 22:1 (still below the acceptability level of "like slightly"). But these deviations appear modest when compared to those shown in figure 9, where acceptability data is related to degree Balling alone. Although there is no mean line, it is apparent that there is a very wide range in

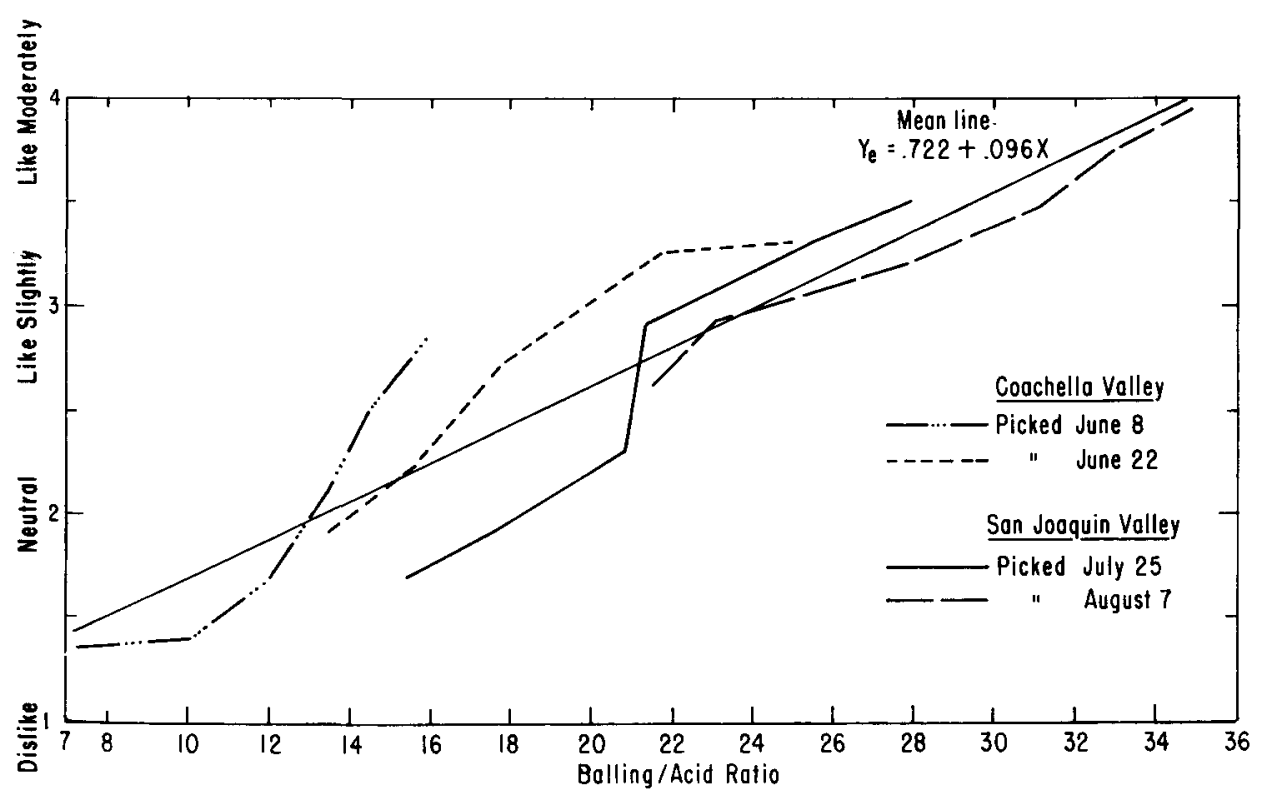

Figure 8. Relationship between taste acceptability and Balling/acid ratio of Thompson Seedless grapes, 1961 


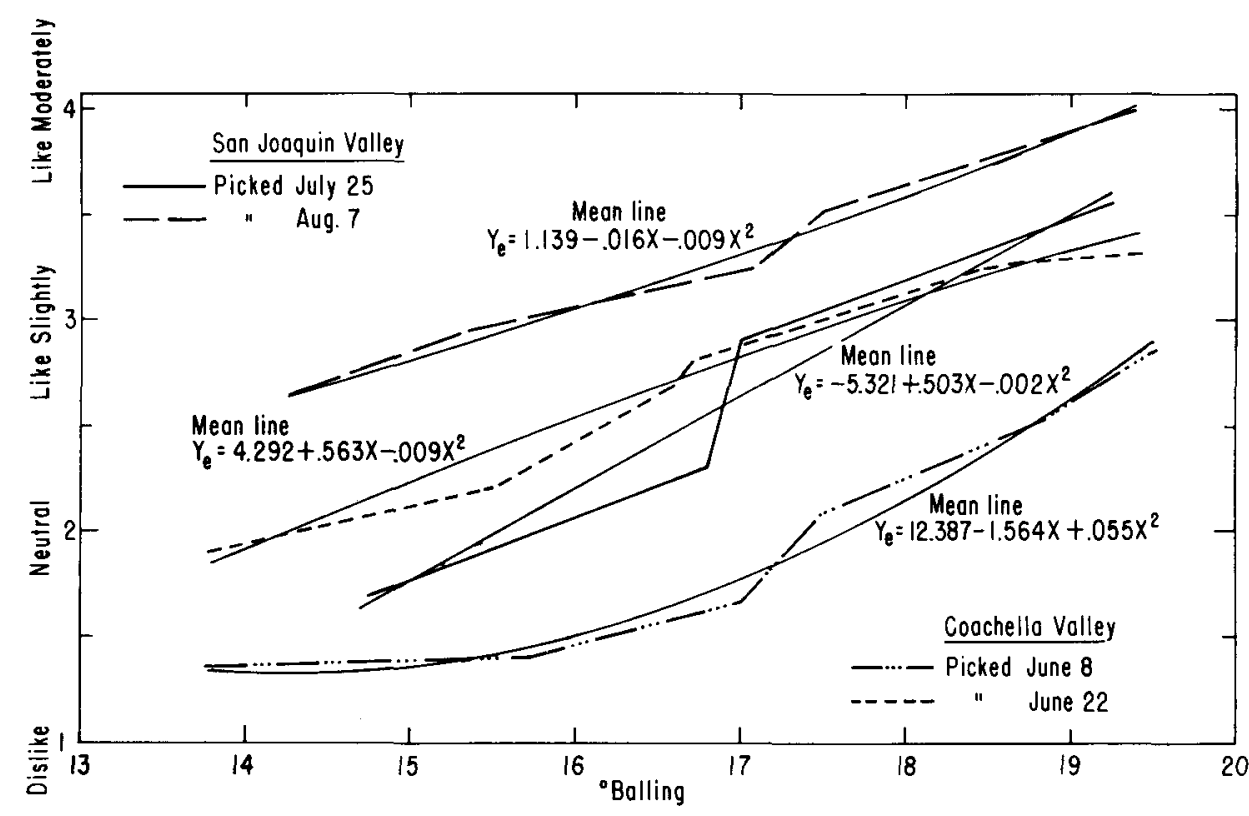

Figure 9. Relationship between taste acceptability and degrees of Balling of Thompson Seedless grapes, 1961

taste acceptability at any degree ity from dislike to higher acceptability Balling level throughout the maturity levels when data are arranged with the range.

The taste acceptability decisions on a ratio in ascending order. It is apparent percentage basis for the Thompson Seedless samples are shown in table 9 . There is a consistent shift in acceptabilthat pronounced inconsistencies would appear if the data were arranged on the basis of degree Balling alone. For example, 80 per cent of the decisions were

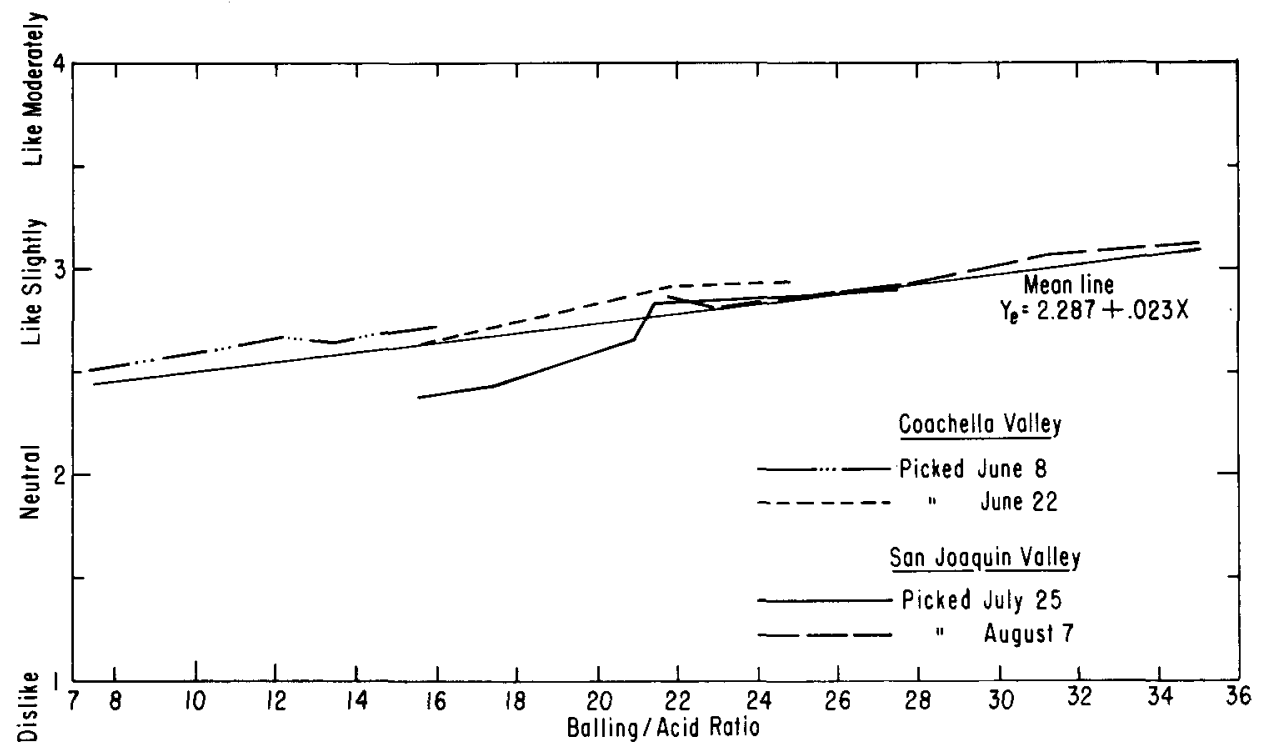

Figure 10. Relationship between color acceptability and Balling/acid ratio of Thompson Seedless grapes, 1961. 
dislike for the $13.8^{\circ}$ Balling sample harvested June 8 in the Coachella Valley, but only 41.9 per cent for the same Balling-level sample harvested June 25.

The wide range in acid content of these samples largely accounts for the great differences in taste acceptability at each Balling level. The acceptability data on this variety along with that from the Cardinals emphasizes the fact that as the acid content increases the Balling/acid ratio becomes progressively a better index of palatability than degree Balling alone.

Figure 10 shows the relationship between color acceptability and the Balling/acid ratio of Thompson Seedless grapes. Although the increase in acceptability with maturity is small, the relationship is significant. These results show that the panel was able to detect the subtle changes in color from green through greenish-yellow to full yellow in the maturity range, and acceptability was correlated with the ratio.
Figure 11 shows the relationship between taste acceptability and Balling/ acid ratio for the regular sensory panel and for the 235 people who acted as a panel on Grape Day in Davis in 1961. The Grape Day panel rated all corresponding samples lower than did the regular panel, indicating proference for sweet grapes. As increase in acceptability with maturity does not level off for either panel, it would be interesting to determine if the slope of the mean line might change at higher levels; this significant aspect is to be studied further.

\section{Nonhomogeneity of tasters}

Baker et al. (1958) have shown that while tasters may be nonhomogeneous in the over-all view, they can be sorted into a comparatively small number of categories.

A preliminary examination of the scoring results of the grape tasters in the present study showed a high degree

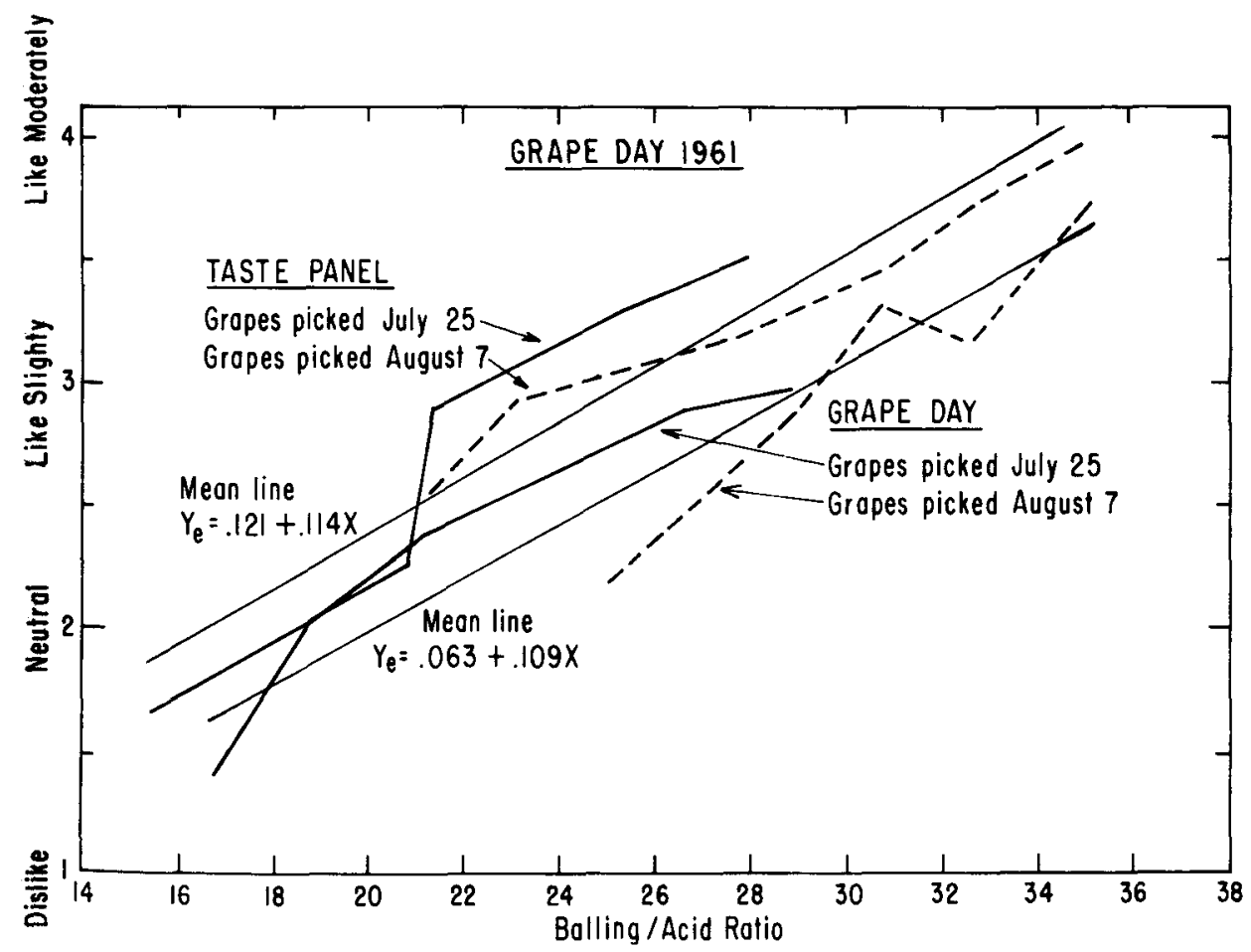

Figure 11. Relationship of taste acceptability to Balling/acid ratio of Thompson Seedless grapes (Davis taste panel and 235 grape-industry members attending Grape Day, 1961). 
of heterogeneity. This is in agreement with Mrak et al. (1959) who found great rariation among individuals' abilities to detect odor differences of phenylethyl alcohol. The usual chisquare test for homogeneity was used in the present study (Snedecor, 1956), and subsequent examination showed that tasters differed greatly in their use of the five-point hedonic scale for scoring taste acceptability, with some using all and some using only part of the range. $\Lambda$ similar four-point scale was used for color acceptability. Results here refer only to the taste scoring, however, as they are more decisive than are those for color.

The taster categories used for this analysis are as follows: I. Full range of five scores; II. Lowest four; III. Highest four; IV. Central three; V. Highest three; VI. Lowest three. These categories include nearly all of the tasters. The groups were not always well defined, and slight deviations were allowed if, for a specific taster, the whole set of tastings (that is, a given variety at a given picking date) indicated a specific category.

Detailed results for these groupings are given in appendix table $A$. The percentage distribution for each category of tasters is given for each degree Balling, Balling/acid ratio, variety, source, and time of harvest. The number of tasters, number of tastings, and significance of chi-square values are also given. The symbol NS means not significant at the 5 per cent level and indicates reasonable conformity among the tasters in the group. A single asterisk indicates some nonconformity, while double asterisks indicate more serious nonconformity. Among such large numbers of chi-square values it is to be expected that some would show significance at the $\mathbf{5}$ per cent level, and even at the 1 per cent level. Not all groupings are perfect, nor do all tasters within the groups react identically, but it does seem clear that the groupings made according to partial use of the range of the rating scale are of practical use, and indicate the extent and character of the heterogeneity.

The importance of the heterogeneity of the tasters is that, by simply mixing the different types of tasters in various proportions, very different over-all assessments are made of different grapetasting experiments. Thus, the discussions in the other sections of this paper apply only to the tasters present in the actual panel used. Extrapolation could be made with more confidence for categories of tasters than for over-all masses of tasters where the different types of tasters are present in unknown proportions.

In table 11 we note that particular tasters can change category as different Ballings, varieties, source and time of harvest are encountered, although there seems to be considerable stability for the category of the tasters.

Very striking differences with respect to the reaction of the tasters to varieties, Balling, Balling/acid ratio, source, and time of harvest are apparent from a serutiny of appendix table $A$. The progressive changes in the frequency distributions of the tasters' scores with change of Balling or Balling/acid ratio are very marked and different for the several categories of tasters.

\section{DISCUSSION AND RECOMMENDATIONS}

The results of this study have shown the superiority of the Balling/acid ratio over degree Balling alone as a method of predicting palatability of table grapes. However, limitations of this method have been indicated, as it does not measure completely the enormous influence of the acid content (or lack of it) on palatability. It is evident (table 10) that the ratio must change inversely with the acid content if it is to have maximum dependability. This suggests that a sliding seale for the ratio would be especially useful to eliminate grapes which are unpalatable because 
they are low in acid content and degree Balling. To accomplish this, the scale could be applied as a supplement to a minimum standard for acid. Grapes failing to pass this minimum could then be subjected to the test of a ratio scaled to the acid content of the fruit in ques- tion. This ratio would be higher than that required for grapes of abovestandard acid, in order to compensate for the lower palatability caused by the sub-standard acid level.

The present study has emphasized the significance of certain problems which

TABLE 11

SIX CATEGORIES OF TASTERS EACH USING A DIFFERENT RANGE OF A 5-POINT HEDONIC SCALE WHEN EVALUATING TASTE ACCEPTABILITY OF GRAPES*

\begin{tabular}{|c|c|c|c|c|c|c|c|c|c|c|c|c|}
\hline \multirow{3}{*}{ Taster number } & \multicolumn{12}{|c|}{ Varietal sample $\dagger$} \\
\hline & \multicolumn{4}{|c|}{ Perlette } & \multicolumn{4}{|c|}{ Cardinal } & \multicolumn{4}{|c|}{ Thompson seedless } \\
\hline & $A$ & B & $\mathrm{G}$ & $\mathrm{H}$ & $\mathrm{C}$ & $\mathbf{D}$ & I & $J$ & $\mathrm{E}$ & $\mathrm{F}$ & $\mathrm{K}$ & $\mathrm{L}$ \\
\hline $1 .$. & II & $\mathbf{I}$ & II & II & I & II & III & III & VI & I & I & III \\
\hline 2. & VI & II & II & II & I & I & $\ddagger$ & II & II & II & II & IV \\
\hline 3 & IV & $\ddagger$ & II & IV & IV & $\ddagger$ & $\ddagger$ & IV & II & IV & IV & IV \\
\hline 4. & I & I & I & I & I & I & I & I & II & I & I & III \\
\hline 5 & VI & VI & VI & II & II & II & III & $\mathrm{V}$ & $\S$ & $\S$ & VI & IV \\
\hline 6.. & VI & VI & $\S$ & $\S$ & II & II & II & IV & VI & VI & II & II \\
\hline 7. & VI & VI & $\S$ & $\S$ & VI & II & $\S$ & $\S$ & $\ddagger$ & VI & $\S$ & $\S$ \\
\hline $8 \ldots$ & II & II & $\S$ & $\S$ & $\mathrm{V}$ & $\mathrm{V}$ & $\mathrm{V}$ & III & I & III & II & III \\
\hline $9 \ldots$ & VI & VI & $\S$ & $\S$ & $\S$ & $\S$ & $\S$ & 8 & $\S$ & $\S$ & $\S$ & $\S$ \\
\hline 10. & vI & VI & II & II & II & II & III & $\mathrm{V}$ & VI & II & I & III \\
\hline 12. & I & I & I & I & I & I & I & I & II & III & I & I \\
\hline 13. & $\S$ & $\S$ & II & I & I & III & III & III & I & I & I & III \\
\hline 15. & VI & VI & VI & II & VI & VI & I & II & $\ddagger$ & VI & I & II \\
\hline $16 \ldots$ & II & II & I & I & II & II & III & I & II & I & I & III \\
\hline $18 \ldots$ & I & $\ddagger$ & II & VI & IV & IV & IV & II & III & II & $\S$ & $\S$ \\
\hline 20 . & $\S$ & $\S$ & II & I & 8 & $\S$ & III & VI & $\S$ & $\S$ & $\S$ & 8 \\
\hline 23. & I & I & II & I & I & I & III & II & I & II & $\S$ & $\S$ \\
\hline 24. & $\S$ & $\S$ & II & I & VI & I & III & I & II & I & I & III \\
\hline 25 . & VI & VI & II & II & VI & VI & II & II & VI & II & I & III \\
\hline $26 \ldots$ & III & III & I & II & $\mathrm{V}$ & $\mathrm{V}$ & V & III & II & I & I & III \\
\hline 29 . & VI & III & VI & VI & II & II & II & VI & VI & II & VI & $\ddagger$ \\
\hline 30. & VI & II & II & II & II & IV & VI & II & VI & VI & VI & $\ddagger$ \\
\hline $31 .$. & II & II & I & I & I & II & I & I & VI & II & II & I \\
\hline $32 \ldots$ & II & IV & $\S$ & $\S$ & II & II & $\S$ & $\$$ & II & II & $\S$ & $\S$ \\
\hline 34. & I & I & II & II & I & I & $\S$ & 8 & II & II & I & II \\
\hline 35. & VI & II & II & II & VI & I & $\S$ & $\S$ & VI & II & $\S$ & $\S$ \\
\hline $36 .$. & VI & VI & II & II & IV & IV & V & V & $\ddagger$ & VI & IV & IV \\
\hline 37. & II & II & I & I & $\S$ & $\S$ & V & I & I & I & I & III \\
\hline $39 .$. & $\S$ & $\S$ & VI & II & V & $\ddagger$ & $\S$ & $\S$ & VI & IV & II & II \\
\hline $40 \ldots$ & $\S$ & $\S$ & $\S$ & $\S$ & II & II & $\S$ & 8 & VI & $\ddagger$ & $\S$ & $\S$ \\
\hline $41 .$. & $\S$ & $\S$ & II & II & II & II & VI & VI & $\ddagger$ & VI & VI & VI \\
\hline 42. & $\S$ & $\S$ & II & II & VI & VI & II & VI & II & II & VI & $\ddagger$ \\
\hline 43.. & $\S$ & $\S$ & I & I & IV & IV & III & I & I & III & I & I \\
\hline 45. & $\S$ & $\S$ & $\S$ & $\S$ & IV & IV & IV & II & VI & II & IV & II \\
\hline $47 .$. & $\S$ & $\S$ & II & I & $\S$ & $\S$ & III & II & $\ddagger$ & VI & II & III \\
\hline 49. & $\S$ & $\S$ & II & I & $\S$ & $\S$ & I & I & VI & I & I & I \\
\hline 52. & $\S$ & $\S$ & $\ddagger$ & VI & $\S$ & $\S$ & $V$ & $\mathrm{~V}$ & $\S$ & $\S$ & II & I \\
\hline 53. & $\S$ & $\S$ & VI & $\S$ & $\S$ & $\S$ & III & $\mathrm{V}$ & $\S$ & $\S$ & $\S$ & $\S$ \\
\hline 54.. & $\S$ & $\S$ & VI & IV & $\S$ & $\S$ & $\S$ & $\S$ & 8 & $\S$ & II & I \\
\hline $55 .$. & $\S$ & $\S$ & $\S$ & $\S$ & $\S$ & $\S$ & I & I & $\S$ & $\S$ & II & I \\
\hline 56. & $\S$ & $\S$ & $\S$ & $\S$ & IV & $\ddagger$ & $\S$ & $\S$ & $\S$ & $\S$ & I & III \\
\hline $57 \ldots$ & $\S$ & $\S$ & $\S$ & $\S$ & $\S$ & $\S$ & $\S$ & $\S$ & $\S$ & $\S$ & I & III \\
\hline
\end{tabular}

* Taste categories are: $I$ = full range of five scores; II = lowest four; III = highest four; IV = central three; V = highest three; VI = lowest three.

† Samples A, C, E are first samplings Coachella Valley; B, D, F, are second samplings Coachella Valley; G, I, K are first samplings San Joaquin Valley; H, J, L, are second samplings San Joaquin Valley.

$\$$ Taster failed to qualify in any of the six categories.

$\$$ Insufficient data. 
may be encountered in cstablishing reliable maturity standards for table grapes. In the first place, there is wide variability in the chemical composition of the fruit, particularly from a sensory standpoint when the individual berry is the unit on which taste impressions are based. Wide variations among berries in both sugar and acid content are usual and both constituents are vitally significant in the over-all taste reaction. In the second place, there is wide variability among indiriduals with respect to taste preferences. Some are very tolerant of acid, others are not,and this also applies to sweetness. As a result, wherever any minimum standard of quality is set (at least within very wide limits of chemical composition of the grapes) some individuals will react favorably and others unfavorably to fruit at that minimum standard level. The level at which this standard is established will be indicated by the number of individuals who, it is felt, can be tolerated in the "unfavorable" sensory category.

No abrupt changes or gaps were apparent in the trends of the chemicalsensory relationship where minimum standard specifications could be clearly set off. As a result, the place where any minimum maturity standard is established on the scale of chemical composition of the fruit will be very arbitrary.

Variability among berries of the cluster creates certain problems in relating their composition to a maturity standard. It should be stressed that any practical maturity measurement applied to grapes must be on a composite sample basis (an individual eluster of grapes is such a sample, if we consider the individual berry as the smallest possible sample). Consequently, the minimum standard determined on a cluster basis must be above the absolute minimum established for the variety, otherwise part of the berries will be below that standard. It is evident (fig. 1 ) that if the average soluble solids content of a cluster is $17^{\circ}$ Balling then half of the berries will be below this level. If the average is $17.5^{\circ}$ Balling, about 32 per cent of the berries will still be below $17^{\circ}$ Balling; if $18^{\circ}$ Balling, about 18 per cent will be below; if $18.5^{\circ}$ Balling, about 10 per cent; and at $19^{\circ}$ Balling about 5 per cent will still be below $17^{\circ}$ Balling. It is apparent that the percentage of fruit that can be allowed below the absolute minimum standard will determine how much above this absolute minimum the cluster sample standard must be placed. The maturity levels of the samples used in the 1961 studies of this paper were more nearly absolute values, as refined methods of sample preparation eliminated much of the variability normally present among berries within a cluster.

\section{SUMMARY}

Chemical and sensory variability studies were made with Perlette, Cardinal, Thompson Seedless, Ribier and Tokay grapes in determining the relationship of maturity to sensory acceptability. Berries within a cluster varied so widely in degree Balling and total acid that critical tests correlating maturity with sensory acceptability were seriously hampered. Only 30 to 50 per cent of the berries were within $\pm 0.5^{\circ}$, and 55 to 85 per cent were within $\pm 1.0^{\circ}$ Balling of the average for the cluster-a major problem of sample variability when the individual berry must be the test unit. Variability was higher in the seeded than seedless varieties because of the strong inverse relationship between berry size and degree Balling. Total acid content was inversely related to degree Balling in composite samples, but varied widely-by as much as 100 per cent-among berries at the same degree Balling.

Clusters of grapes for sensory tests were segregated into four maturity levels $1^{\circ}$ Balling apart on the basis of the average degree Balling of 3-6 per cent of the berries of each cluster, using a hand refractometer. Berry samples of 
the fruit were judged by a sensory panel for color acceptability under white light and for taste acceptability under red and white light. A four-point hedonic scale was used for color and a five-point scale for taste acceptability.

There was no significant relationship between maturity and color acceptability for Perlette grapes. The relationship was significant for Thompson Seedless only at the lowest maturity level. The relationship was significant at all levels for Cardinal. Taste acceptability increased with maturity for all of the varieties. Taste scores were about the same for red and white light. Individual tasters varied widely in level of acceptability-some rated the grapes high throughout the maturity range, others low, and some scores showed a pronounced increase with maturity. Many tasters also showed a strong preference for certain varieties.

Additional studies were made with grape samples of greater uniformity. The individual berries were segregated into maturity lots on a specific gravity basis using sucrose solutions $1^{\circ}$ Balling apart. With this technique, 85 to 95 per cent of the berries were within $\pm 1.0^{\circ}$ Balling of the average of the lot.

Two samplings 1 to 2 weeks apart were made of Perlette, Thompson Seedless and Cardinal grapes, with the first sampling being consistently higher in acid content than the second. Six maturity levels from 14 to $19^{\circ}$ Balling were prepared from each sampling; thus, for both samplings, 12 samples each with a different Balling/acid ratio were available to panel members at each sitting, one sample at a time.

As a result of considerably less variability in samples, there was now a significant increase in color acceptability with maturity-slight for Perlette and Thompson Seedless but pronounced for Cardinal. For taste, the increase was pronounced for all three varieties.

The Balling/acid ratio was a much better index with which to predict acceptability than was degree Balling alone. However, low-acid grapes required a higher ratio than high-acid grapes for a given level of acceptability.

Tasters could be divided into six rather distinct categories depending upon the portion of the five-point hedonic scale used. These tasters were fairly stable within their category as different maturity levels, varieties, source of samples and time of sampling were encountered.

\section{ACKNOWLEDGMENTS}

The authors wish to extend their thanks to the members of the staff of the University who participated in the sensory tests. The careful assistance of those staff members who collected, prepared, and analyzed the samples and supervised the sensory testing is also gratefully acknowledged, particularly that of Mr. Eric Arnold, Mr. Walter Winton, Mr. George Root, Miss Eliza- beth Shapkin, Mr. Cornelius Ough and Mr. Makover Shraga. We are also indebted to Mr. Harold Angier and Mr. Allen Mills of the California Grape and Tree Fruit League for their frequent encouragement during the course of this study. We are especially indebted to the many growers and shippers of the League who donated most of the fruit used in the sensory and chemical tests. 


\section{LITERATURE CITED}

Amerine, M. A., and G. Thoukis

1958. The glucose-fructose ratio of California grapes. Vitis 1:224-29.

AMERine, M. A., and A. J. Winkler

1942. Maturity studies with California grapes. II. The titratable acidity, pH, and organic acid content. Proc. Amer. Soc. Hort. Sci. 40:313-24.

BAKer, G. A., V. MrAK, and M. A. A MERine

1958. Errors of the second kind in an acid threshold test. Food Research $23: 150-54$.

BELL, H. P.

1955. Preferences for camned grapefruit juices. Proc. Fla. State Hort. Soc. 68:151-5j.

Bioletet, F. T.

1925. The basis of grape standardization. Calif. Agr. Exp. Sta. Cir. 293:1-16.

California, Laws and Statutes

1915. California Statutes and Amendments to the Codes, 1915, Chap. 659 (pertaining to the Fruit, Nut and Vegetable Standardization Act, 1915), Sacramento, Calif.

1959a. Agricultural Code, Bureau of Fruit and Vegetable Standardization, Dept. of Agr. Seetions 795.1, 796.0.

1959b. Agricultural Code, Bureau of Fruit and Vegetable Standardization, Dept. of Agr. Section 802.

Dalmasso, G., and M. Venezia

1937. Il controllo del grado di maturita delle uve da tavola e l'applicazione del rifrattometro. Annuario Staz. Sperm. Vitic. e Enol., Conegliano 7:339-96.

Florida, Laws and Statutes

1949. Florida Citrus Code of 1949, Senate Bill 123, Chap. 25149 (No. 153), Sections 16-22, Tallahassee, Florida.

1961. Citrus fruit laws, Florida Citrus Code, Chap. 601, Sections 601.16-601.232, Florida Citrus Commission, Lakeland, Florida.

Gurmon, J. F., and C. S. OUGH

1962. A uniform method for total acid determination in wines, Amer. J. Enol, and Vitic. $13: 40-45$.

Huahes, E., and E. Bouffard

1937. Sur le degreé de maturité des raisins de table. Ann. fals. et fraudes 30:91-94.

KENDALL, M. G.

1955. The advanced theory of statisties. 3 edit., Hafner Pub. Co., New York.

KILBURN, R. W.

1958. The taste of citrus juice. I. Relationship between Brix, acid, and pH. Proc. Fla. State Hort. Soc. 71:251-54.

MoRse, R. L. D.

1954. Consumer preferences for canned orange juice of 12 to 22 Brix/acid ratios. Proc. Fla. State Hort. Soc. $67: 186-92$.

Mrak, V., M. A. Amerine, C. S. Ough, and G. A. Baker

1959. Odor difference test with applications to consumer preferences. Food Research 24:574-78.

NEDELCHEV, N., and M. KONDAREV

1934. Maturity standards for the Chaouch and Dattier de Beyruth grapes (transl.). Ann. Univ. Sofia, Faeulty Agron. et Sylvic. 12:487-504.

SNEDECOR, G. W.

1956. Statistical methods. 5 edit., Ames, Iowa, State College Press.

U. S. Code of Federal Regulations

1959. Brine flotation test for separating peas according to maturity. Title 7, Agriculture, Sections 52.2291, 52.2292.

1962. Standards for grades of table grapes (European or Vinifera type). Title 7, Agriculture, Sections 51.880-51.912.

WestrRooK, G. F., and E. C. Stenstrom

1956. A study of the degree Brix and Brix/acid ratios of grapefruit utilized by Florida citrus processors for the seasons 1952-1953 through 1955-1956. Proc. Fla. State Hort. Soc. $69: 113-120$.

1957. A study of the degree Brix and Brix/acid ratios of oranges utilized by Florida proces. sors for the seasons 1952-1953 through 1956-1957. Proc. Fla. State Hort. Soc. 70:247-59.

WINKLER, A. J.

1932. Maturity tests for table grapes. Calif. Agr. Exp. Sta. Bul. 529:1-35.

1948. Maturity tests for table grapes - the relation of heat summation to time of maturing and palatability. Proc. Amer. Soc. Hort. Sci. 51:295-98. 


\section{APPENDIX}

Appendix Table A

CATEGORIES OF GRAPE TASTERS BASED ON THE PORTION OF A 5-POINT HEDONIC SCALE USED, INCLUDING PERCENTAGE DISTRIBUTION

OF SCORES

\begin{tabular}{|c|c|c|c|c|c|c|c|c|c|}
\hline \multicolumn{10}{|c|}{ Category $I^{*}$} \\
\hline \multirow{2}{*}{$\begin{array}{c}\text { Variety and } \\
\text { sample number }\end{array}$} & \multirow{2}{*}{$\begin{array}{c}\text { Balling/acid } \\
\text { ratio }\end{array}$} & \multirow{2}{*}{$\begin{array}{c}\text { Number } \\
\text { of } \\
\text { tasters }\end{array}$} & \multirow{2}{*}{$\begin{array}{l}\text { Number } \\
\text { of } \\
\text { tastings }\end{array}$} & \multicolumn{5}{|c|}{ Taste scale } & \multirow{2}{*}{$\begin{array}{l}\text { Signifi- } \\
\text { cance }\end{array}$} \\
\hline & & & & 1 & 2 & 3 & 4 & 5 & \\
\hline \multicolumn{10}{|l|}{ Perlette: } \\
\hline $14 \mathrm{~A}$ & 12.28 & 5 & 24 & .6667 & .2083 & .0000 & .1250 & .0000 & NS \\
\hline $14 \mathrm{~B} \ldots$ & 14.95 & 5 & 24 & .4167 & .3333 & .2083 & .0417 & .0000 & NS \\
\hline $14 \mathrm{G} \ldots \ldots$ & 9.70 & 7 & 67 & .7910 & .1045 & .0746 & .0299 & .0000 & NS \\
\hline $14 \mathrm{H} \ldots$ & 14.34 & 12 & 106 & .4906 & .3396 & .1415 & .0283 & .0000 & NS \\
\hline \multicolumn{10}{|l|}{ Cardinal: } \\
\hline $14 \mathrm{C} \ldots$ & 14.55 & 8 & 47 & .6383 & .2128 & .0851 & .0638 & .0000 & NS \\
\hline $14 \mathrm{D} \ldots$ & 16.18 & 7 & 43 & .3953 & .4186 & .1163 & .0698 & .0000 & NS \\
\hline $14 \mathrm{I} \ldots \ldots \ldots \ldots \ldots$ & 27.74 & 6 & 40 & .4000 & .2750 & .2500 & .0750 & .0000 & NS \\
\hline $14 \mathrm{~J} \ldots \ldots \ldots$ & 35.64 & 9 & 56 & .3214 & .3750 & .1786 & .1071 & .0179 & NS \\
\hline \multicolumn{10}{|l|}{ Thompson Seedless: } \\
\hline $14 \mathrm{E} \ldots \ldots \ldots \ldots$ & 7.19 & 5 & 32 & .8125 & .0625 & .1250 & .0000 & .0000 & NS \\
\hline $14 \mathrm{~F} \ldots \ldots \ldots \ldots \ldots$ & 13.53 & 8 & 45 & .3111 & .4667 & .1333 & .0445 & .0444 & NS \\
\hline $14 \mathrm{~K} \ldots \ldots \ldots \ldots$ & 15.47 & 17 & 141 & .6312 & .1844 & .1206 & .0496 & .0142 & $*$ \\
\hline $14 \mathrm{~L} \ldots \ldots \ldots \ldots$ & 21.67 & 6 & 51 & .2549 & .1569 & .3333 & .1961 & .0588 & NS \\
\hline \multicolumn{10}{|l|}{ Perlette: } \\
\hline $15 \mathrm{~A} \ldots \ldots$ & 13.39 & 5 & 29 & .4828 & .1379 & .2414 & .1034 & .0345 & NS \\
\hline $15 \mathrm{~B}, \ldots \ldots \ldots \ldots$ & 17.05 & 5 & 28 & .2857 & .1429 & .2500 & .2500 & .0714 & NS \\
\hline $15 \mathrm{G} \ldots \ldots \ldots \ldots \ldots$ & 13.88 & 7 & 67 & .3582 & .2090 & .3134 & .1045 & .0149 & NS \\
\hline $15 \mathrm{H} \ldots$ & 16.78 & 12 & 105 & .2762 & .2667 & .2857 & .1333 & .0381 & NS \\
\hline \multicolumn{10}{|l|}{ Cardinal: } \\
\hline $15 \mathrm{C} \ldots$ & 17.42 & 8 & 47 & .4043 & .2553 & .2340 & .0426 & .0638 & NS \\
\hline $15 \mathrm{D} \ldots \ldots$ & 18.14 & 7 & 42 & .3095 & .3095 & .1905 & .0953 & .0953 & NS \\
\hline $15 \mathrm{I} \ldots \ldots \ldots \ldots \ldots$ & 28.36 & 6 & 40 & .3000 & .1500 & .2250 & .2500 & .0750 & NS \\
\hline $15 \mathrm{~J} \ldots \ldots \ldots \ldots \ldots$ & 35.58 & 9 & 56 & .2143 & .4107 & 1607 & .1250 & .0893 & NS \\
\hline \multicolumn{10}{|l|}{ Thompson Seedless: } \\
\hline $15 \mathrm{E} \ldots \ldots \ldots \ldots$ & 10.19 & 5 & 32 & .5625 & .1562 & .2188 & .0625 & .0000 & NS \\
\hline 15 F.............. & 15.66 & 8 & 46 & .2174 & .3478 & .2609 & .1522 & .0217 & NS \\
\hline $15 \mathrm{~K}$. & 17.61 & 17 & 141 & .4681 & .2127 & .2057 & .0993 & .0142 & NS \\
\hline $15 \mathrm{~L} \ldots \ldots$ & 23.33 & 16 & 51 & .0980 & .0784 & .3922 & .2745 & .1569 & NS \\
\hline \multicolumn{10}{|l|}{ Perlette: } \\
\hline $16 \mathrm{~A} \ldots \ldots$ & 14.27 & 5 & 29 & .2414 & .3103 & .3103 & .0690 & .0690 & NS \\
\hline $16 \mathrm{~B} \ldots \ldots \ldots \ldots \ldots$ & 18.26 & 5 & 28 & .1429 & .2143 & .2857 & .2500 & .1071 & NS \\
\hline $16 \mathrm{G} \ldots \ldots \ldots \ldots \ldots$ & 18.43 & 7 & 67 & .0746 & .1045 & .3134 & .3582 & .1493 & NS \\
\hline $16 \mathrm{H} . \ldots$ & 18.75 & 12 & 106 & .1038 & .1792 & .3302 & 2925 & .0943 & NS \\
\hline \multicolumn{10}{|l|}{ Cardinal: } \\
\hline $16 \mathrm{C} \ldots \ldots$ & 20.00 & 8 & 47 & .2553 & .2128 & .2553 & .1915 & .0851 & NS \\
\hline $16 \mathrm{D} \ldots \ldots \ldots \ldots \ldots$ & 20.51 & 7 & 43 & .0930 & .3488 & .2558 & .2094 & .0930 & NS \\
\hline $16 \mathrm{I} \ldots \ldots \ldots \ldots$ & 28.39 & 6 & 40 & .0250 & .1750 & .4250 & .3000 & .0750 & $*$ \\
\hline $16 \mathrm{~J} \ldots \ldots \ldots \ldots \ldots$ & 36.14 & 9 & 56 & .1071 & .2679 & .3571 & .1429 & .1250 & NS \\
\hline \multicolumn{10}{|l|}{ Thompson Seedless: } \\
\hline $16 \mathrm{E} \ldots \ldots \ldots \ldots$ & 12.06 & 5 & 32 & .4062 & .3125 & .2500 & .0000 & .0313 & NS \\
\hline $16 \mathrm{~F} \ldots \ldots$ & 17.66 & 8 & 46 & .1304 & .1522 & .2609 & .3261 & .1304 & NS \\
\hline $16 \mathrm{~K} \ldots \ldots \ldots$ & 21.00 & 17 & 142 & .2817 & .2254 & .2958 & .1549 & .0422 & NS \\
\hline $16 \mathrm{~L} \ldots \ldots \ldots$ & 28.03 & 6 & 51 & .1569 & .0588 & .2549 & .3725 & .1569 & NS \\
\hline \multicolumn{10}{|l|}{ Perlette: } \\
\hline $17 \mathrm{~A} \ldots \ldots$ & 15.73 & 5 & 29 & .1724 & .1724 & .4828 & .1034 & .0690 & NS \\
\hline $17 \mathrm{~B} \ldots \ldots$ & 20.24 & 5 & 28 & .1428 & .1429 & .2500 & .1786 & .2857 & NS \\
\hline $17 \mathrm{G} \ldots \ldots \ldots$ & 22.78 & 7 & 27 & .0299 & .1493 & .1791 & .3731 & .2686 & NS \\
\hline $17 \mathrm{H} \ldots \ldots \ldots \ldots$ & 23.01 & 12 & 106 & .0189 & .1038 & .2264 & .4811 & .1698 & NS \\
\hline
\end{tabular}

* All categories based on the portion of the 5-point hedonic scale consistently used by each taster as follows: $I=$ full range of five scores; II = lowest four; III = highest four; IV = central three; $V=$ highest three; VI $=$ lowest three. inS means not significant at the 5 per cent level. Single asterisk indicates some nonconformity. Double asterisks 
Appendix Table A-Continued

\begin{tabular}{|c|c|c|c|c|c|c|c|c|c|}
\hline \multicolumn{9}{|c|}{ Category I-Continued } & \\
\hline \multirow{2}{*}{$\begin{array}{l}\text { Variety and } \\
\text { sample number }\end{array}$} & \multirow{2}{*}{$\underset{\text { ratio }}{\text { Balling/acid }}$} & \multirow{2}{*}{$\begin{array}{c}\text { Number } \\
\text { of } \\
\text { tasters }\end{array}$} & \multirow{2}{*}{$\begin{array}{c}\text { Number } \\
\text { of } \\
\text { tastings }\end{array}$} & \multicolumn{4}{|c|}{ Taste scale } & \multirow[b]{2}{*}{5} & \multirow{2}{*}{$\begin{array}{l}\text { Signifi- } \\
\text { cance }\end{array}$} \\
\hline & & & & 1 & 2 & 3 & 4 & & \\
\hline \multicolumn{10}{|l|}{ Cardinal: } \\
\hline $17 \mathrm{C} \ldots$ & 22.05 & 8 & 47 & .1277 & .0638 & .3404 & .2553 & .2128 & $* *$ \\
\hline $17 \mathrm{D} \ldots$ & 22.44 & 7 & 42 & .0952 & .2619 & .3095 & .2143 & .1191 & $* *$ \\
\hline $17 \mathrm{I} \ldots$ & 31.32 & 6 & 40 & .1000 & .0750 & .2250 & .3750 & .2250 & NS \\
\hline $17 \mathrm{~J}, \ldots$ & 39.55 & 9 & 56 & .1250 & .1428 & .2143 & .3036 & .2143 & NS \\
\hline \multicolumn{10}{|l|}{ Thompson Seedless: } \\
\hline $17 \mathbf{E} \ldots \ldots \ldots \ldots \ldots$ & 13.46 & 5 & 32 & .2188 & .2187 & .3125 & .1875 & .0625 & $*$ \\
\hline $17 \mathbf{F}$ & 19.45 & 8 & 46 & .1087 & .2174 & .2174 & .2391 & .2174 & NS \\
\hline $17 \mathrm{~K} \ldots$ & 21.52 & 17 & 142 & .1056 & .2183 & .2817 & .2395 & .1549 & NS \\
\hline $17 \mathrm{~L} \ldots$ & 31.25 & 6 & 51 & .1176 & .0392 & .2549 & .3922 & .1961 & NS \\
\hline \multicolumn{10}{|l|}{ Perlette: } \\
\hline $18 \mathrm{~A} \ldots$ & 17.73 & 5 & 29 & .2069 & .1034 & .3449 & .2069 & .1379 & NS \\
\hline $18 \mathbf{B} \ldots \ldots \ldots \ldots$ & 22.50 & 5 & 28 & .0357 & .1071 & .1072 & .3571 & .3929 & NS \\
\hline $18 \mathrm{G} \ldots \ldots \ldots \ldots$ & 26.12 & 7 & 67 & .0149 & .1194 & .0597 & .4776 & .3284 & $* *$ \\
\hline $18 \mathrm{H} \ldots \ldots \ldots \ldots \ldots$ & 25.36 & 12 & 104 & .0096 & .0192 & .2116 & $.432 \bar{T}$ & .3269 & NS \\
\hline \multicolumn{10}{|l|}{ Cardinal: } \\
\hline $18 \mathrm{C} \ldots$ & 23.55 & 8 & 46 & .0652 & .0435 & .1304 & .3696 & .3913 & NS \\
\hline $18 \mathrm{D} \ldots$ & 24.86 & 7 & 43 & .0698 & .0698 & .1395 & .3488 & .3721 & $* *$ \\
\hline $18 \mathrm{I}$. & 34.04 & 6 & 40 & .0250 & .0000 & .1000 & .3750 & .5000 & NS \\
\hline $18 \mathrm{~J}$ & 42.14 & 9 & 56 & .0357 & .0000 & .1964 & .4107 & .3572 & NS \\
\hline \multicolumn{10}{|l|}{ Thompson Seedless: } \\
\hline $18 \mathrm{E} \ldots \ldots$ & 14.50 & 5 & 31 & .0645 & .1613 & .2581 & .2903 & .2258 & NS \\
\hline $18 \mathbf{F} \ldots \ldots \ldots \ldots \ldots$ & 21.76 & 8 & 46 & .0434 & .1087 & .1522 & .4348 & .2609 & NS \\
\hline $18 \mathrm{~K} \ldots \ldots \ldots \ldots$ & 25.69 & 17 & 142 & .0352 & .1268 & .2254 & .3239 & .2887 & NS \\
\hline $18 \mathrm{~L} \ldots \ldots$ & 33.04 & 6 & 51 & .0392 & .0392 & .0785 & .5490 & .2941 & NS \\
\hline \multicolumn{10}{|l|}{ Perlette: } \\
\hline $19 \mathrm{~A}$. & 19.27 & 5 & 29 & .0690 & .2069 & .1035 & .3103 & .3103 & NS \\
\hline $19 \mathrm{~B} \ldots$ & 23.85 & 5 & 28 & .0000 & .0000 & .1071 & .4286 & .4643 & NS \\
\hline \multicolumn{10}{|l|}{ Cardinal: } \\
\hline $19 \mathrm{C} \ldots \ldots$ & 25.06 & 8 & 46 & .0652 & .0652 & .1304 & .4131 & .3261 & NS \\
\hline $19 \mathrm{D} \ldots \ldots$ & 28.12 & 7 & 42 & .0000 & .0714 & .1667 & .4524 & .3095 & * \\
\hline $19 \mathrm{I}$. & 34.53 & 6 & 40 & .0250 & .0750 & .0750 & .3750 & .4500 & $*$ \\
\hline $19 \mathrm{~J} \ldots \ldots \ldots \ldots \ldots$ & 46.92 & 9 & 55 & .0545 & .0182 & .1273 & .3455 & .4545 & NS \\
\hline \multicolumn{10}{|l|}{ Thompson Seedless: } \\
\hline $19 \mathrm{E} \ldots \ldots \ldots \ldots \ldots$ & 16.12 & 5 & 32 & .0625 & .0313 & .1875 & .4062 & .3125 & NS \\
\hline $19 \mathrm{~F} \ldots \ldots \ldots$ & 24.87 & 8 & 46 & .0435 & .0652 & .1957 & .3043 & .3913 & NS \\
\hline $19 \mathrm{~K} \ldots \ldots \ldots$ & 28.24 & 17 & 142 & .0493 & .0634 & .1408 & .3310 & .4155 & NS \\
\hline $19 \mathrm{~L} \ldots \ldots \ldots \ldots$ & 35.27 & 6 & 51 & .0196 & .0196 & .0980 & .3530 & .5098 & ** \\
\hline
\end{tabular}

* All categories based on the portion of the 5-point hedonic scale consistently used by each taster as follows: $I=$ ful range of five scores; II = lowest four; III = highest four; IV = central three; V = highest three; VI = lowest three. $\dagger$ NS means not significant at the 5 per cent level. Single asterisk indicates some nonconformity. Double asterisks indicate more serious nonconformity. 
Appendix Table A-Continued

\begin{tabular}{|c|c|c|c|c|c|c|c|c|}
\hline \multicolumn{9}{|c|}{ Category II* $^{*}$} \\
\hline \multirow{2}{*}{$\begin{array}{l}\text { Variety and } \\
\text { sample number }\end{array}$} & \multirow{2}{*}{$\underset{\text { ratio }}{\text { Balling/acid }}$} & \multirow{2}{*}{$\begin{array}{c}\text { Number } \\
\text { of } \\
\text { tasters }\end{array}$} & \multirow{2}{*}{$\begin{array}{c}\text { Number } \\
\text { of } \\
\text { tastings }\end{array}$} & \multicolumn{4}{|c|}{ Taste scale } & \multirow{2}{*}{$\begin{array}{l}\text { Signifi- } \\
\text { cance } \dagger\end{array}$} \\
\hline & & & & 1 & 2 & 3 & 4 & \\
\hline \multicolumn{9}{|l|}{ Perlette: } \\
\hline $\begin{array}{l}14 \mathrm{~A} \ldots \\
14 \mathrm{~B} \ldots\end{array}$ & 12.28 & 6 & 24 & .7500 & $\begin{array}{r}.2083 \\
3448\end{array}$ & $\begin{array}{r}.0417 \\
.379\end{array}$ & .0000 & NS \\
\hline $\begin{array}{l}14 \mathrm{~B} \ldots \\
14 \mathrm{G} \ldots\end{array}$ & $\begin{array}{r}14.95 \\
9.70\end{array}$ & $\begin{array}{r}7 \\
18\end{array}$ & $\begin{array}{r}29 \\
138\end{array}$ & $\begin{array}{l}.448 \tilde{a} \\
.7174\end{array}$ & $\begin{array}{r}.3448 \\
2174\end{array}$ & $\begin{array}{l}.1379 \\
.0217\end{array}$ & $\begin{array}{r}.0690 \\
.0435\end{array}$ & $\begin{array}{l}\mathrm{NS} \\
* *\end{array}$ \\
\hline $\begin{array}{l}14 \mathrm{G} \ldots \\
14 \mathrm{H} \ldots\end{array}$ & $\begin{array}{r}9.70 \\
14.34\end{array}$ & $\begin{array}{l}18 \\
14\end{array}$ & $\begin{array}{l}138 \\
102\end{array}$ & $\begin{array}{l}.6114 \\
.6078\end{array}$ & $\begin{array}{l}.2174 \\
.3530\end{array}$ & .0294 & .0098 & NS \\
\hline \multicolumn{9}{|l|}{ Cardinal: } \\
\hline $14 \mathrm{C} \ldots$ & 14.55 & 9 & 52 & .6154 & .2885 & .0384 & .0577 & $\mathrm{NS}$ \\
\hline $14 \mathrm{D}$. & 16.18 & 11 & 56 & .6428 & .2500 & .0536 & .0536 & NS \\
\hline $14 \mathrm{I}$. & 27.74 & 4 & 31 & .4516 & .3871 & .1613 & .0000 & NS \\
\hline $14 \mathrm{~J} \ldots$ & 35.64 & 8 & 50 & .3800 & .4800 & .1200 & .0200 & NS \\
\hline \multicolumn{9}{|l|}{ Thompson Seedless: } \\
\hline $14 \mathrm{E} \ldots$ & 7.19 & 10 & 60 & .8167 & .0667 & .1166 & .0000 & NS \\
\hline $14 \mathrm{~F}$. & 13.53 & 12 & 73 & .5068 & .3151 & .1233 & .0548 & NS \\
\hline $14 \mathrm{~K}$. & 15.47 & 8 & 57 & .6316 & .2281 & .1052 & .0351 & $\mathrm{Ns}$ \\
\hline $14 \mathrm{~L} \ldots$ & 21.67 & 5 & 42 & .2143 & .2619 & .3333 & .1905 & NS \\
\hline \multicolumn{9}{|l|}{ Perlette: } \\
\hline $15 \mathrm{~A}$. & 13.39 & 6 & 28 & .5000 & .2857 & .1786 & .0357 & NS \\
\hline $15 \mathrm{~B}$. & 17.05 & 7 & 35 & $.34 \angle 9$ & .3428 & .3143 & .0000 & NS \\
\hline $15 \mathrm{G} \ldots$ & 13.88 & 18 & 139 & .3669 & .2086 & .2230 & .2015 & * \\
\hline $15 \mathrm{H} \ldots$ & 16.78 & 14 & 100 & .2900 & .4500 & .1900 & .0700 & * \\
\hline \multicolumn{9}{|l|}{ Cardinal: } \\
\hline $15 \mathrm{C}$. & 17.42 & 9 & 52 & .4616 & .2692 & .2115 & .0577 & NS \\
\hline $15 \mathrm{D}$. & 18.14 & 11 & 57 & .2281 & .5088 & .1754 & .0877 & NS \\
\hline $15 \mathrm{I} \ldots$ & 28.36 & 4 & 31 & .1935 & .5161 & .2581 & .0323 & NS \\
\hline $15 \mathrm{~J} \ldots$ & 35.58 & 8 & 50 & .2800 & .5000 & .1800 & .0400 & NS \\
\hline \multicolumn{9}{|l|}{ Thompson Seedless: } \\
\hline $15 \mathrm{E}$ & 10.19 & 10 & 60 & .8167 & .1333 & .0333 & .0167 & $\mathrm{NS}$ \\
\hline $15 \mathrm{~F}$ & 15.66 & 12 & 73 & .3288 & .2740 & .3150 & .0822 & NS \\
\hline $15 \mathrm{~K}$. & 17.61 & 8 & 58 & .6379 & .1897 & .1724 & .0000 & NS \\
\hline $15 \mathrm{~L} \ldots$ & 23.33 & 5 & 42 & .0714 & .3333 & .4524 & .1429 & NS \\
\hline \multicolumn{9}{|l|}{ Perlette: } \\
\hline $16 \mathrm{~A}$. & 14.27 & 6 & 28 & .3571 & .2143 & .2857 & .1429 & NS \\
\hline $16 \mathrm{~B}$. & 18.26 & 7 & 35 & .2857 & .2286 & .3429 & .1428 & NS \\
\hline $16 \mathrm{G} \ldots$ & 18.43 & 18 & 139 & .1223 & .2374 & .3813 & .2590 & ** \\
\hline $16 \mathrm{H}$. & 18.75 & 14 & 102 & .0784 & .3922 & .4020 & .1274 & NS \\
\hline \multicolumn{9}{|l|}{ Cardinal: } \\
\hline $16 \mathrm{C}$. & 20.00 & 9 & 52 & .1731 & .4231 & .2692 & .1346 & * \\
\hline $16 \mathrm{D}$. & 20.51 & 11 & 56 & .1071 & .4822 & .2857 & .1250 & NS \\
\hline $16 \mathrm{I} .$. & 28.39 & 4 & $3 I$ & .1290 & .3871 & .3226 & .1613 & NS \\
\hline $16 \mathrm{~J} .$. & 36.14 & 8 & 50 & .1800 & .4600 & .2200 & .1400 & ** \\
\hline \multicolumn{9}{|l|}{ Thompson Seedless: } \\
\hline $16 \mathrm{E} \ldots \ldots \ldots \ldots$ & 12.06 & 10 & 60 & .5833 & .2000 & .2167 & .0000 & NS \\
\hline $16 \mathrm{~F} \ldots$ & 17.66 & 12 & 73 & .1781 & .4383 & .2329 & .1507 & NS \\
\hline $16 \mathrm{~K}$. & 21.00 & 8 & 58 & .3276 & .3620 & .1897 & .1207 & ** \\
\hline $16 \mathrm{~L}$. . & 28.03 & 5 & 42 & .0238 & .2857 & .4524 & .2381 & NS \\
\hline Perlette: & & & & & & & & \\
\hline $17 \mathrm{~A}$. & 15.73 & 6 & 28 & .2857 & .2143 & .3571 & .1429 & NS \\
\hline $17 \mathrm{~B}$. & 20.24 & 7 & 35 & .2286 & .1428 & .2000 & .4286 & NS \\
\hline 17 G. . & $22.78^{\circ}$ & 18 & 138 & .1812 & .3043 & .2536 & .2609 & $* *$ \\
\hline $17 \mathrm{H}$. & 23.01 & 14 & 101 & .0495 & .2376 & .5149 & .1980 & NS \\
\hline Cardinal: & & & & & & & & \\
\hline $17 \mathrm{C}$. . & 22.05 & 9 & 52 & .0385 & .4615 & .3269 & .1731 & • \\
\hline $17 \mathrm{D}$. & 22.44 & 11 & 57 & .1053 & .2456 & .4035 & .2456 & NS \\
\hline $17 \mathrm{I} .$. & 31.32 & 4 & 31 & .0000 & .2903 & .4194 & .2903 & NS \\
\hline $17 \mathrm{~J} \ldots$ & 39.55 & 8 & 50 & .0800 & .3200 & .3000 & .3000 & NS \\
\hline
\end{tabular}

*All categories based on the portion of the 5-point hedonic scale consistently used by each taster, as follows: $I=$ full range of five scores; II $=$ lowest four; $I I I=$ highest four; $I V=$ eentral three; $\mathrm{V}=$ highest three; $\mathrm{VI}=$ lowest three. $\dagger$ NS means not significant at the 5 per cent level. Single asterisk indicates some nonconformity. Double asterisks indicate more serious nonconformity. 
Appendix Table A-Continued

\begin{tabular}{|c|c|c|c|c|c|c|c|c|}
\hline \multicolumn{9}{|c|}{ Category II-Continued } \\
\hline \multirow{2}{*}{$\begin{array}{l}\text { Variety and } \\
\text { sample number }\end{array}$} & \multirow{2}{*}{$\begin{array}{l}\text { Balling/acid } \\
\text { ratio }\end{array}$} & \multirow{2}{*}{$\begin{array}{c}\text { Number } \\
\text { of } \\
\text { tasters }\end{array}$} & \multirow{2}{*}{$\begin{array}{c}\text { Number } \\
\text { of } \\
\text { tastings }\end{array}$} & \multicolumn{4}{|c|}{ Taste scale } & \multirow{2}{*}{$\begin{array}{l}\text { Signifi- } \\
\text { cance }\end{array}$} \\
\hline & & & & 1 & 2 & 3 & 4 & \\
\hline \multicolumn{9}{|l|}{ Thompson Seedless: } \\
\hline $17 \mathrm{E} \ldots \ldots \ldots \ldots$ & 13.46 & 10 & 60 & .3167 & .2833 & .2833 & .1167 & $*$ \\
\hline $17 \mathrm{~F} \ldots \ldots \ldots \ldots$ & 19.45 & 12 & 73 & .1370 & .2877 & .3150 & .2603 & NS \\
\hline $17 \mathrm{~K} \ldots \ldots \ldots$ & 21.52 & 8 & 58 & .1724 & .2414 & .2931 & .2931 & $* *$ \\
\hline $17 \mathrm{~L} \ldots \ldots \ldots \ldots$ & 31.25 & 5 & 42 & .0000 & .2143 & .3809 & 4048 & NS \\
\hline \multicolumn{9}{|l|}{ Perlette: } \\
\hline $18 \mathrm{~A} \ldots \ldots \ldots \ldots \ldots$ & 17.73 & 6 & 28 & .2500 & .0357 & .3929 & .3214 & NS \\
\hline $18 \mathrm{~B} \ldots \ldots \ldots \ldots \ldots \ldots$ & 22.50 & 7 & 35 & .1143 & .1143 & $.285 \pi$ & .4857 & NS \\
\hline $18 \mathrm{G} \ldots \ldots \ldots \ldots \ldots \ldots$ & 26.12 & 18 & 139 & .0791 & .2230 & .3022 & .3957 & $* *$ \\
\hline $18 \mathrm{H} \ldots \ldots \ldots \ldots \ldots$ & 25.36 & 14 & 102 & .0098 & .0980 & .3432 & .5490 & NS \\
\hline \multicolumn{9}{|l|}{ Cardinal: } \\
\hline $18 \mathrm{C} \ldots \ldots \ldots \ldots \ldots \ldots$ & 23.55 & 9 & 52 & .0769 & .1923 & .3846 & .3462 & NS \\
\hline $18 \mathrm{D} \ldots \ldots \ldots \ldots \ldots \ldots$ & 24.86 & 11 & 57 & .0175 & .2281 & .4211 & .3333 & NS \\
\hline $18 \mathrm{I} \ldots \ldots \ldots \ldots \ldots$ & 34.04 & 4 & 31 & .0000 & .1936 & .5161 & .2903 & NS \\
\hline $18 \mathrm{~J}, \ldots \ldots \ldots \ldots \ldots$ & 42.14 & 8 & 48 & .0417 & .2708 & .3750 & .3125 & NS \\
\hline \multicolumn{9}{|l|}{ Thompson Seedless: } \\
\hline $18 \mathrm{E} \ldots \ldots \ldots \ldots \ldots \ldots$ & 14.50 & 10 & 60 & .2167 & .3000 & .2166 & .2667 & $*$ \\
\hline $18 \mathrm{~F} \ldots \ldots \ldots \ldots \ldots \ldots$ & 21.76 & 12 & 73 & .1507 & .1096 & .3424 & .3973 & NS \\
\hline $18 \mathrm{~K} \ldots \ldots \ldots \ldots \ldots \ldots$ & 25.69 & 8 & 58 & .1034 & .1035 & .3621 & .4310 & $* *$ \\
\hline $18 \mathrm{~L}, \ldots \ldots \ldots \ldots \ldots \ldots$ & 33.04 & 5 & 42 & .0714 & .1191 & .5476 & 2619 & NS \\
\hline \multicolumn{9}{|l|}{ Perlette: } \\
\hline $19 \mathrm{~A} \ldots \ldots$ & 19.27 & 6 & 28 & .1786 & .1786 & .2857 & .3571 & NS \\
\hline $19 \mathrm{~B} \ldots \ldots$ & 23.85 & 7 & 35 & .0857 & .0857 & .4000 & .4286 & NS \\
\hline \multicolumn{9}{|l|}{ Cardinal: } \\
\hline $19 \mathrm{C} \ldots$ & 25.06 & 9 & 52 & ,.0192 & .1346 & .3269 & .5193 & NS \\
\hline $19 \mathrm{D} \ldots \ldots$ & 28.12 & 11 & 56 & .0179 & .1071 & .3393 & .5357 & NS \\
\hline $19 \mathrm{I} \ldots \ldots \ldots \ldots \ldots \ldots$ & 34.53 & 4 & 31 & .0000 & .0968 & .5161 & .3871 & NS \\
\hline $19 \mathrm{~J} \ldots \ldots \ldots \ldots \ldots \ldots$ & 46.92 & 8 & 50 & .0400 & .2600 & .3200 & .3800 & NS \\
\hline \multicolumn{9}{|l|}{ Thompson Seedless: } \\
\hline $19 \mathrm{E} \ldots \ldots \ldots \ldots \ldots \ldots$ & 16.12 & 10 & 59 & .0848 & .1864 & .3729 & .3559 & NS \\
\hline $19 \mathbf{F} \ldots \ldots \ldots \ldots \ldots \ldots$ & 24.87 & 12 & 72 & .0833 & .1667 & .3750 & .3750 & NS \\
\hline $19 \mathrm{~K} \ldots \ldots \ldots \ldots \ldots \ldots$ & 28.24 & 8 & 58 & .1207 & .1552 & .2241 & .5000 & $*$ \\
\hline $19 \mathrm{~L} \ldots \ldots \ldots \ldots \ldots \ldots$ & 35.27 & 5 & 42 & .0238 & .1429 & .1905 & .6428 & ** \\
\hline
\end{tabular}

* All categories based on the portion of the 5-point hedonic scale consistently used by each taster, as follows: $I=$ full range of five scores; II = lowest four; III = highest four; IV $=$ central three; $V=$ highest three; VI $=$ lowest three.

$\dagger$ NS means not significant at the 5 per cent level. Single asterisk indicates some nonconformity. Double asterisks indicate more serious nonconformity. 
Appendix Table A-Continued

\begin{tabular}{|c|c|c|c|c|c|c|c|c|}
\hline \multicolumn{9}{|c|}{ Category III* } \\
\hline \multirow{2}{*}{$\begin{array}{l}\text { Variety and } \\
\text { sample number }\end{array}$} & \multirow{2}{*}{$\underset{\text { ratio }}{\text { Balling/acid }}$} & \multirow{2}{*}{$\begin{array}{c}\text { Number } \\
\text { of } \\
\text { tasters }\end{array}$} & \multirow{2}{*}{$\begin{array}{c}\text { Number } \\
\text { of } \\
\text { tastings }\end{array}$} & \multicolumn{4}{|c|}{ Taste scale } & \multirow{2}{*}{$\begin{array}{l}\text { Signifi- } \\
\text { cance }\end{array}$} \\
\hline & & & & 2 & 3 & 4 & 5 & \\
\hline \multicolumn{8}{|l|}{ Perlette: } & NS \\
\hline \multicolumn{9}{|l|}{ Cardinal: } \\
\hline $14 \mathrm{I} \ldots$ & 27.74 & 11 & 60 & .4833 & .3000 & .2000 & .0167 & NS \\
\hline $14 \mathrm{~J} \ldots \ldots \ldots \ldots$ & 35.64 & 4 & 28 & .5357 & .1786 & .2500 & .0357 & NS \\
\hline \multicolumn{9}{|l|}{ 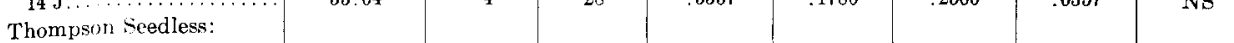 } \\
\hline $14 \mathrm{~F}$ & 13,53 & 3 & 17 & .4706 & .4706 & .0588 & .0000 & NS \\
\hline $14 \mathrm{~L}$. . & 21.67 & 14 & 113 & .4336 & .2920 & .1859 & .0885 & $* *$ \\
\hline \multicolumn{9}{|l|}{ Perlette: } \\
\hline $15 \mathrm{~B}$ & 17.05 & 2 & 9 & .2222 & .3333 & .3334 & .1111 & NS \\
\hline \multicolumn{9}{|l|}{ Cardinal: } \\
\hline $15 \mathrm{I} \ldots \ldots$ & 28.36 & 11 & 61 & .3770 & .3607 & 1803 & .0820 & NS \\
\hline $15 \mathrm{~J}$ & 35.58 & 4 & 28 & .3214 & .3214 & .3214 & .0358 & NS \\
\hline \multicolumn{9}{|l|}{ Thompson Seedless: } \\
\hline $15 \mathrm{~F} \ldots \ldots \ldots \ldots$ & 15.66 & 3 & 16 & .4375 & .2500 & .2500 & .0625 & * \\
\hline $15 \mathrm{~L} \ldots \ldots \ldots \ldots$ & 23.33 & 14 & 13 & .2655 & .3363 & .2124 & .1858 & * \\
\hline \multicolumn{9}{|l|}{ Perlette: } \\
\hline $16 \mathrm{~B} \ldots$ & 18.26 & 2 & 9 & .4445 & .2222 & .3333 & .0000 & NS \\
\hline \multicolumn{9}{|l|}{ Cardinal: } \\
\hline $16 \mathrm{I}$. & 28.39 & 11 & 58 & .1207 & .3103 & .4138 & .1552 & $* *$ \\
\hline $16 \mathrm{~J} \ldots \ldots \ldots \ldots \ldots$ & 36.14 & 4 & 27 & .2222 & .2963 & 4074 & .0741 & NS \\
\hline \multicolumn{9}{|l|}{ Thompson Seedless: } \\
\hline $16 \mathrm{~F} \ldots \ldots \ldots \ldots$ & 17.66 & 3 & 17 & .1176 & .1765 & .4706 & .2353 & NS \\
\hline $16 \mathrm{~L} \ldots$ & 28.03 & 14 & 111 & .1261 & .2883 & .3874 & .1982 & $* *$ \\
\hline \multicolumn{9}{|l|}{ Perlette: } \\
\hline $17 \mathrm{~B} \ldots$ & 20.24 & 2 & 9 & .2222 & .1111 & .5556 & .1111 & NS \\
\hline \multicolumn{9}{|l|}{ Cardinal: } \\
\hline $17 \mathrm{I} . .$. & 31.32 & 11 & 61 & .0820 & .3278 & .3115 & .2787 & NS \\
\hline $17 \mathrm{~J} \ldots$ & 39.55 & 4 & 28 & .0714 & .3214 & .3572 & .2500 & NS \\
\hline \multicolumn{9}{|l|}{ Thompson Seedless: } \\
\hline $17 \mathrm{~F} \ldots \ldots \ldots \ldots$ & 19.45 & 3 & 17 & .1765 & .2353 & .4706 & .1176 & NS \\
\hline $17 \mathrm{~L} \ldots \ldots \ldots \ldots$ & 31.25 & 14 & 112 & .0625 & .2411 & .3393 & 3571 & NS \\
\hline \multicolumn{9}{|l|}{ Perlette: } \\
\hline $18 \mathrm{~B}$. & 22.50 & 2 & 9 & .0000 & .0000 & .3333 & .6667 & NS \\
\hline Cardinal: & & & & & & & & \\
\hline $18 \mathrm{I}$. & 34.04 & 11 & 61 & .0328 & .1312 & .4590 & .3770 & NS \\
\hline $18 \mathrm{~J} \ldots \ldots$ & 42.14 & 4 & 28 & .1429 & .3214 & .4286 & .1071 & $\mathrm{NS}$ \\
\hline Thompson Seedless: & & & & & & & & \\
\hline $18 \mathrm{~F} \ldots$ & 21.76 & 3 & 17 & .0000 & .1176 & .5294 & .3530 & NS \\
\hline $18 \mathrm{~L} \ldots$ & 33.04 & 14 & 112 & .0357 & .0625 & .3214 & .5804 & $*$ \\
\hline Perlette: & & & & & & & & \\
\hline $19 \mathrm{~B}$. & 23.85 & 2 & 9 & .0000 & .1111 & .4445 & .4444 & NS \\
\hline Cardinal: & & & & & & & & \\
\hline $19 \mathrm{I}$. & 34.53 & 11 & 61 & .0000 & .0820 & .5082 & .4098 & NS \\
\hline $19 \mathrm{~J} \ldots$ & 46.92 & 4 & 27 & 0741 & .0741 & .5555 & .2963 & NS \\
\hline Thompson Seedless: & & & & & & & & \\
\hline $19 \mathrm{~F}$. & 24.87 & 3 & 17 & .0000 & .0588 & .5294 & .4118 & NS \\
\hline $19 \mathrm{~L}$ & 33.04 & 14 & 113 & .0354 & .0885 & .3274 & .5487 & $* *$ \\
\hline
\end{tabular}

*All categories based on the portion of the 5 -point hedonic scale consistently used by each taster, as follows: $\mathbf{I}=$ full range of five scores; II = Iowest four; III = highest four; IV $=$ central three; $V=$ highest three; VI $=$ lowest three. $\dagger$ NS means not significant at the 5 per cent level. Single asterisk indicates some nonconformity. Double asterisks indicate more serious nonconformity. 
Appendix Thale A-Continued

\begin{tabular}{|c|c|c|c|c|c|c|c|}
\hline \multicolumn{8}{|c|}{ Category IV* } \\
\hline \multirow{2}{*}{ Variety and sample number } & \multirow{2}{*}{$\begin{array}{l}\text { Balling/acid } \\
\quad \text { ratio }\end{array}$} & \multirow{2}{*}{$\begin{array}{c}\text { Number } \\
\text { of } \\
\text { tasters }\end{array}$} & \multirow{2}{*}{$\begin{array}{c}\text { Number } \\
\text { of } \\
\text { tastings }\end{array}$} & \multicolumn{3}{|c|}{ Taste scale } & \multirow{2}{*}{$\begin{array}{l}\text { Signifi- } \\
\text { cance }{ }^{-}\end{array}$} \\
\hline & & & & 2 & 3 & 4 & \\
\hline \multicolumn{8}{|l|}{ Perlette: } \\
\hline $14 \mathrm{H} \ldots$ & 14.34 & 2 & 9 & .5556 & .4444 & .0000 & NS \\
\hline \multicolumn{8}{|l|}{ Cardinal: } \\
\hline $14 \mathrm{C} \ldots$ & 14.55 & 6 & 26 & .6923 & .1923 & .11 .54 & $* *$ \\
\hline $14 \mathrm{D}$. & 16.18 & 5 & 24 & .7083 & .1667 & .1250 & NS \\
\hline $14 \mathrm{I} \ldots$ & 27.74 & 2 & 14 & .3572 & .0714 & .5714 & NS \\
\hline $14 \mathrm{~J} \ldots$ & 35.64 & 2 & 10 & .8000 & .2000 & .0000 & NS \\
\hline \multicolumn{8}{|l|}{ Thompson Seedless: } \\
\hline $14 \mathrm{~F}$ & 13.53 & 2 & 11 & .5455 & .3636 & .0909 & $\mathrm{NS}$ \\
\hline $14 \mathrm{~K} \ldots$ & 15.47 & 3 & 26 & .4615 & .5000 & .0385 & NS \\
\hline $14 \mathrm{~L} \ldots$ & 21.67 & 4 & 23 & .5217 & .3913 & .0870 & NS \\
\hline \multicolumn{8}{|l|}{ Perlette: } \\
\hline $15 \mathrm{H}$ & 16.78 & 2 & 9 & .2222 & .5556 & .2222 & NS \\
\hline \multicolumn{8}{|l|}{ Cardinal: } \\
\hline $15 \mathrm{C} \ldots$ & 17.42 & 6 & 26 & .5000 & .3462 & .1538 & NS \\
\hline $15 \mathrm{D} \ldots \ldots$ & 18.14 & 5 & 24 & .3333 & .3334 & .3333 & $*$ \\
\hline $15 \mathrm{I} \ldots \ldots$ & 28.36 & 2 & 14 & .1429 & .3571 & .5000 & NS \\
\hline $15 \mathrm{~J} \ldots \ldots \ldots \ldots \ldots \ldots \ldots$ & 35.58 & 2 & 10 & .7000 & .3000 & .0000 & NS \\
\hline \multicolumn{8}{|l|}{ Thompson Seedless: } \\
\hline $15 \mathrm{~F} \ldots \ldots$ & 15.66 & 2 & 11 & .3636 & .5455 & .0909 & NS \\
\hline $15 \mathrm{~K} \ldots$ & 17.61 & 3 & 26 & .3077 & .5769 & .1154 & NS \\
\hline $15 \mathrm{~L} \ldots \ldots \ldots \ldots \ldots \ldots \ldots$ & 23.33 & 4 & 23 & .3478 & .5652 & .0870 & NS \\
\hline \multicolumn{8}{|l|}{ Perlette: } \\
\hline $16 \mathrm{H}$ & 18.75 & 2 & 9 & .2222 & .5556 & .2222 & $\mathrm{NS}$ \\
\hline \multicolumn{8}{|l|}{ Cardinal: } \\
\hline $16 \mathrm{C} \ldots$ & 20.00 & 6 & 26 & .3077 & .3077 & .3846 & NS \\
\hline $16 \mathrm{D} \ldots \ldots \ldots \ldots \ldots$ & 20.51 & 5 & 24 & .3333 & .3334 & .3333 & $*$ \\
\hline $16 \mathrm{I} \ldots \ldots$ & 28.39 & 2 & 14 & .2143 & .4286 & .3571 & NS \\
\hline $16 \mathrm{~J} \ldots \ldots$ & 36.14 & 2 & 9 & .6667 & .3333 & .0000 & NS \\
\hline \multicolumn{8}{|l|}{ Thompson Seedless: } \\
\hline $16 \mathrm{~F} \ldots \ldots \ldots \ldots \ldots$ & 17.66 & 2 & 11 & .1818 & .5455 & .2727 & NS \\
\hline $16 \mathrm{~K} \ldots \ldots \ldots \ldots \ldots \ldots \ldots$ & 21.00 & 3 & 26 & .3846 & .5000 & .1154 & NS \\
\hline $16 \mathrm{~L}, \ldots \ldots \ldots \ldots \ldots$ & 28.03 & 4 & 23 & .1739 & .4783 & .3478 & NS \\
\hline \multicolumn{8}{|l|}{ Perlette: } \\
\hline $17 \mathrm{H} \ldots$ & 23.01 & 2 & 9 & .1111 & .5556 & .3333 & NS \\
\hline \multicolumn{8}{|l|}{ Cardinal: } \\
\hline $17 \mathrm{C} \ldots$ & 22.05 & 6 & 26 & .1539 & .3846 & .4615 & * \\
\hline $17 \mathrm{D} \ldots \ldots \ldots \ldots \ldots \ldots \ldots$ & 22.44 & 5 & 24 & .2917 & .3333 & .3750 & NS \\
\hline $17 \mathrm{I} \ldots \ldots \ldots \ldots \ldots \ldots \ldots \ldots$ & 31.32 & 2 & 14 & .2143 & .5714 & .2143 & NS \\
\hline $17 \mathrm{~J} \ldots \ldots \ldots \ldots \ldots \ldots \ldots \ldots$ & 39.55 & 2 & 10 & .3000 & .6000 & .1000 & NS \\
\hline \multicolumn{8}{|l|}{ Thompson Seedless: } \\
\hline $17 \mathbf{F} \ldots \ldots$ & 19.45 & 2 & 11 & .0909 & .8182 & .0909 & NS \\
\hline $17 \mathrm{~K} \ldots$ & 21.52 & 3 & 26 & .1538 & .5385 & .3077 & NS \\
\hline $17 \mathrm{~L} \ldots \ldots$ & 31.25 & 4 & 23 & .1304 & .4783 & .3913 & NS \\
\hline \multicolumn{8}{|l|}{ Perlette: } \\
\hline $18 \mathrm{H} . \ldots$ & 25.36 & 2 & 9 & .0000 & .4444 & .5556 & NS \\
\hline
\end{tabular}

* All categories based on the portion of the 5-point hedonic scale consistently used by each taster, as follows: $\mathrm{I}=$ full range of five scores; II $=$ lowest four; III $=$ highest four; IV $=$ central three; $\mathrm{V}=$ highest three; $V I=$ lowest three.

$\div$ NS means not significant at the 5 per cent ievel. Single asterisk indicates some nonconformity. Double asterisks indicate more serious nonconformity. 
Appendix Table A-Continued

\begin{tabular}{|c|c|c|c|c|c|c|c|}
\hline \multicolumn{8}{|c|}{ Category IV-Continued } \\
\hline \multirow{2}{*}{ Variety and sample number } & \multirow{2}{*}{$\begin{array}{l}\text { Balling/acid } \\
\text { ratio }\end{array}$} & \multirow{2}{*}{$\begin{array}{c}\text { Number } \\
\text { of } \\
\text { tasters }\end{array}$} & \multirow{2}{*}{$\begin{array}{l}\text { Number } \\
\text { of } \\
\text { tastings }\end{array}$} & \multicolumn{3}{|c|}{ Taste scale } & \multirow{2}{*}{$\begin{array}{l}\text { Signifi- } \\
\text { cancet }\end{array}$} \\
\hline & & & & 2 & 3 & 4 & \\
\hline \multicolumn{8}{|l|}{ Cardinal: } \\
\hline $18 \mathrm{C} \ldots \ldots$ & 23.55 & 6 & 26 & .1154 & .2308 & .6538 & NS \\
\hline $18 \mathrm{D} \ldots$ & 24.86 & 5 & 24 & .1250 & 4167 & .4583 & NS \\
\hline $18 \mathrm{I} \ldots$ & 34.04 & 2 & 14 & .1429 & .7143 & .1428 & NS \\
\hline $18 \mathrm{~J} \ldots \ldots \ldots \ldots \ldots$ & 42.14 & 2 & 10 & .1000 & .5000 & .4000 & NS \\
\hline \multicolumn{8}{|l|}{ Thompson Seedless: } \\
\hline $18 \mathrm{~F} \ldots \ldots \ldots$ & 21.76 & 2 & 11 & .0909 & .3636 & .5455 & NS \\
\hline $18 \mathrm{~K} \ldots \ldots \ldots \ldots$ & 25.69 & 3 & 26 & .1539 & .4615 & .3846 & $*$ \\
\hline $18 \mathrm{~L} \ldots \ldots \ldots$ & 33.04 & 4 & 23 & .0000 & .3043 & .6957 & NS \\
\hline \multicolumn{8}{|l|}{ Cardinal: } \\
\hline $19 \mathrm{C} \ldots$ & 25.06 & 6 & 26 & .0000 & .4231 & .5769 & NS \\
\hline $19 \mathrm{D} \ldots$ & 28.12 & 5 & 24 & .1667 & .3333 & .5000 & NS \\
\hline $19 \mathrm{I} \ldots \ldots \ldots \ldots \ldots$ & 34.53 & 2 & 14 & .1429 & .8571 & .0000 & NS \\
\hline $10 \mathrm{~J} \ldots \ldots \ldots \ldots \ldots \ldots$ & 46.92 & 2 & 10 & .2000 & .1000 & .7000 & NS \\
\hline \multicolumn{8}{|l|}{ Thompson Seedless: } \\
\hline $19 \mathbf{F} \ldots \ldots \ldots \ldots \ldots \ldots \ldots$ & 24.87 & 2 & 11 & .0000 & .3636 & .6364 & NS \\
\hline $19 \mathrm{~K}, \ldots \ldots \ldots \ldots \ldots \ldots \ldots$ & 28.24 & 3 & 26 & .1154 & .5769 & .3077 & NS \\
\hline $19 \mathrm{~L} \ldots \ldots \ldots \ldots \ldots \ldots \ldots$ & 35.27 & 4 & 22 & .0000 & .3182 & .6818 & NS \\
\hline
\end{tabular}

* All categories based on the portion of the 5-point hedonic scale consistently used by each taster, as follows: $I=$ full range of five scores; II $=$ lowest four; III = highest four; IV = central three; $V=$ highest three; VI $=$ lowest three. $\dagger$ NS means not significant at the 5 per cent level. Single asterisk indicates some nonconformity. Double asterisks indicate more serious nonconformity. 
Appendix Thale A-Continued

\begin{tabular}{|c|c|c|c|c|c|c|c|}
\hline \multicolumn{8}{|c|}{ Category $\mathrm{V}$} \\
\hline \multirow{2}{*}{ Variety and sample number } & \multirow{2}{*}{$\begin{array}{l}\text { 13alling/acid } \\
\text { ratio }\end{array}$} & \multirow{2}{*}{$\begin{array}{c}\text { Number } \\
\text { of } \\
\text { tasters }\end{array}$} & \multirow{2}{*}{$\begin{array}{c}\text { Number } \\
\text { of } \\
\text { tastings }\end{array}$} & \multicolumn{3}{|c|}{ Taste scale } & \multirow{2}{*}{$\begin{array}{l}\text { Signifi- } \\
\text { cancet }\end{array}$} \\
\hline & & & & 3 & 4 & 5 & \\
\hline \multicolumn{8}{|l|}{ Cardinal: } \\
\hline $14 \mathrm{C} \ldots$ & 14.55 & 3 & 15 & .7333 & .2667 & .0000 & NS \\
\hline $14 \mathrm{D} \ldots$ & 16.18 & 2 & 11 & .6364 & .3636 & .0000 & NS \\
\hline $14 \mathrm{I} \ldots \ldots$ & 27.74 & 5 & 33 & .3939 & .5152 & .0909 & $*$ \\
\hline $14 \mathrm{~J} \ldots \ldots \ldots \ldots \ldots \ldots \ldots$ & 35.64 & 5 & 26 & .7308 & .2692 & .0000 & NS \\
\hline \multicolumn{8}{|l|}{ Cardinal: } \\
\hline $15 \mathrm{C} \ldots$ & 17.42 & 3 & 15 & .4667 & .4000 & .1333 & NS \\
\hline $15 \mathrm{D} \ldots$ & 18.14 & 2 & 11 & .3636 & .4546 & .1818 & NS \\
\hline $15 \mathrm{I} \ldots \ldots$ & 28.36 & 5 & 33 & .3940 & .3636 & .2424 & $* *$ \\
\hline $15 \mathrm{~J} \ldots \ldots$ & 35.58 & 5 & 26 & .4615 & .4615 & .0770 & NS \\
\hline \multicolumn{8}{|l|}{ Cardinal: } \\
\hline $16 \mathrm{C} \ldots$ & 20.00 & 3 & 15 & .0667 & .9333 & .0000 & NS \\
\hline $16 \mathrm{D} \ldots$ & 20.51 & 2 & 11 & .1818 & .6364 & .1818 & NS \\
\hline $16 \mathrm{I} \ldots \ldots$ & 28.39 & 5 & 33 & .2121 & .5455 & .2424 & NS \\
\hline $16 \mathrm{~J} \ldots \ldots$ & 36.14 & 5 & 26 & .3077 & .6154 & .0769 & NS \\
\hline \multicolumn{8}{|l|}{ Cardinal: } \\
\hline $17 \mathrm{C} \ldots$ & 22.05 & 3 & 15 & .1333 & .4667 & .4000 & NS \\
\hline $17 \mathrm{D} \ldots \ldots \ldots \ldots \ldots \ldots$ & 22.44 & 2 & 10 & .2000 & .5000 & .3000 & NS \\
\hline $17 \mathrm{I} \ldots \ldots \ldots \ldots \ldots \ldots$ & 31.32 & 5 & 32 & .0937 & .5625 & .3438 & NS \\
\hline $17 \mathrm{~J} \ldots \ldots$ & 39.55 & 5 & 26 & .1538 & .6539 & .1923 & NS \\
\hline \multicolumn{8}{|l|}{ Cardinal: } \\
\hline $18 \mathrm{C} \ldots$ & 23.55 & 3 & 15 & .1333 & .4667 & .4000 & NS \\
\hline $18 \mathrm{D} \ldots$ & 24.86 & 2 & 11 & .0000 & .6364 & .3636 & NS \\
\hline $18 \mathrm{I} \ldots$. & 34.04 & 5 & 33 & .1515 & .4546 & .3939 & NS \\
\hline $18 \mathrm{~J} \ldots \ldots \ldots \ldots \ldots \ldots$ & 42.14 & 5 & 26 & .1154 & .5769 & .3077 & NS \\
\hline \multicolumn{8}{|l|}{ Cardinal: } \\
\hline $19 \mathrm{C} \ldots \ldots \ldots$ & 25,06 & 3 & 15 & .0667 & .6000 & .3333 & NS \\
\hline $19 \mathrm{D} \ldots \ldots \ldots$ & 28.12 & 2 & 11 & .0000 & .6364 & .3636 & NS \\
\hline $19 \mathrm{I} \ldots \ldots \ldots \ldots \ldots \ldots$ & 34.53 & 5 & 33 & .1515 & .3333 & .5152 & NS \\
\hline $19 \mathrm{~J} \ldots \ldots \ldots \ldots \ldots \ldots \ldots \ldots \ldots \ldots \ldots \ldots$ & 46.92 & 5 & 26 & .0384 & .4231 & .5385 & NS \\
\hline
\end{tabular}

* All categories based on the portion of the 5-point hedonic scale consistently used by each taster, as follows: $I=$ full range of five scores; II = lowest four; III = highest four; IV = central three; V = highest three; VI = lowest three. $+\mathrm{NS}$ means not significant at the 5 per cent level. Single asterisk indicates some nonconformity. Double asterisks indicate more serious nonconformity. 
Appendix Table A-Continued

\begin{tabular}{|c|c|c|c|c|c|c|c|}
\hline \multicolumn{8}{|c|}{ Category VI } \\
\hline \multirow{2}{*}{ Variety and sample number } & \multirow{2}{*}{$\begin{array}{l}\text { Balling/acid } \\
\text { ratio }\end{array}$} & \multirow{2}{*}{$\begin{array}{c}\text { Number } \\
\text { of } \\
\text { tasters }\end{array}$} & \multirow{2}{*}{$\begin{array}{c}\text { Number } \\
\text { of } \\
\text { tastings }\end{array}$} & \multicolumn{3}{|c|}{ Taste scale } & \multirow{2}{*}{$\begin{array}{l}\text { Signifi- } \\
\text { cancet }\end{array}$} \\
\hline & & & & 1 & 2 & 3 & \\
\hline \multicolumn{8}{|l|}{ Perlette: } \\
\hline $14 \mathrm{~A} \ldots$ & 12.28 & 2 & 48 & .8125 & .1458 & .0417 & NS \\
\hline $14 \mathrm{~B} \ldots \ldots \ldots \ldots \ldots$ & 14.95 & 8 & 32 & .7500 & .2500 & .0000 & NS \\
\hline $14 \mathrm{G} \ldots$ & 9.70 & 6 & 32 & .8750 & .1250 & .0000 & NS \\
\hline $14 \mathrm{H} \ldots \ldots \ldots \ldots \ldots \ldots \ldots$ & 14.34 & 3 & 21 & .6667 & .2381 & .0952 & $*$ \\
\hline \multicolumn{8}{|l|}{ Cardinal: } \\
\hline$\ldots \ldots \ldots \ldots \ldots$ & 14.55 & 6 & 27 & .8519 & .1111 & .0370 & NS \\
\hline $14 \mathrm{D} \ldots \ldots \ldots \ldots \ldots \ldots \ldots$ & 16.18 & 3 & 13 & .7692 & .2308 & .0000 & NS \\
\hline $14 \mathrm{I} \ldots \ldots \ldots \ldots \ldots \ldots \ldots$ & 27.74 & 2 & 10 & .7000 & .2000 & .1000 & NS \\
\hline \multirow{2}{*}{\multicolumn{8}{|c|}{ Thompson Seedless: }} \\
\hline & & & & & & & \\
\hline $14 \mathrm{E} \ldots$ & 7.19 & 12 & 60 & .8167 & .1667 & .0166 & $* *$ \\
\hline $14 \mathrm{~F} \ldots \ldots \ldots \ldots \ldots$ & 13.53 & $i$ & 21 & .6667 & .2381 & .0952 & NS \\
\hline $14 \mathrm{~K} \ldots \ldots \ldots \ldots \ldots \ldots \ldots$ & 15.47 & 5 & 26 & 6923 & .2692 & .0385 & $*$ \\
\hline \multicolumn{8}{|l|}{ Perlette: } \\
\hline $15 \mathrm{~A} \ldots \ldots \ldots \ldots \ldots \ldots \ldots$ & 13.39 & 2 & 54 & .7408 & .2407 & .0185 & NS \\
\hline $15 \mathrm{~B} \ldots \ldots \ldots \ldots \ldots \ldots \ldots$ & 17.05 & 8 & 35 & .6000 & .3714 & .0286 & NS \\
\hline $15 \mathrm{G} \ldots \ldots \ldots \ldots$ & 13.88 & 6 & 33 & .5758 & .3030 & .1212 & NS \\
\hline $15 \mathrm{H} \ldots \ldots \ldots \ldots$ & 16.78 & 3 & 21 & .4286 & .3333 & .2381 & NS \\
\hline \multicolumn{8}{|l|}{ Cardinal: } \\
\hline $15 \mathrm{C} \ldots$ & 17.42 & 6 & 27 & .5556 & .4074 & .0370 & NS \\
\hline $15 \mathrm{D} \ldots \ldots$ & 18.14 & 3 & 13 & .5385 & .3846 & .0769 & NS \\
\hline $15 \mathrm{I}, \ldots \ldots \ldots \ldots \ldots \ldots$ & 28.36 & 2 & 10 & .3000 & .5000 & .2000 & NS \\
\hline $15 \mathrm{~J} \ldots \ldots \ldots \ldots \ldots \ldots \ldots$ & 35.58 & 4 & 27 & .4815 & .4074 & .1111 & NS \\
\hline \multicolumn{8}{|l|}{ Thompson Seedless: } \\
\hline $15 \mathrm{E} \ldots$ & 10.19 & 12 & 59 & .7797 & .2034 & .0169 & $*$ \\
\hline $15 \mathrm{~F} \ldots \ldots \ldots \ldots \ldots \ldots \ldots$ & 15.66 & 7 & 21 & .5238 & .3333 & .1429 & NS \\
\hline $15 \mathrm{~K}, \ldots \ldots \ldots \ldots \ldots$ & 17.61 & 5 & 27 & .6667 & .2592 & .0741 & NS \\
\hline \multicolumn{8}{|l|}{ Perlette: } \\
\hline $16 \mathrm{~A} \ldots \ldots \ldots \ldots$ & 14.27 & 2 & 54 & .5370 & .4259 & .0371 & NS \\
\hline $16 \mathrm{~B} \ldots \ldots \ldots \ldots \ldots$ & 18.26 & 8 & 35 & .4286 & .2857 & .2857 & NS \\
\hline $16 \mathrm{G} \ldots \ldots \ldots \ldots \ldots$ & 18.43 & 6 & 33 & .2727 & .3940 & .3333 & NS \\
\hline $16 \mathrm{H} \ldots \ldots \ldots \ldots \ldots$ & 18.75 & 3 & 21 & .1428 & .6667 & .1905 & NS \\
\hline \multicolumn{8}{|l|}{ Cardinal: } \\
\hline $16 \mathrm{C} \ldots$ & 20.00 & 6 & 27 & .4074 & .3704 & .2222 & NS \\
\hline $16 \mathrm{D} \ldots \ldots \ldots \ldots \ldots \ldots$ & 20.51 & 3 & 13 & .3077 & .3846 & .3077 & NS \\
\hline $161 \ldots \ldots \ldots \ldots \ldots \ldots \ldots \ldots$ & 28.39 & 2 & 10 & .1000 & .5000 & .4000 & NS \\
\hline $16 \mathrm{~J} \ldots \ldots \ldots \ldots \ldots \ldots \ldots$ & 36.14 & 4 & 27 & .2222 & .4445 & .3333 & NS \\
\hline \multicolumn{8}{|l|}{ Thompson Seedless: } \\
\hline $16 \mathrm{E} \ldots \ldots \ldots \ldots$ & 12.06 & 12 & 60 & .7000 & .2000 & .1000 & NS \\
\hline $16 \mathrm{~F} \ldots \ldots \ldots \ldots \ldots \ldots \ldots$ & 17.66 & 7 & 21 & .2381 & .4762 & .2857 & $*$ \\
\hline $16 \mathrm{~K} \ldots \ldots \ldots \ldots \ldots \ldots \ldots$ & 21.00 & 5 & 27 & .4074 & .5185 & .0741 & NS \\
\hline Perlette: & & & & & & & \\
\hline $17 \mathrm{~A} \ldots \ldots \ldots \ldots \ldots \ldots \ldots$ & 15.73 & 2 & 53 & .4717 & .3019 & .2264 & NS \\
\hline $17 \mathrm{~B} \ldots \ldots \ldots \ldots \ldots \ldots$ & 20.24 & 8 & 35 & .2571 & .4572 & .2857 & NS \\
\hline $17 \mathrm{G} \ldots \ldots \ldots \ldots \ldots \ldots \ldots$ & 22.78 & 6 & 32 & .0938 & .5000 & .4062 & NS \\
\hline $17 \mathrm{H} \ldots \ldots \ldots \ldots \ldots \ldots \ldots$ & 23.01 & 3 & 21 & .0476 & .5714 & .3810 & NS \\
\hline Cardinal: & & & & & & & \\
\hline $17 \mathrm{C} \ldots$ & 22.05 & 6 & 27 & .0370 & .6297 & .3333 & NS \\
\hline $17 \mathrm{D} \ldots \ldots \ldots \ldots \ldots \ldots$ & 22.44 & 3 & 13 & .3077 & .4615 & .2308 & NS \\
\hline $17 \mathrm{I} \ldots \ldots \ldots \ldots \ldots \ldots \ldots$ & 31.32 & 2 & 10 & .0000 & .6000 & .4000 & NS \\
\hline $17 \mathrm{~J} \ldots \ldots \ldots \ldots \ldots$ & 39.55 & 4 & 27 & .0741 & .2592 & .6667 & NS \\
\hline Thompson Seedless: & & & & & & & \\
\hline $17 \mathrm{E} \ldots \ldots \ldots \ldots$ & 13.46 & 12 & 60 & .4333 & .3667 & .2000 & * \\
\hline $17 \mathbf{F} \ldots \ldots \ldots \ldots$ & 19.45 & 7 & 21 & .1905 & .7619 & .0476 & NS \\
\hline $17 \mathrm{~K} \ldots \ldots \ldots \ldots \ldots \ldots$ & 21.52 & 5 & 27 & .1852 & .3704 & .4444 & NS \\
\hline
\end{tabular}

* All categories based on the portion of the 5-point hedonic scale consistently used by each taster, as follows: $I=$ full range of five scores; II $=$ lowest four; III $=$ highest four; IV $=$ central three; V $=\mathrm{highest}$ three;

$\mathrm{I}=$ lowest three.
$\dot{\dagger}$ NS means not significant at the 5 per cent level. Single asterisk inicates some noneonformity. Double asterisks indicate more serious nonconformity. 
Appendix Table A-Continued

\begin{tabular}{|c|c|c|c|c|c|c|c|}
\hline \multicolumn{8}{|c|}{ Category VI-Continued } \\
\hline \multirow{2}{*}{ Variety and sample number } & \multirow{2}{*}{$\underset{\text { ratio }}{\text { Balling/acid }}$} & \multirow{2}{*}{$\begin{array}{c}\text { Number } \\
\text { of } \\
\text { tasters }\end{array}$} & \multirow{2}{*}{$\begin{array}{c}\text { Number } \\
\text { of } \\
\text { tastings }\end{array}$} & \multicolumn{3}{|c|}{ Taste scale } & \multirow{2}{*}{$\begin{array}{l}\text { Signifi- } \\
\text { cancet }\end{array}$} \\
\hline & & & & 1 & 2 & 3 & \\
\hline \multicolumn{8}{|l|}{ Perlette: } \\
\hline $18 \mathrm{~A} \ldots$ & 17.73 & 2 & 54 & .2037 & .3704 & .4259 & NS \\
\hline $18 \mathrm{~B}, \ldots \ldots \ldots \ldots \ldots$ & 22.50 & 8 & 34 & .1176 & .4118 & .4706 & NS \\
\hline $18 \mathrm{G} \ldots \ldots \ldots \ldots \ldots \ldots \ldots$ & 26.12 & 6 & 33 & .0606 & .3333 & .6061 & $* *$ \\
\hline $18 \mathrm{H} \ldots \ldots \ldots \ldots \ldots \ldots \ldots$ & 25.36 & 3 & 21 & .0476 & .5238 & .4286 & NS \\
\hline \multicolumn{8}{|l|}{ Cardinal: } \\
\hline $18 \mathrm{C} \ldots \ldots \ldots \ldots \ldots$ & 23.55 & 6 & 27 & .0741 & .2963 & .6296 & NS \\
\hline $18 \mathrm{D} \ldots \ldots \ldots \ldots$ & 24.86 & 3 & 13 & .0769 & .5385 & .3846 & NS \\
\hline $18 \mathrm{I} \ldots \ldots \ldots \ldots \ldots \ldots$ & 34.04 & 2 & 10 & .1000 & .2000 & .7000 & NS \\
\hline $18 \mathrm{~J} \ldots \ldots \ldots \ldots \ldots \ldots \ldots$ & 42.14 & 4 & 27 & .1852 & .4074 & .4074 & NS \\
\hline \multicolumn{8}{|l|}{ Thompson Seedless: } \\
\hline $18 \mathrm{E} \ldots \ldots \ldots \ldots$ & 14.50 & 12 & 80 & .1500 & .5000 & .3500 & NS \\
\hline $18 \mathrm{~F} \ldots$. & 21.76 & 7 & 21 & .0476 & .5238 & .4286 & NS \\
\hline $18 \mathrm{~K} \ldots \ldots$ & $\mathbf{2 5 . 6 9}$ & 5 & 27 & .1111 & .4815 & .4074 & NS \\
\hline \multicolumn{8}{|l|}{ Perlette: } \\
\hline $19 \mathrm{~A} \ldots \ldots \ldots \ldots$ & 19.27 & 2 & 54 & .1481 & .4630 & .3889 & NS \\
\hline $19 \mathrm{~B} \ldots \ldots \ldots \ldots \ldots$ & 23.85 & 8 & 35 & .0857 & .3143 & .6000 & NS \\
\hline \multicolumn{8}{|l|}{ Cardinal: } \\
\hline $19 \mathrm{C} \ldots \ldots$ & 25.06 & 6 & 27 & .1111 & .2592 & .6297 & NS \\
\hline $19 \mathrm{D} \ldots \ldots$ & 28.12 & 3 & 13 & .1538 & .5385 & .3077 & NS \\
\hline $19 \mathrm{I} \ldots \ldots \ldots \ldots \ldots$ & 34.53 & 2 & 10 & .0000 & .2000 & .8000 & NS \\
\hline $19 \mathrm{~J}, \ldots \ldots \ldots \ldots \ldots$ & 46.92 & 4 & 27 & .1111 & .2222 & .6667 & * \\
\hline \multicolumn{8}{|l|}{ Thompson Seedless: } \\
\hline $19 \mathrm{E} \ldots \ldots \ldots \ldots$ & 16.12 & 12 & 60 & .1667 & .2667 & .5666 & NS \\
\hline $19 \mathrm{~F} \ldots$ & 24.87 & 7 & 21 & .0476 & .4286 & .5238 & NS \\
\hline $19 \mathrm{~K} \ldots \ldots \ldots \ldots \ldots \ldots \ldots \ldots$ & 28.24 & 5 & 27 & .0370 & .1852 & .7778 & NS \\
\hline
\end{tabular}

* All categories based on the portion of the 5-point hedonic scale consistently used by each taster, as follows: $I=$ full range of five scores; II $=$ lowest four; III = highest four; IV $=$ central three; $\mathrm{V}=$ highest three; VI $=$ lowest three. † NS means not significant at the 5 per cent level. Single asterisk indicates some nonconformity. Double asterisks indicate more serious nonconformity. 